\title{
A CISTERNA DE MONTE MOLIÃO (LAGOS, PORTUGAL)
}

THE MONTE MOLIÃO CISTERN (LAGOS, PORTUGAL)

\author{
FRANCISCO B. GOMES \\ UNIARQ - Centro de Arqueologia da Universidade de Lisboa; Faculdade de Letras da Universidade de Lisboa; \\ Fundação para a Ciência e Tecnologia. UNIARQ - Centro de Arqueologia da Universidade de Lisboa, Faculdade de Letras \\ da Universidade de Lisboa, Alameda da Universidade, 1600-214 Lisboa. \\ Correo electrónico: franciscojbgomes@gmail.com. (D) http://orcid.org/0000-0003-0664-6374 \\ CARLOS PEREIRA \\ UNIARQ - Centro de Arqueologia da Universidade de Lisboa; Faculdade de Letras da Universidade de Lisboa; \\ Fundação para a Ciência e Tecnologia. Dirección: UNIARQ - Centro de Arqueologia da Universidade de Lisboa. Faculdade de Letras \\ da Universidade de Lisboa. Alameda da Universidade, 1600-214, Lisboa. \\ Correo electrónico: carlos_samuel_pereira@hotmail.com. D https://orcid.org/0000-0002-4116-3602$$
\text { ANA MARGARIDA ARRUDA }
$$ \\ UNIARQ - Centro de Arqueologia da Universidade de Lisboa; Faculdade de Letras da Universidade de Lisboa. \\ Dirección: UNIARQ - Centro de Arqueologia da Universidade de Lisboa. Faculdade de Letras da Universidade de Lisboa. \\ Alameda da Universidade, 1600-214, Lisboa. \\ Correo electrónico: a.m.arruda@letras.ulisboa.pt. (D) https://orcid.org/0000-0002-7446-1104
}

Resumo: Conhecida desde o século XIX, a cisterna de Monte Molião constitui o elemento arquitectónico mais destacado do sítio e o único equipamento putativamente público ali documentado até ao momento. A sua escavação em 2011 e 2014 permitiu obter importantes dados sobre a sua tipologia e as técnicas empregues na sua construção, bem como documentar a estratigrafia correspondente à sua colmatação. Foi assim possível determinar que esta estrutura corresponde ao modelo dito a bagnarola, de origem púnica, podendo datar-se do final da Idade do Ferro ou de Época Romana Republicana, tendo sido sujeita a reparações durante este último período. Por outro lado, o último período de utilização desta cisterna parece ter-se verificado entre o Principado de Augusto e o reinado de Tibério, seguindo-se um período de abandono e o seu eventual entulhamento, datado pelos materiais aqui estudados da segunda metade do século I.

Palavras-chave: estruturas hidráulicas; Algarve; época romana; arquitectura púnica; arquitectura pública.
Abstract: Known since the $19^{\text {th }}$ century, the cistern of Monte
Molião is the most notable architectural element in the site
and the only likely public infrastructure identified so far in
this settlement. Its excavation, undertaken in 2011 and 2014 ,
has brought to light important data about its typology and
construction techniques; a complete stratigraphic sequence
corresponding to its filling has also been documented. This
structure can be attributed to the so-called a bagnarola model
which originated in the Punic world and could have been con-
structed either in the Late Iron Age or in the Roman Republi-
can period, having also been repaired in the latter period. Its
last period of use, on the other hand, seems to fall within the
reign of Augustus or Tiberius, being followed by a period of
abandonment and eventually by its intentional filling which,
based on the material studied here, can be dated to the second
half of the $1^{\text {st }}$ century.
Key words: hydraulic structures; Algarve; Roman times; PuKey words: hydraulic structures; Algar
nic architecture; public architecture. 


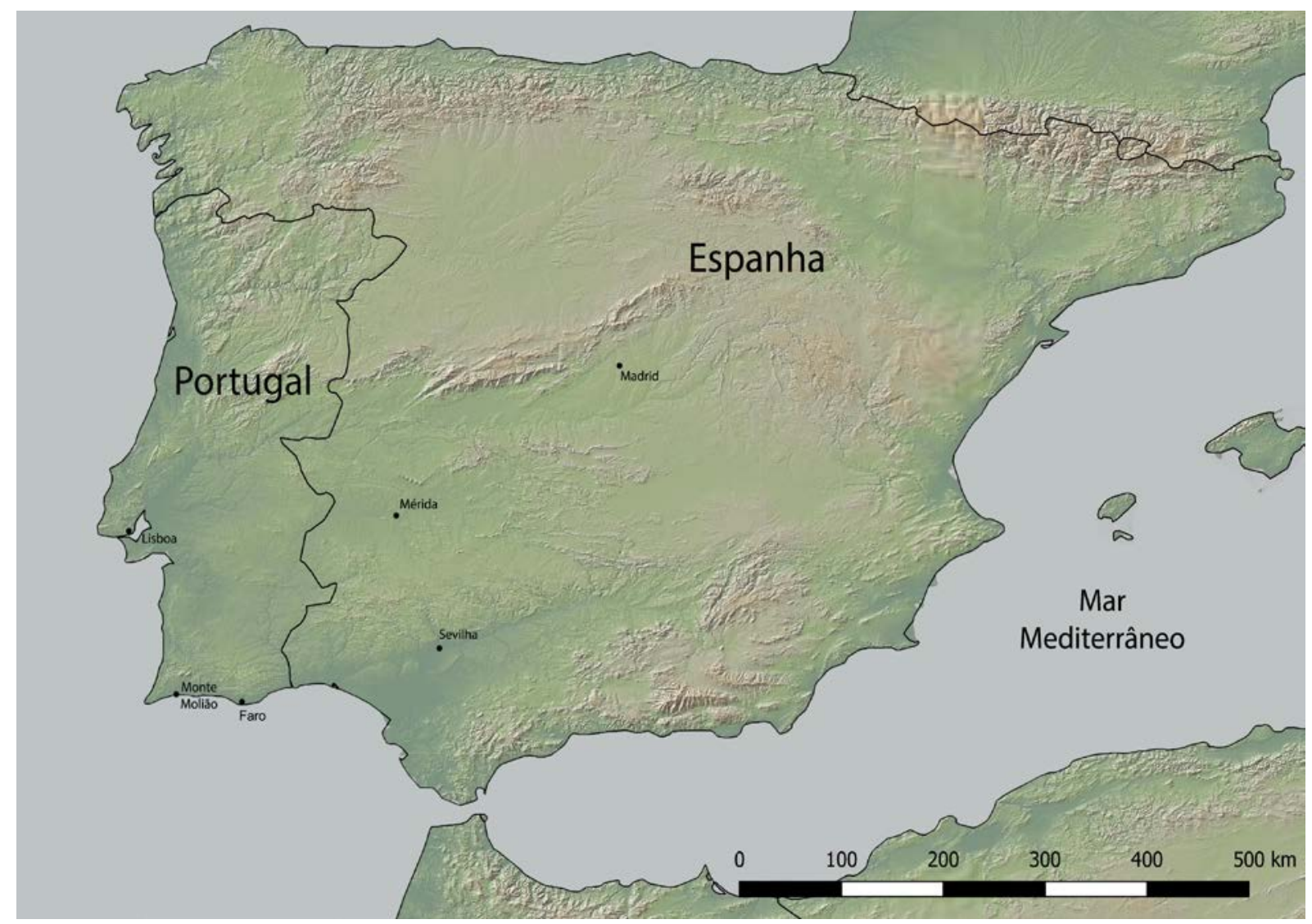

Figura 1. Localização de Monte Molião (Lagos, Portugal). Mapa de base: Global Multi-Resolution Topography (GMRT), Version 3.4. (adaptado).

\section{INTRODUÇÃO}

A cisterna implantada sensivelmente no topo de Monte Molião era, até há pouco tempo, a mais bem conservada e conhecida estrutura arqueológica do sítio localizado na margem esquerda da Ribeira de Bensafrim (figs. 1 e 2). Ainda que se trate de um monumento escavado na rocha, não se projectando, portanto, em altura, a verdade é que o seu impacto é grande, sobretudo pela visibilidade que, apesar de tudo, adquire, pelas suas dimensões e estado de conservação. Por outro lado, foi, até ao início dos trabalhos arqueológicos levados a efeito na última década, a única construção antiga visível, situação que decorria do facto de, no século XIX, ter sido parcialmente esvaziada.

A estrutura destinada ao armazenamento de água foi descrita com precisão por Estácio da Veiga, que refere expressamente que assistiu à sua "escavação", realizada a mando do proprietário do terreno, o Sr. João Pimenta, por trabalhadores da propriedade, tendo deixado registado que «...a construção mais regular que observei foi uma cisterna elliptica, com $4^{m}, 35$ de profundidade, $1^{m}, 76$ de largura e $6^{m}, 80$ de comprimento» (Veiga 1910: 222). Esta "escavação" antiga concretizou-se na área SE, tendo implicado não só a evacuação de todos os sedimentos neste sector, mas também o desmonte da totalidade dos componentes construtivos e mesmo a destruição parcial do fundo da estrutura. A cavidade, com mais de $4 \mathrm{~m}$ de profundidade, que ficou aberta, foi sendo utilizada como área de despejos de lixos e de restos diversos ao longo do século passado, despejos que iam sendo tapados com terras ou pedras de média dimensão. Esta utilização ficou bem demonstrada durante a escavação de 2011, quando se recuperaram esqueletos completos de animais domésticos, concretamente de cães e de gatos, nas camadas de terra que entulharam, em momentos diversos, a fossa que resultou da "escavação" da área Sul da cisterna de Monte Molião no final do século XIX.

No âmbito do protocolo que une a Câmara Municipal de Lagos e a Faculdade de Letras de Lisboa em torno 


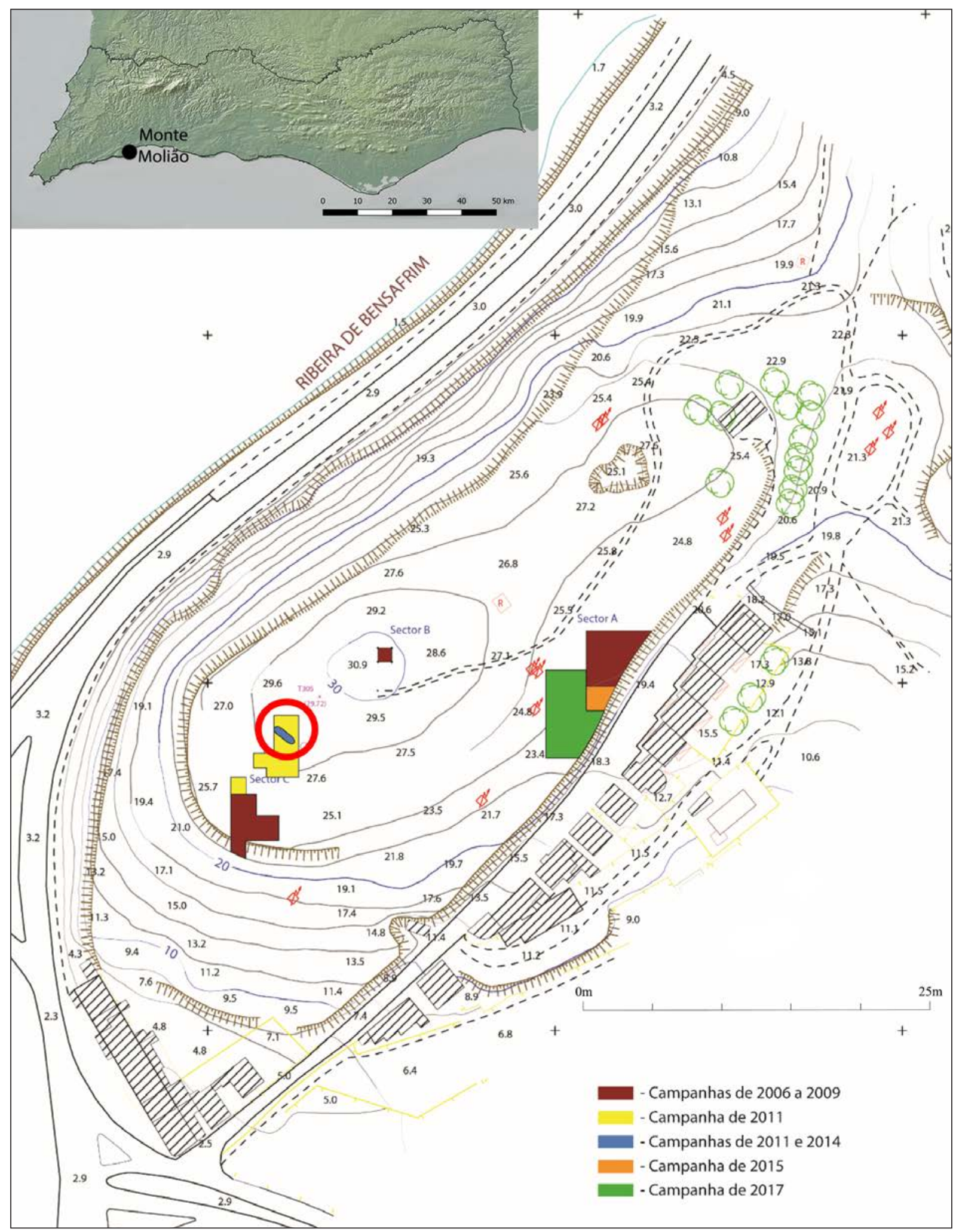

Figura 2. Planta topográfica do sítio com localização dos respectivos sectores e alargamentos efectuados nas várias campanhas. O círculo assinala a localização da cisterna. 


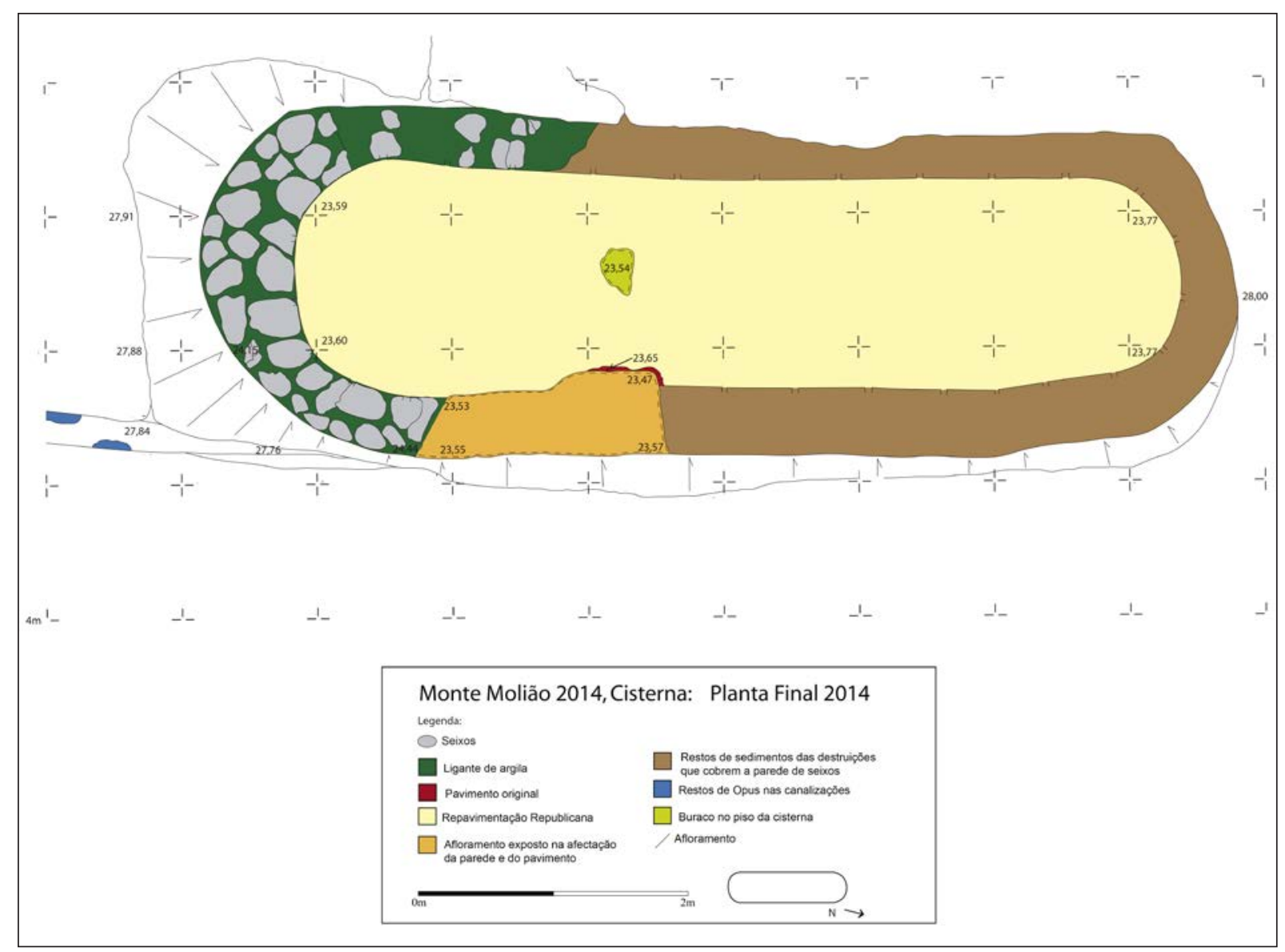

Figura 3. Planta da cisterna de Monte Molião.

deste importante sítio arqueológico do Sul de Portugal, e que se tem consubstanciado em trabalhos de campo e de gabinete, bem como na publicação dos dados neles obtidos, a cisterna foi, em 2011 e 2014, alvo de escavação arqueológica e de intervenção de conservação e restauro. Os resultados alcançados com estes trabalhos trouxeram importantes dados sobre técnicas construtivas usadas em época antiga, pelo menos para a edificação de estruturas hidráulicas, tendo possibilitado também obter informação sobre um momento ainda relativamente mal caracterizado da ocupação do sítio, a dinastia júlio-cláudia, ainda que apenas no que se refere à cultura material.

\section{CARACTERIZAÇÃO ARQUITECTÓNICA E CONSTRUTIVA}

As vicissitudes da história da cisterna do Monte Molião, reflectidas no registo arqueológico que pôde documentar-se nas campanhas de escavação de 2011 e 2014 (fig. 3), geraram umas condições particularmente interessantes para o estudo das técnicas construtivas empregues na realização deste tipo de estruturas hidráulicas.

Com efeito, esta cisterna apresentava uma zona em muito bom estado de conservação que permitiu compreender até certo ponto a configuração original da mesma e os acabamentos que a adaptavam à sua funcionalidade (fig. 4).

Por outro lado, contudo, possuía uma zona profundamente alterada por violações que podem datar-se, como já ficou dito, do final do século XIX (fig. 5). No entanto, e sem querer minimizar o impacto negativo destas acções na conservação da cisterna e dos depósitos contidos no seu interior, a verdade é que a profunda afectação da estrutura na sua extremidade meridional permitiu observar certos aspectos relacionados com a construção e com eventuais reparações estruturais que de outra forma não teria sido possível documentar. 


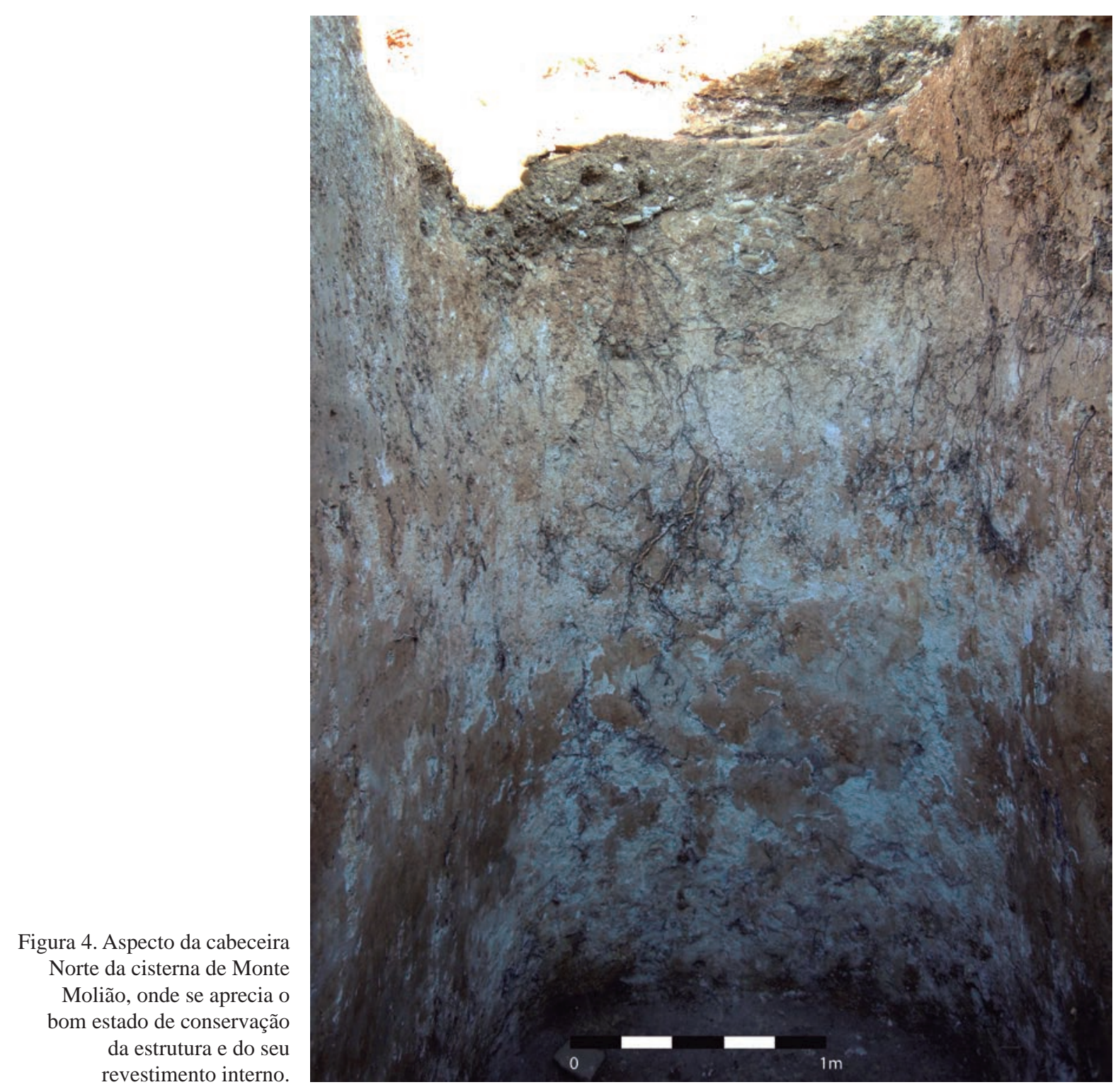

Assim, e em face dos dados recolhidos na escavação, pode precisar-se que o alvéolo desta cisterna, escavado nas bancadas de calcário que compõem o substrato geológico local, foi revestido por uma estrutura de alvenaria composta por seixos rolados de quartzito unidos por um ligante argiloso de natureza fortemente plástica, de coloração esverdeada (figs. 6 e 7). Esta alvenaria apresenta uma espessura algo irregular, entre os 0,31 e os $0,69 \mathrm{~cm}$, possivelmente como resultado da necessidade de regularizar o alvéolo subjacente.

A superfície desta alvenaria foi, por sua vez, revestida e regularizada recorrendo a uma técnica em três passos: em primeiro lugar, a superfície da alvenaria foi normalizada mediante a aplicação de uma argamassa de cal e areia de grão mais grosseiro (c 2,2 a 3,5cm); sobre esta, aplicou-se uma camada de cal e areia fina ( $c$ $0,8 \mathrm{~cm}$ ), possivelmente com adição de cinzas, servindo de reboco; finalmente, a superfície foi cuidadosamente acabada com uma capa de cal fina $(c 0,3 \mathrm{~cm})$, bem alisada (figs. 6 e 8).

Em relação à base da cisterna, a documentação das técnicas construtivas empregues só foi possível graças à existência no seu sector Sudeste de uma zona onde o desmonte da estrutura de alvenaria aquando das violações antes comentadas se prolongou em profundidade, afectando também o revestimento da base (fig. 5). 


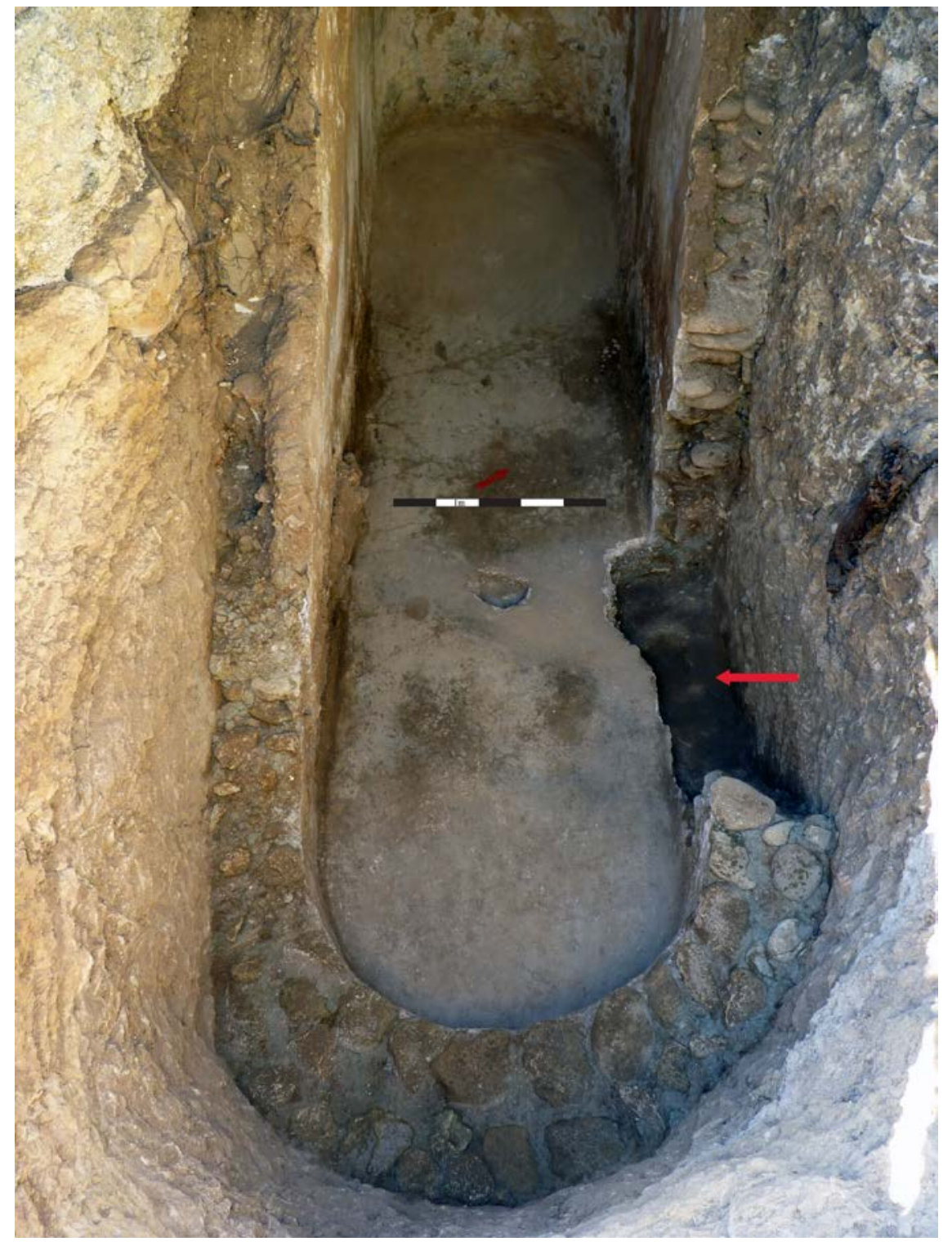

Figura 5. Aspecto da cisterna após a escavação; a seta assinala a área de aprofundamento da fossa de violação do século XIX na interface da qual foi possível documentar a técnica construtiva do fundo da cisterna e o episódio de repavimentação de Época Romana Republicana.
Assim, a observação do corte produzido pela interface da referida violação permitiu apreciar que o fundo do alvéolo escavado na rocha terá sido revestido com recurso a um aparelho de alvenaria de seixos e argila esverdeada, em tudo similar ao das paredes laterais, a que se seguia uma espessa $(10 \mathrm{~cm})$ camada de opus caementicium, capeada por uma argamassa de cal e areia de grão grosseiro, que, na zona de contacto com as paredes laterais, se aplicou de forma a gerar um ângulo arredondado, em meia-cana suave. Esta característica, típica das estruturas hidráulicas, elimina a existência de ângulos nos quais se poderiam acumular impurezas passíveis de contaminar a água depositada (Bonetto et al. 2012: 2606) e permite reforçar a área de contacto entre a parede e o fundo do depósito, por natureza estruturalmente frágil.

A existência do referido corte permitiu ainda constatar um episódio de reparação ou de repavimentação, que consistiu na aplicação de uma camada relativamente fina (c de $2 / 3 \mathrm{~cm}$ ) de opus signinum (fig. 9). Esta situação foi perfeitamente constatada do ponto de vista estratigráfico, como se pode observar pelas imagens da figura 9 e não ofereceu quaisquer dúvidas.

Embora imprecisa, a cronologia desta reparação parece poder enquadrar-se no período Romano Republicano devido à presença de uma quantidade apreciável de fragmentos cerâmicos de proveniência itálica (cf. infra). 
Figura 6. Estrutura de alvenaria e revestimento da cisterna visto em corte na interface da violação do século XIX.

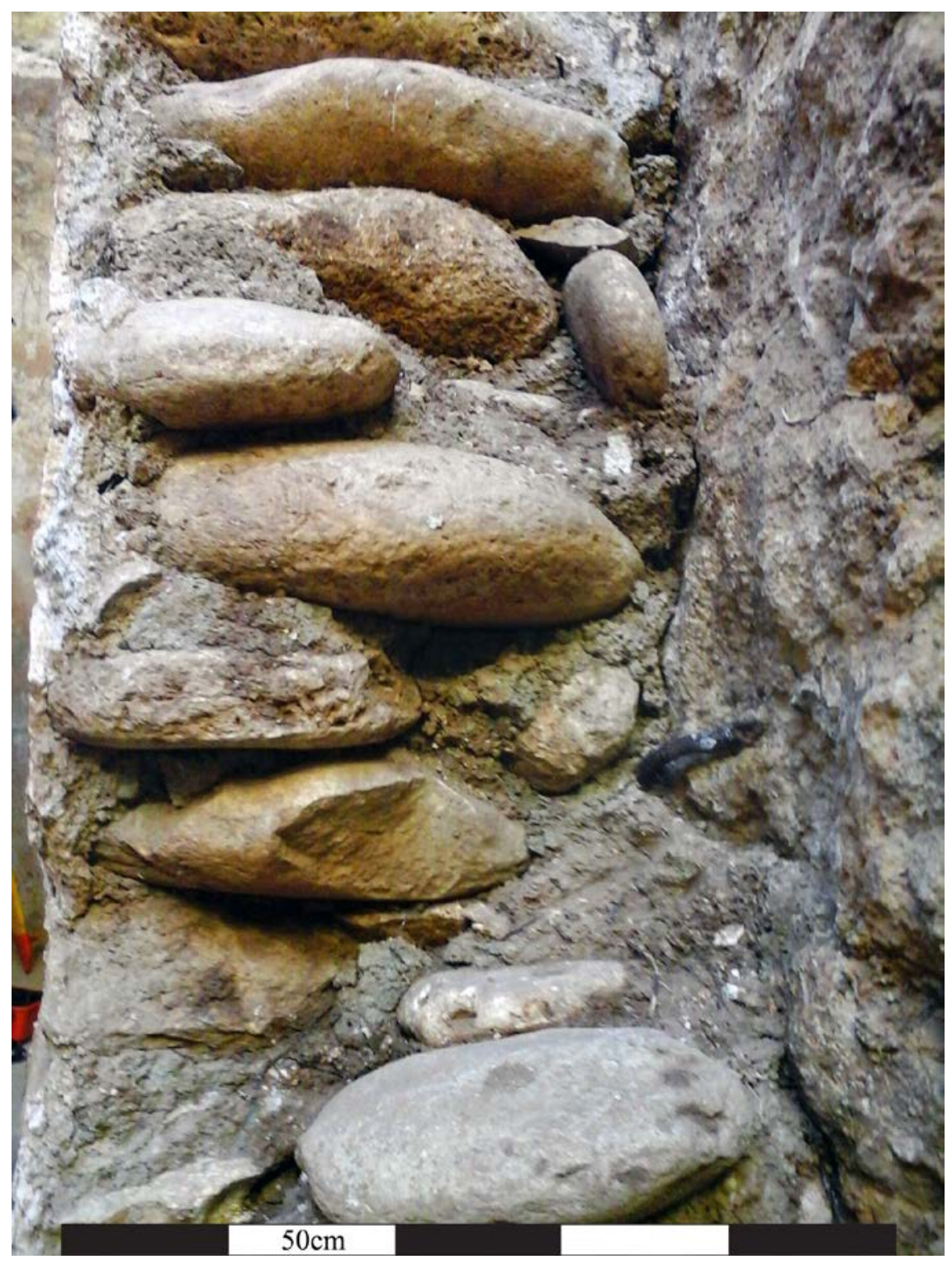

Na porção central do pavimento da cisterna verificou-se a existência de uma pequena depressão de morfologia irregular, com cerca de $10 \mathrm{~cm}$ de profundidade, que a priori caberia interpretar como um elemento destinado a facilitar a limpeza do depósito de água.

A estrutura resultante, com uma orientação, aproximadamente, Norte - Sul, apresenta uma configuração estreita e alongada, com extremidades semicirculares bastante regulares, o que, como adiante se comentará, permite a sua integração no grupo bem tipificado das cisternas ditas a bagnarola (fig. 10).

Tal como hoje se conserva, este depósito apresenta um comprimento máximo na ordem dos 6,56m e uma largura máxima em torno aos $1,55 \mathrm{~m}$; a sua profundidade máxima restituível alcança os 4,34m. O cálculo da volumetria desta estrutura permite afirmar que a mesma teria uma capacidade aproximada de $42,34 \mathrm{~m}^{3}$, o que equivale a cerca de $42.340 \mathrm{l}$.

Não pode, no entanto, excluir-se que a volumetria original desta cisterna fosse algo superior. A zona envolvente encontra-se, com efeito, muito exposta aos efeitos da erosão, sendo hoje facilmente observável o avançado estado de desagregação das bancadas calcárias superficiais, nomeadamente no lado ocidental da estrutura. Não é por isso impossível que a cisterna fosse originalmente um pouco mais profunda. 


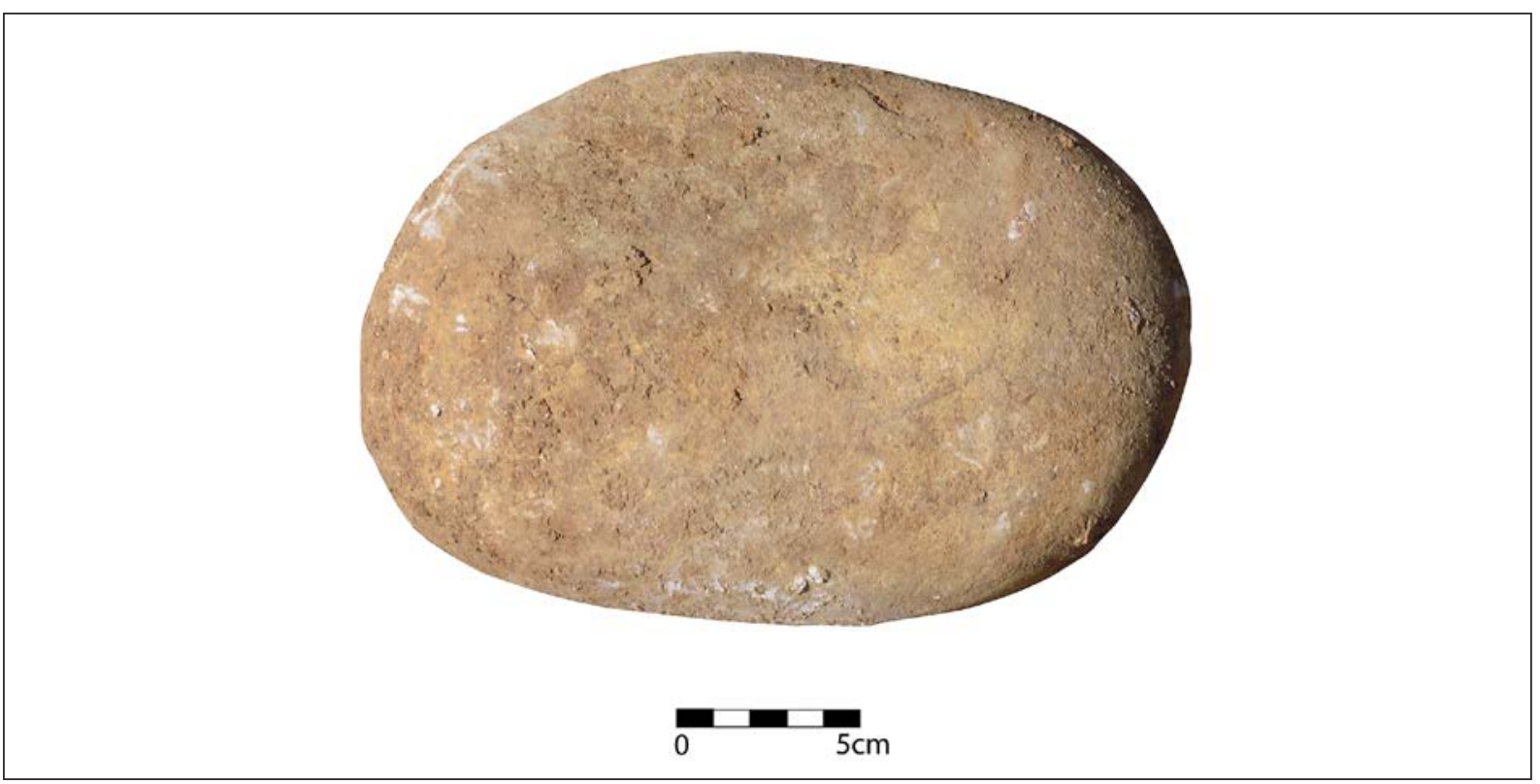

Figura 7. Exemplo do tipo de seixo utilizado na construção da alvenaria da cisterna.

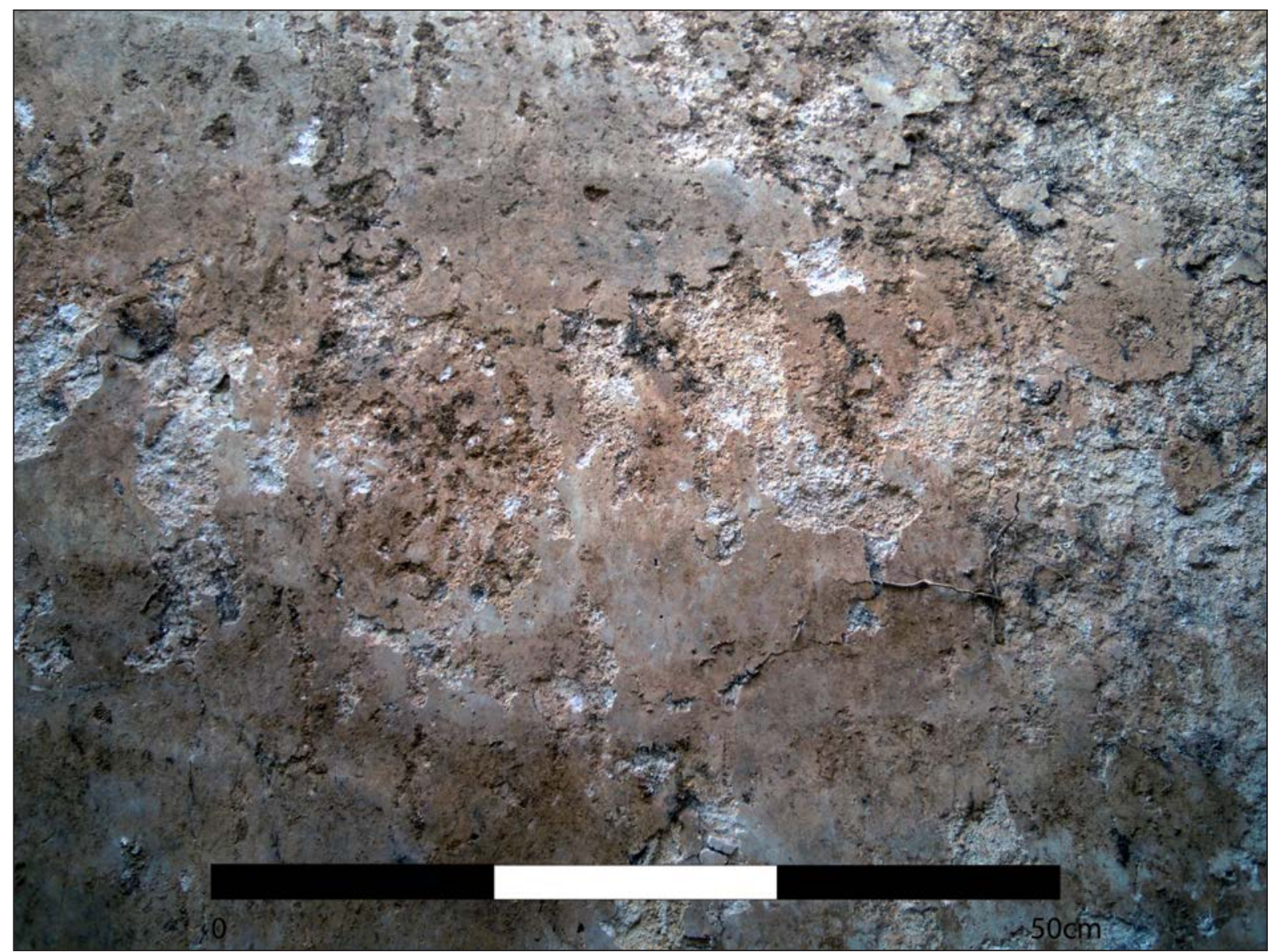

Figura 8. Aspecto da superfície do revestimento interno da cisterna na zona mais bem conservada da cabeceira Norte. 


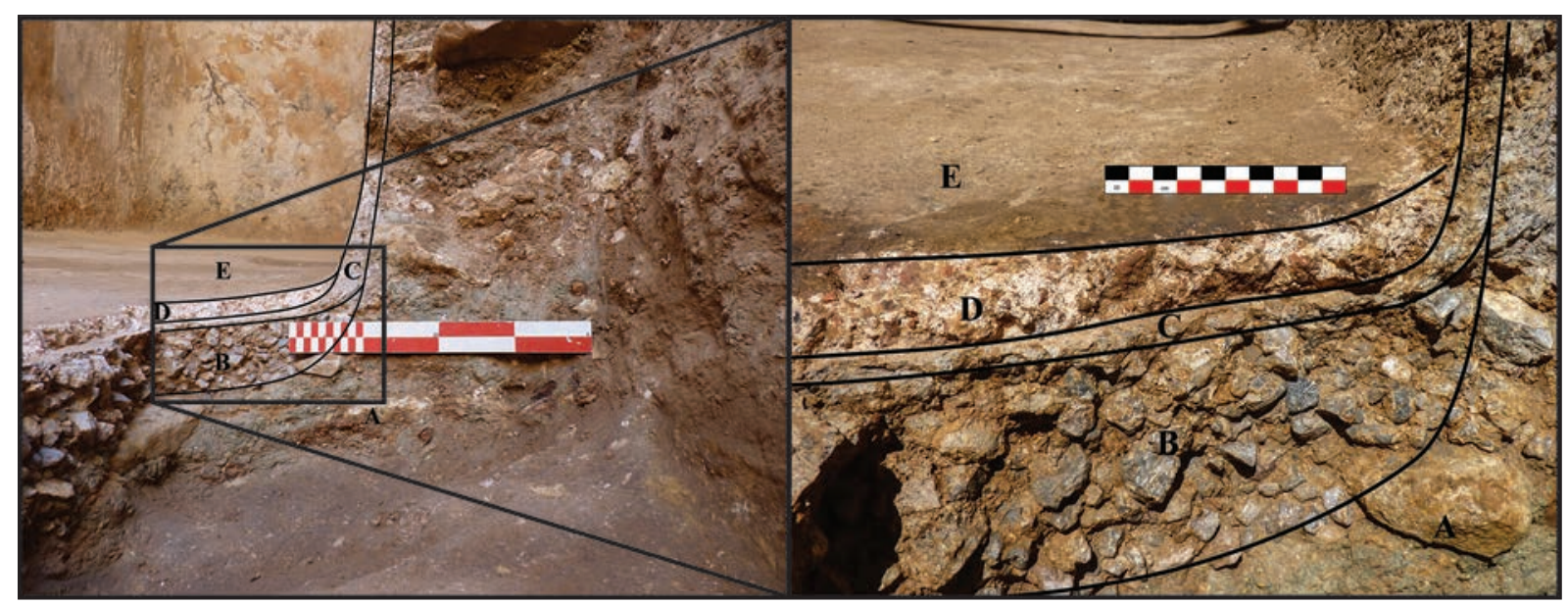

Figura 9. Aspecto do estrato de repavimentação de Época Romana Republicana e estratigrafia de construção. A - Aparelho de alvenaria de seixos e argila; B - Camada de opus caementicium; C - Argamassa de cal e areia; D - Repavimentação de opus signinum; E - Revestimento da base da cisterna.

Infelizmente, não dispomos de dados relevantes para a discussão do sistema de cobertura desta cisterna, do qual não se conservam quaisquer vestígios. Assim, e no sentido de tentar restituir esse sistema, podemos unicamente evocar algumas situações documentadas em cisternas tipologicamente comparáveis à do Monte Molião.

Deste modo, pode recordar-se que as cisternas $a$ bagnarola, tipicamente muito estreitas, contam com frequência com coberturas muito simples, constituídas por grandes lajes aplicadas horizontalmente sobre a estrutura ou, em alguns casos, por lajes colocadas obliquamente e apoiadas entre si formando coberturas de duas águas (Wilson 2001: 67; Baklouti 2010: 185; Bonetto et al. 2012: 2607; Lara Medina 2018: 151). A ausência de dados seguros não nos permite asseverar qual destas soluções terá sido empregue no sítio algarvio.

Finalmente, e do ponto de vista das soluções de alimentação da cisterna, deve assinalar-se uma vez mais que os efeitos da erosão em toda esta zona superior do Monte Molião condicionam sobremaneira as leituras possíveis.

Ainda assim, foi possível reconhecer à superfície a existência de um pequeno canal de secção semicircular escavado na rocha que desaguaria no ângulo Sudeste da cisterna (fig. 11, A). No interior deste conservam-se ainda restos de opus signinum que, somados à pendente que apresenta, sugerem que o mesmo terá servido para canalizar as águas pluviais para o interior da cisterna, funcionando como adutor; não pode, contudo, precisar-se o tipo de estrutura de captação do qual partiria. A utilização do opus signinum nesta estrutura poderia levar a pensar que a mesma corresponde a um acrescento contemporâneo ao episódio de repavimentação antes comentado.

Mais difícil de interpretar é um conjunto de estruturas rectangulares com esquinas arredondadas escavadas na rocha no rebordo oriental da cisterna. As mesmas não continham quaisquer depósitos arqueológicos no seu interior, o que dificulta o seu enquadramento cronológico e, por extensão, a interpretação da sua relação com a construção em análise.

A primeira destas estruturas, implantada de forma perpendicular à cisterna e conectada com esta no seu terço Norte, apresenta uma configuração rectangular alongada, hoje muito alterada, com um comprimento máximo da ordem dos $37,5 \mathrm{~cm}$ e uma largura máxima de $10,5 \mathrm{~cm}$. A sua profundidade é de aproximadamente $13 \mathrm{~cm}$. Esta fossa comunica na sua esquina Nordeste com um aparente canal de forma irregular, não documentado em extensão (fig. 11, B).

Uma segunda estrutura, igualmente rectangular, apresenta uma implantação ligeiramente oblíqua com respeito ao eixo da cisterna, comunicando com a mesma na sua porção intermédia. Apresenta um comprimento máximo de $27,5 \mathrm{~cm}$, uma largura de $33 \mathrm{~cm}$ e uma profundidade máxima de $11 \mathrm{~cm}$ (fig. 11, C). Esta estrutura não se apresenta conectada a nenhum outro elemento reconhecível.

Finalmente, uma terceira estrutura de aspecto mais complexo comunica com a cisterna no seu terço meridional. Esta fossa apresenta um primeiro patamar de configuração grosso modo quadrangular, com um comprimento máximo de $50 \mathrm{~cm}$ para uma largura máxima de $45 \mathrm{~cm}$ e uma profundidade entre os 11 e os $15 \mathrm{~cm}$ 
(fig. 11, D). Esta depressão, perfeitamente perpendicular com relação ao eixo da cisterna, comunica no seu ângulo sudoeste com um canal que apresenta uma orientação similar ao anteriormente comentado.

No interior deste primeiro patamar, na zona que comunica com a cisterna, escavou-se uma segunda estrutura de contornos rectangulares, ligeiramente descentrada com respeito à anterior, com $30 \mathrm{~cm}$ de comprimento por $19 \mathrm{~cm}$ de largura, e uma profundidade de $5 \mathrm{~cm}$ em relação ao primeiro patamar antes descrito.

Como ficou dito acima, o facto de estas estruturas negativas se encontrarem à superfície, não contando com depósitos primários associados, e de toda a zona ter sofrido uma intensa erosão, que se adivinha ter afectado substancialmente a supraestrutura da própria cisterna, tornam sumamente difícil interpretar a sua relação com o depósito propriamente dito. Porém, se as interpretarmos, total ou parcialmente, como parte integrante do projecto arquitectónico da cisterna - o que parece lícito - poderia eventualmente pensar-se que correspondem a algum tipo de tanques de decantação, destinados à purificação das águas conduzidas pelos canais antes comentados, embora seja difícil restituir de forma exacta o funcionamento dos mesmos. No entanto, e como ficou dito, os dados para interpretar funcionalmente estas realidades são manifestamente insuficientes.

Por outro lado, a Oeste deste grupo construtivo documentou-se, igualmente à superfície, um conjunto de estruturas escavadas na rocha de função (e cronologia) duvidosa, nomeadamente uma pequena fossa de planta subcircular com um diâmetro de cerca de 9,5cm e uma profundidade de $12 \mathrm{~cm}$ e um aglomerado de estruturas negativas, incluindo uma fossa circular de maiores dimensões $(21,5 \mathrm{~cm}$ de diâmetro, $25 \mathrm{~cm}$ de profundidade) com um entalhe sub-rectangular escavado no seu rebordo meridional, uma segunda fossa circular, mais pequena $(8,5 \mathrm{~cm}$ de diâmetro, $10 \mathrm{~cm}$ de profundidade) e uma fossa rectangular com as esquinas arredondadas, de orientação Noroeste-Sudeste (18cm de comprimento, $9 \mathrm{~cm}$ de largura e $26 \mathrm{~cm}$ de profundidade) (fig. 11, E).

Ainda no que diz respeito à possível existência de construções auxiliares relacionadas com este depósito pode assinalar-se que nos estratos de amortização da cisterna se recolheu uma grande quantidade de argamassas ricas em fragmentos cerâmicos (especialmente de ânforas itálicas) (cf. infra), que poderiam, como mera hipótese, relacionar-se com o programa de remodelação antes comentado. Muitos destes fragmentos apresentam superfícies aplanadas, podendo pensar-se que integrariam pavimentos implantados sobre a cobertura da cisterna (cf., p. ex., Baklouti 2010: 204) ou em alguma estrutura da sua envolvente, embora não exista qualquer evidência directa que permita confirmar esta hipótese.

O conhecimento da volumetria aproximada deste depósito de água permite ainda tecer algumas considerações adicionais sobre o tema dessas eventuais estruturas auxiliares. Com efeito, se tomarmos como base, por um lado, a capacidade da cisterna (42.340 1) e, por outro, e a título meramente indicativo, o valor da precipitação média anual da região algarvia nos últimos 50 anos $(497,11 \mathrm{~mm}$ - valor calculado a partir dos níveis registados pela estação meteorológica de Faro, disponíveis no portal Pordata, https://www.pordata.pt/Portugal/Precipita\%C3\%A7\%C3\%A3o+total-1070-10195, consultado a 29/05/2018), pode facilmente calcular-se que a área de captação necessária para a alimentação desta cisterna deverá ter sido considerável. Com efeito, e em face destes valores de referência, para alcançar um único enchimento anual completo seria necessária em média uma área de captação de cerca de $85 \mathrm{~m}^{2}$, muito superior, portanto, aos $9,71 \mathrm{~m}^{2}$ de área do depósito da cisterna propriamente dito, isto sem tomar em consideração as expectáveis perdas por evaporação.

Assim, e mesmo contando com a água canalizada através de canais, cujo contributo para o abastecimento da cisterna poderá não ter sido desdenhável, não é descabido pensar que esta estrutura terá contado com uma área de impluvium relativamente ampla na sua envolvente.

A concluir esta discussão das estruturas envolventes da cisterna, caberia ainda referenciar, mesmo que brevemente, a existência na vertente ocidental da mesma, a cerca de 4m da sua esquina Sudoeste, de uma outra estrutura escavada na rocha, correspondente a uma fossa com uma planta subcircular algo irregular ao nível da abertura, mas com um fundo de secção quadrangular de 40 por $40 \mathrm{~cm}$ (fig. 11, F). Os depósitos contidos no interior desta estrutura, também ela muito superficial, revelaram-se arqueologicamente estéreis, pelo que a interpretação cronológica e funcional da mesma constitui um problema de difícil resolução. A relação desta estrutura com a cisterna não pode considerar-se minimamente demonstrada, embora devido à sua proximidade e à ausência de outros vestígios construtivos nesta área nos pareça interessante incluir uma menção à mesma no contexto deste estudo.

\section{TIPOLOGIA, PARALELOS E ENQUADRAMENTO CULTURAL}

Como se adiantou nas páginas precedentes, a cisterna do Monte Molião integra-se pela sua morfologia, mas também pelas suas técnicas construtivas, numa tipologia 


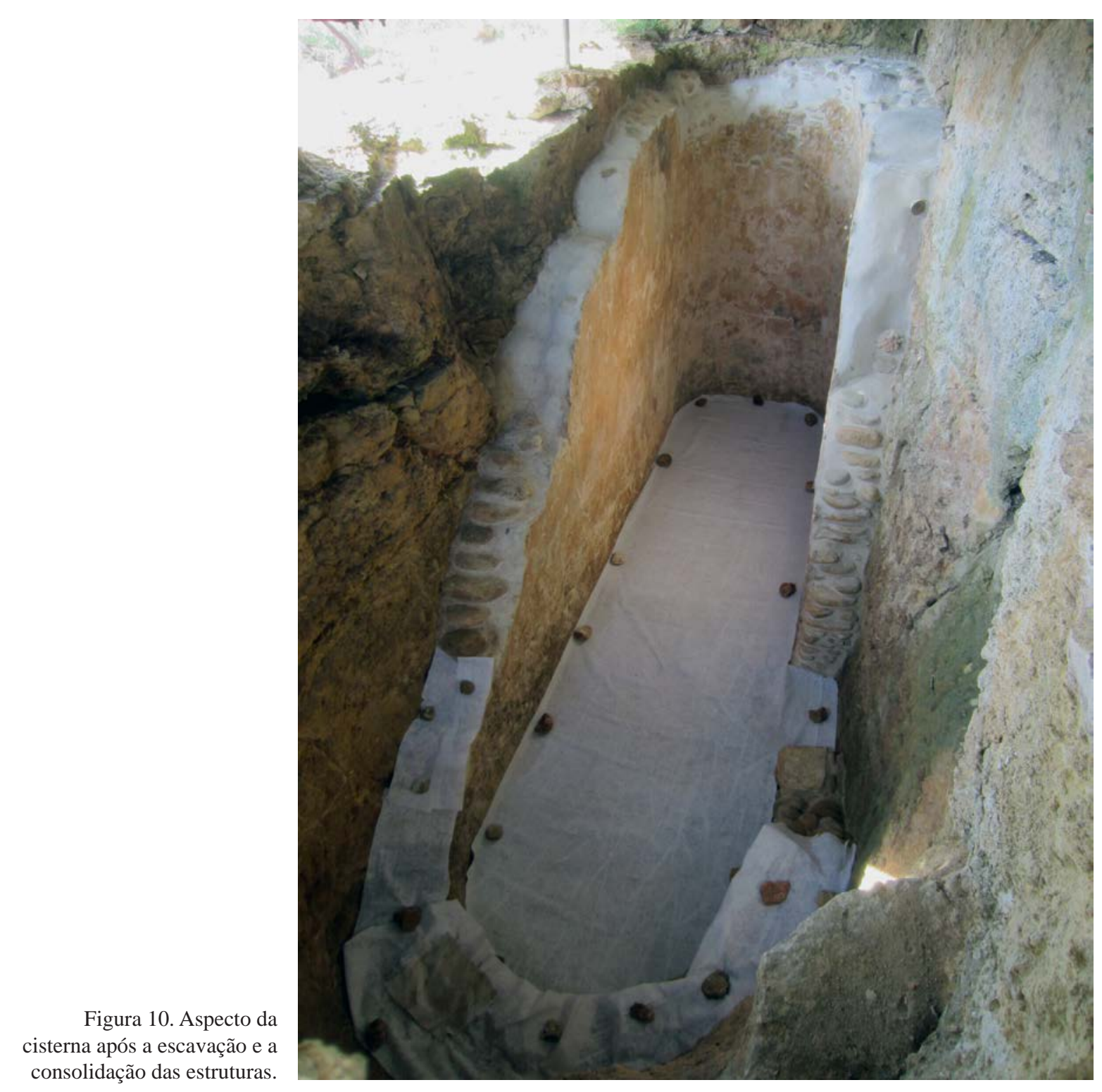

bem conhecida, correspondendo de forma muito clara ao tipo das cisternas ditas a bagnarola, ocasionalmente também designadas elípticas (cf., p. ex., Burés Vilaseca 1998: 60-62; Mezzolani 2010: 1763-4).

Os protótipos deste tipo de cisternas, muito bem representado em diversas áreas do Mediterrâneo Central e Ocidental, devem buscar-se no âmbito cultural púnico (Fantar 1975; Ruiz Acevedo e Delgado Béjar 1991: 19-20; Burés Vilaseca 1998: 60 -62; Wilson 2001: 67; Baklouti 2010: 185-189; Mezzolani 2010: 1763-4). Com efeito, as cisternas do tipo em apreço documentam-se no Mediterrâneo Central a partir do século IV a.n.e., conhecendo, contudo, a sua maior difusão a partir da centúria seguinte.
Em Cartago, em particular, as escavações realizadas durante as últimas décadas do século XX por várias equipas permitiram documentar uma profunda transformação do regime de aprovisionamento de água ocorrida justamente durante o século III a.n.e. e a primeira metade do século II a.n.e. Neste momento o sistema hídrico anterior, caracterizado pelo uso de poços, é amplamente abandonado, quiçá como consequência da contaminação progressiva dos níveis freáticos (Wilson 2001: 65-67), sendo substituído por outro baseado em cisternas, cuja implementação comportou importantes alterações às estruturas domésticas envolventes (ibidem). 
Esta tipologia de cisterna encontra-se também bem atestada neste mesmo período no hinterland púnico de Cartago - destacando-se o caso da fortaleza e do templo de Ras ed-Drak, no Cabo Bon (Barreca e Fantar 1983), cujo estudo foi fundamental no seu momento para estabelecer a datação pré-romana das cisternas $a$ bagnarola, ou o de Útica (Lézine 1968: 101) -, bem como no âmbito númida, com exemplos representativos em Dougga e em Kalaat Bezzaz (Baklouti 2010).

As cisternas deste grupo estão também bem representadas nas áreas do Mediterrâneo Central sob a influência directa de Cartago, nomeadamente na Sardenha, onde ocorrem nos centros púnicos de Nora (Bonetto et al. 2012; Cespa 2013-2014), Cagliari (Cespa 2013-2014: 22-36), Sant'Antioco (idem: 52), Tharros (Bultruni et al. 1996) e Olbia (Mezzolani 2010), na Sicília, com pelo menos um exemplo atestado em Mozia (Brancoli et al. 1967), e na ilha de Pantellería (Castellani e Mantellini 2001).

Esta situação reproduz-se no Mediterrâneo Ocidental e na Península Ibérica (fig. 12), onde as cisternas $a$ bagnarola ocorrem com certa frequência em sítios púnicos ou de tradição púnica, nomeadamente em Ibiza (Ramon Torres 1985; Costa Ribas 2007), Tossal de Manises (Alicante) (Olcina Doménech et al. 2010), Cartagena (Egea Vivancos 2003; Ramallo Asensio e Martín Camino 2015), Villaricos (Almería) (López Castro 2005), Carmona (Sevilha) (Conlin Hayes 2001: 207), Cádis (Lara Medina 2018), Carteia (Ruiz Acevedo e Delgado Béjar 1991: 20; Roldán 1992: fig. 70) ou Cerro Naranja (Mata Almonte 2009: 110-112), na província de Cádis.

No entanto, no contexto da Península Ibérica, caberia também referenciar a presença de cisternas $a$ bagnarola em ambiente grego helenístico, e mais especificamente os abundantíssimos exemplos documentados na Neápolis da colónia grega de Emporion (Ampúrias) (Burés Vilaseca 1998), a partir de onde esta tipologia parece ter irradiado para o hinterland indígena do Nordeste peninsular, documentando-se em Ullastret e em Castells (Gerona) (idem: 62; de Prado 2008), mas também mais a Sul, em El Castellar de Meca (Valência) (Egea Vivancos 2010: 128) e talvez em Sagunto (Valência) (Civera i Gómez 2007).

Também na Andaluzia são abundantes os exemplos de cisternas deste tipo em sítios indígenas ou com raízes indígenas (Ruiz Acevedo e Delgado Béjar 1991: 17-21; Mata Almonte 2009; Castro García 2017), podendo destacar-se a cisterna do povoado ibérico do Cerro de la Cruz de Almedinilla (Córdoba) (Vaquerizo Gil 1990) por se tratar de um dos exemplos mais seguros da difusão deste tipo de cisternas em ambientes indígenas peninsulares ainda em época pré-romana (cf. infra). Outros exemplos incluem as cisternas de Granada (Lozano Rodríguez et al. 2008), de Cástulo (Blázquez et al. 1984), de Cerro de la Horca (Ruiz et al. 1990), de Monturque (Castro García 2016: 606 e ss.) e de Cabeza del Obispo (Jiménez Higueras 2005: 14 e Lám. 2), todas na província de Jaén, de Ategua (Fortes Santos et al. 2011) e de Torreparedones (Morena López 2016), ambas em Córdova, de Lacipo (Málaga) (Puertas Tricas 1982), de Ocuri (Cádis) (Guerrero Misa 2009), de Zahara de la Sierra, também em Cádis (Cobos Rodríguez e Iglesias García 2011) e de Cerro Salomón, em Huelva (Pérez Macías 2018: 79-80).

A ampla difusão deste tipo de cisterna, que transcende largamente o âmbito púnico no qual parece originar-se, dever-se-á não somente à influência cultural desse âmbito - que sem dúvida desempenhou um papel fulcral em muitos contextos - mas também às próprias virtualidades desta solução construtiva.

Com efeito, e além de comparativamente fáceis de construir, as cisternas a bagnarola apresentam características técnicas particularmente ajustadas à sua função. As extremidades semicirculares, em particular, não só eliminam a existência de arestas de difícil limpeza - e, portanto, possíveis focos de contaminação - como actuam na prática como arcos de descarga, distribuindo a pressão do terreno envolvente sobre os seus lados menores, mais frágeis, para os seus lados longos mais resilientes (Ruiz Acevedo e Delgado Béjar 1991: 20).

A elevada adequação funcional deste tipo de cisterna poderá contribuir para explicar o seu uso preferencial mesmo em âmbitos onde se conhecem e empregam outras tipologias, como no caso da Ampúrias helenística (Burés Vilaseca 1998).

No presente contexto, e para lá da distribuição geográfica do tipo em discussão, importa também reter os dados disponíveis sobre o enquadramento cronológico destas estruturas a bagnarola. Estes, contudo, nem sempre são particularmente expressivos. Com efeito, ao corresponder a estruturas escavadas na rocha, a datação da construção destas cisternas é frequentemente difícil, ou mesmo impossível.

Por outro lado, e por razões óbvias, estes depósitos seriam limpos com relativa frequência, pelo que os estratos e materiais recuperados no seu interior dão conta unicamente da sua fase de abandono e/ou amortização, sendo este o único dado cronológico para muitas das cisternas documentadas nos sítios antes mencionados. Posto que muitas destas estruturas conheceram períodos muito longos de uso, denunciados, por exemplo, 
Figura 11. Planta da área envolvente da cisterna onde se apreciam diversas estruturas escavadas na rocha de funcionalidade incerta, mas plausivelmente relacionadas com 0 abastecimento de água: A - canalização revestida a opus signinum; B a D recortes rectangulares; $\mathrm{E}$ - conjunto de estruturas negativas de planta circular; F - depressão de configuração quadrangular.

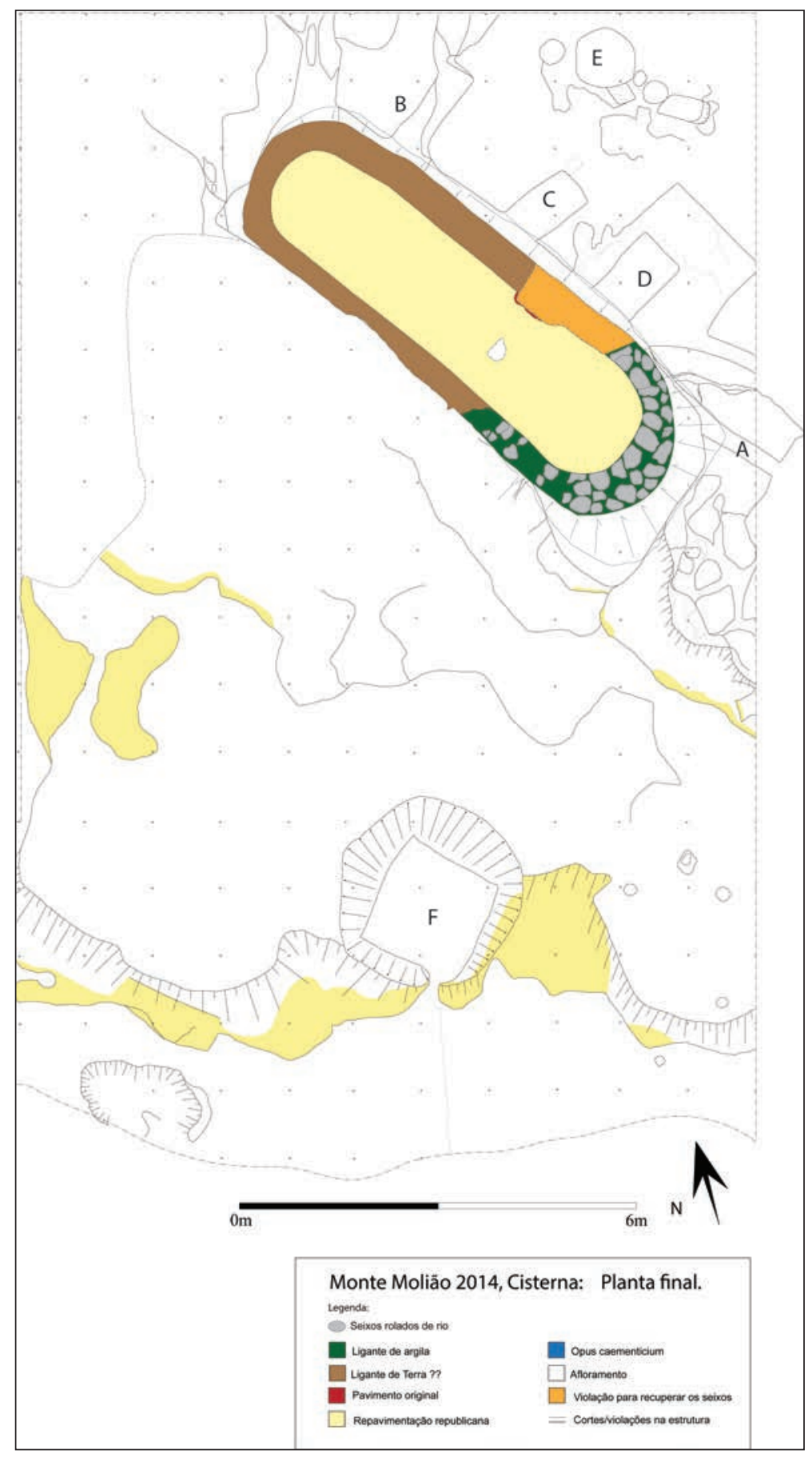

por reparações e acrescentos, este dado reveste-se naturalmente de um carácter problemático.

No entanto, recorrendo a alguns casos que oferecem dados cronológicos mais fiáveis, é possível esboçar uma aproximação geral à distribuição cronológica deste modelo arquitectónico. Assim, pode afirmar-se que as mais antigas cisternas a bagnarola se documentam no Mediterrâneo Central, em Cartago, em Sant'Antioco e possivelmente em Cagliari e em Olbia, na Sardenha, onde a tipologia aparece já durante o século IV a.n.e. (Wilson 2001; Mezzolani 2010: 1768; Cespa 2013-2014). 
Contudo, e como ficou dito anteriormente, a generalização destas cisternas em Cartago só se iniciou no século III a.n.e. (Wilson 2001), sendo também este o momento em que o seu uso se difundiu no hinterland norte-africano daquela metrópole (Barreca e Fantar 1983; Baklouti 2010). Em outras áreas do Mediterrâneo Central - e com as possíveis excepções sardas, já referidas, e talvez a de Mozia (Brancoli et al. 1967) - as estruturas deste tipo para as quais se dispõe de dados, nomeadamente as de Nora (Cespa 2013-2014), parecem construir-se já em época romana republicana (v. tb. Mezzolani 2010)

Na Península Ibérica, pelo contrário, a introdução das cisternas a bagnarola ainda no século III a.n.e. está bem atestada em Ampúrias (Burés Vilaseca 1998), em Sagunto (Civera i Gómez 2007), no Tossal de Manises (Olcina Doménech et al. 2010), no Cerro de la Cruz de Almedinilla (Vaquerizo Gil 1990; Quesada et al. 2010: 95) e no Cerro Naranja (Mata Almonte 2009: 110-112), enquanto que um depósito de água deste tipo de Cartagena foi recentemente atribuído, de forma tentativa, ao período bárquida da cidade (Ramallo Asensio e Martín Camino 2015: 132-133).

Contudo, não faltam também exemplos que poderão ter-se construído já após a conquista romana, em particular em Cádis (Lara Medina 2018), em Granada (Lozano Rodríguez et al., 2008) e em Ampúrias (Burés Vilaseca 1998), e o reaproveitamento de eventuais cisternas mais antigas durante o período romano republicano é também muito provável em outros contextos (Egea Vivancos 2003; López Castro 2005; Ramallo Asensio e Martín Camino 2015: 132-133).

Por outro lado, a atribuição da construção de algumas das estruturas peninsulares já ao período imperial poderia sugerir uma larga perduração deste tipo de cisternas até períodos relativamente tardios. Casos como os de Zahara de la Sierra (Cobos Rodríguez e Iglesias García 2011), Cerro de la Horca (Ruiz et al. 1990), Ategua (Fortes Santos et al. 2011), Carmona (Conlin Hayes 2001) e possivelmente Ocuri (Guerrero Misa 2009), onde a construção das cisternas a bagnarola se atribuiu já a época imperial, parece apontar nesse sentido.

Esta larga perduração no tempo do modelo em questão pode explicar-se não apenas em função da sobrevivência de uma tradição e de um know-how púnico na Hispania romana - factor que contudo não se deve menosprezar -, mas igualmente pelo facto de algumas estruturas de cronologia segura ou putativamente antiga terem permanecido em uso e/ou sido adaptadas após a conquista romana.

Este fenómeno de reaproveitamento das estruturas hidráulicas está bem documentado na própria metrópole púnica de Cartago, onde a recuperação das cisternas púnicas foi uma das primeiras prioridades após a destruição da cidade na III Guerra Púnica (Wilson 2001).

Na Península Ibérica, a amortização de cisternas do tipo que vimos comentando mais antigas em época imperial está bem documentada em Ampúrias (Burés Vilaseca 1998), em Cástulo (Blázquez et al. 1984), em Lacipo (Puertas Tricas 1982) e em Cádis (Lara Medina 2018: 152). A estes casos vem agora somar-se o do Monte Molião, como veremos seguidamente.

\section{UTILIZAÇÃO, ABANDONO E COLMATAÇÃO DA CISTERNA DO MONTE MOLIÃO: FASEAMENTO, MATERIAIS, CRONOLOGIA}

\subsection{O faseamento da cisterna do Monte Molião: considerações prévias}

A escavação da totalidade dos sedimentos que enchiam a cisterna de Monte Molião, efectuada em 2011 e 2014, permitiu a obtenção de uma estratigrafia (fig. 13), cuja leitura contribuiu para avaliar, do ponto de vista cronológico, as diversas fases de utilização e abandono deste reservatório de água. O faseamento que aqui se apresenta tem por base o estudo detalhado dos materiais arqueológicos que se recuperaram nas várias Unidades Estratigráficas e abarca todos os momentos com ela relacionados, desde a sua construção até à sua última utilização enquanto cisterna, incluindo também os estratos que a colmataram imediatamente após o seu abandono. Excluíram-se desta análise os materiais de um contexto tardio (Fase VII) identificado no topo do enchimento, uma vez que estes foram já publicados (Arruda e Gomes 2013).

Foram identificadas sete fases, sendo, no entanto, muito desigual a informação de que dispomos para cada uma delas. À Fase I, por exemplo, que se refere à construção propriamente dita, não estão directamente associados quaisquer materiais ou artefactos que permitam atribuir-lhe uma cronologia, como, aliás, é habitual em estruturas negativas, escavadas na rocha, como é o caso em apreço. Assim, apenas a arquitectura e os respectivos paralelos tornaram possível uma datação aproximada, que, por outro lado, também é servida pela cronologia dos materiais das Fases II e sobretudo III, ainda de utilização, que lhe fornecem uma datação ante quem. A Fase II, por seu lado, e como já foi referido anteriormente, corresponde a um momento de 


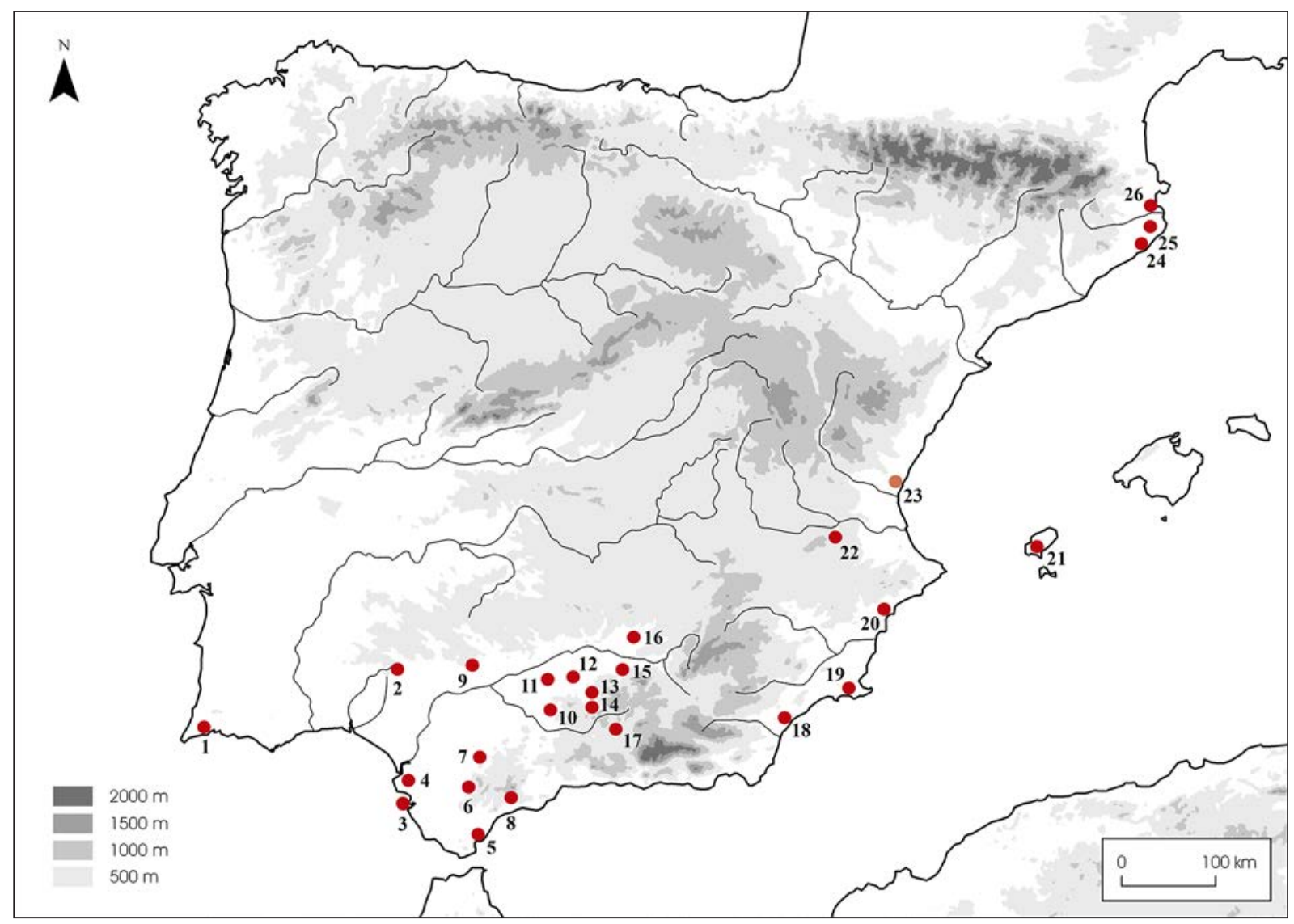

Figura 12. Distribuição das cisternas "a bagnarola" na Península Ibérica: 1 - Monte Molião (Lagos); 2 - Cerro Salomón (Huelva); 3 - Cádis; 4 - Cerro Naranja; 5 - Carteia (Cádis); 6 - Ocuri (Cádis); 7 - Zahara de la Sierra (Cádis); 8 - Lacipo (Málaga); 9 - Carmona (Sevilha); 10 - Monturque (Jáen); 11 - Torreparedones (Córdoba); 12 - Ategua (Córdova); 13 - Cerro de la Cruz de Almedinilla (Córdova); 14 - Cabeza del Obispo (Jáen); 15 - Cerro de la Horca (Jáen); 16 - Cástulo (Jáen); 17 Granada; 18 - Villaricos (Almería); 19 - Cartagena (Múrcia); 20 - Tossal de Manises (Alicante); 21 - Ibiza; 22 - Castellar de Meca (Valência); 23 - Sagunto (?) (Valência); 24 - Castells (Girona); 25 - Ullastret (Girona); 26 - Ampúrias (Girona). Base cartográfica: Trabajos de Prehistoria (CSIC).

manutenção/reparação da cisterna, durante o qual foi repavimentada com opus signinum, que incorporou cerâmicas trituradas (fig. 9). As pastas destas cerâmicas são maioritariamente itálicas o que permite supor que estes trabalhos podem ter sido realizados ainda durante o período romano-republicano.

Os níveis arqueológicos que correspondem quer à utilização (Fase III) quer ao enchimento da estrutura após a sua desactivação (Fases IV - VII) ofereceram materiais arqueológicos, também consideravelmente diferenciados numericamente, que foi possível analisar e estudar devidamente.

Os estratos de base da Fase III, constituídos por sedimentos lodosos, representam o último momento de utilização da estrutura estudada neste trabalho, e os materiais neles encontrados correspondem, certamente, a perdas ocasionais. Não surpreende, portanto que o conjunto artefactual neles recuperado seja limitado a 56 exemplares (todos os valores apresentados neste trabalho dizem respeito ao número total de fragmentos classificáveis, ou seja referem-se ao Número Máximo de Indivíduos [Protocole Beauvray 1998], também chamado Número Tipológico de Indivíduos [Adroher Auroux et al. 2016]), uma vez que se supõe que a cisterna ainda funcionaria como reservatório de água.

A utilização da estrutura como lixeira e a sua colmatação intencional equivale às restantes fases (IV - VI), e os materiais que se registaram nos diversos níveis que as constituem devem ser considerados "descartes" intencionais. Os da fase IV são abundantes - 226 -, o que é compatível com a utilização como lixeira do relativamente extenso e profundo espaço deixado livre após 


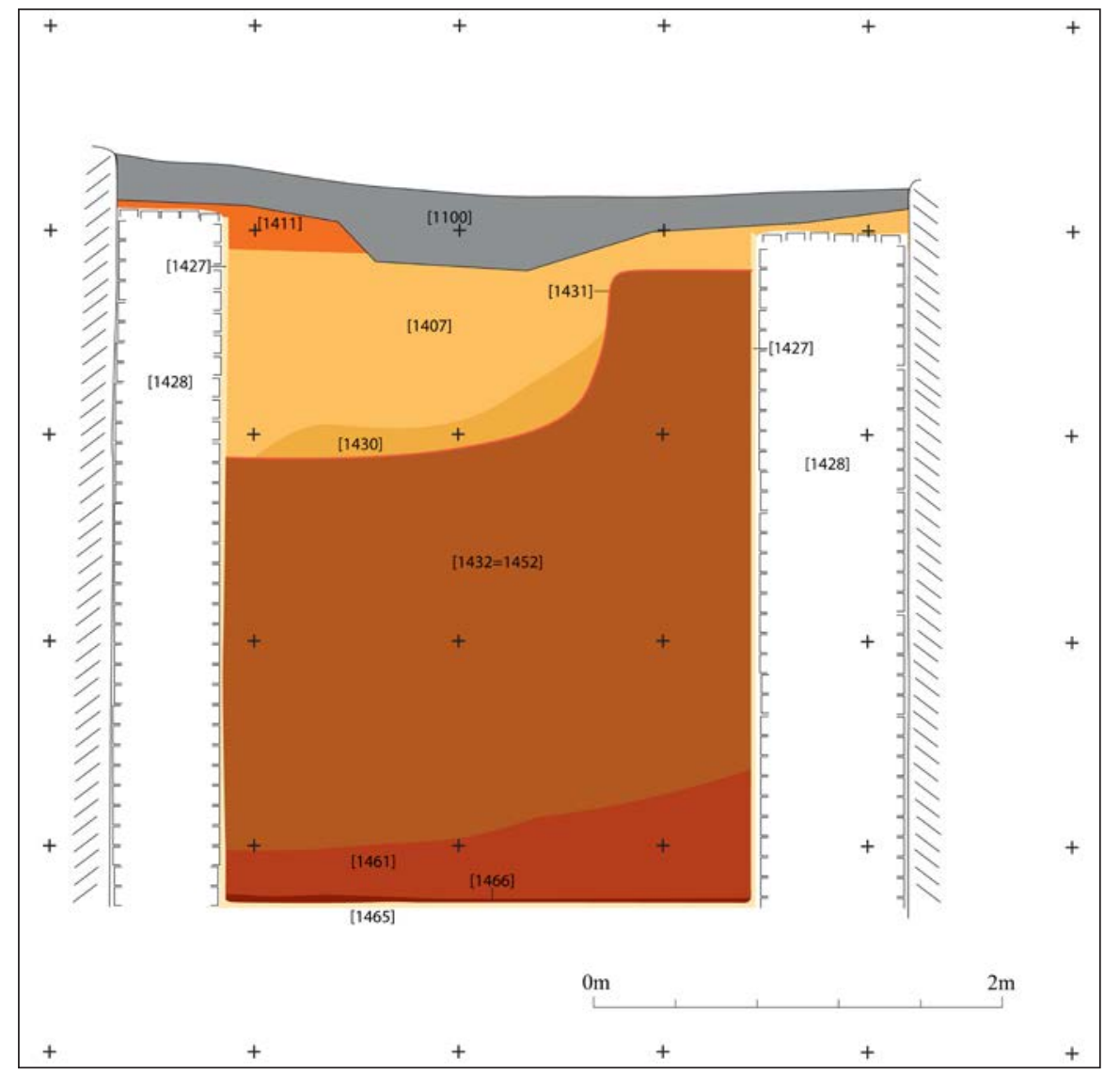

Figura 13. Perfil estratigráfico da secção Norte da cisterna, escavada em 2011; nesta zona, os níveis de Época Romana encontravam-se preservados, não tendo sido afectados pela intervenção do século XIX. a inutilização da cisterna. A Fase V, que fazemos corresponder a um derrube de estruturas que estariam na envolvente imediata, ofereceu um reduzido número de artefactos - 22 -, o que se pode explicar justamente pela formação das respectivas Unidades Estratigráficas. Por fim a grande quantidade de materiais arqueológicas da Fase VI - 248 - não é de estranhar, uma vez que é possível considerarmos que os seus níveis arqueológicos correspondem ao entulhamento que selou, definitivamente, a estrutura negativa aqui estudada.

O conjunto do espólio exumado no interior da cisterna totaliza 924 artefactos (Quadro 1), dos quais somente 552 foram passíveis de integração no faseamento estabelecido. Os restantes foram recolhidos quer no contexto tardio da Fase VII - 138 -, estando aqueles que se encontravam em contexto primário já estudados e publicados detalhadamente (Arruda e Gomes 2013) quer em estratos de revolvimento modernos/contemporâneos que afectaram irremediavelmente a conservação dos depósitos primários (234).

Apenas os materiais que se conservavam em contexto foram estudados de forma aprofundada neste trabalho, sendo apresentados nas páginas seguintes repartidos pelas distintas fases documentadas no enchimento da cisterna.

\subsection{Fase III - a última utilização da cisterna}

Como foi referido, a Fase III corresponde, genericamente, à última utilização da cisterna, integrando unidades que correspondem a níveis de lodos e limos, nos quais se depositaram alguns materiais arqueológicos. Por este motivo, esta fase incorpora sobretudo cerâmicas comuns, a maioria associada ao consumo, recolha e transporte de água, em apreciável estado de conservação. Porém, e embora o conjunto apresente, sobretudo, cerâmicas comuns, foram reconhecidos outros materiais que permitem tecer algumas considerações acerca da cronologia deste momento em que a cisterna ainda era utilizada para a contenção de água.

Infelizmente, nenhum dos quatro fragmentos de ânforas recolhidos permitiu representação gráfica, mas deve, ainda assim, sublinhar-se que três deles 


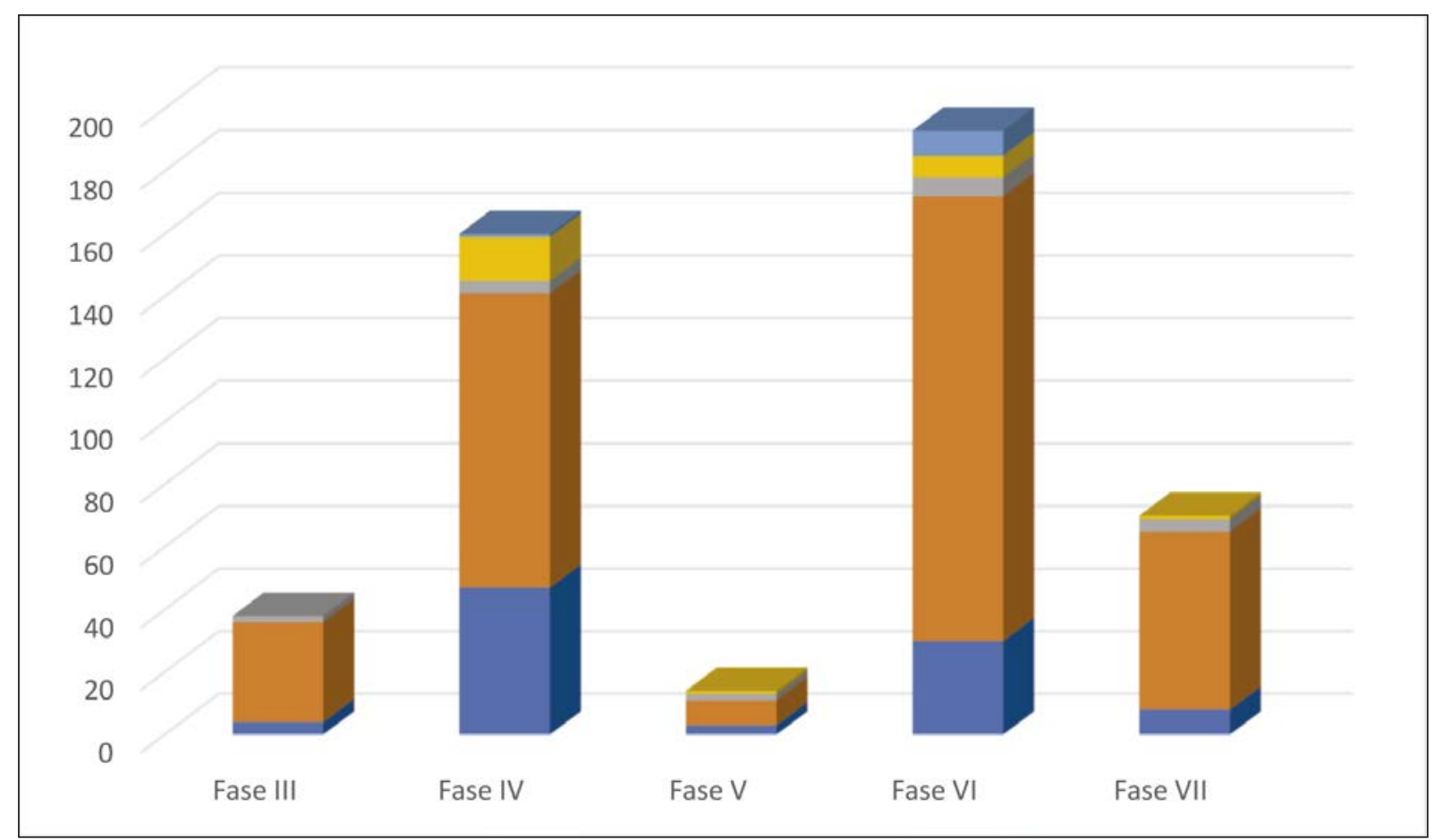

Figura 14. Distribuição das categorias cerâmicas pelas distintas fases de enchimento da cisterna do Monte Molião.

correspondem a produções do vale do Guadalquivir, um dos quais aparenta corresponder a um contentor do tipo Haltern 70. Embora a produção deste tipo anfórico se tenha iniciado no último terço do século I a.n.e. (García Vargas 2000: 67-70; García Vargas et al. 2011) e de o seu fabrico se ter mantido até período tardo-flávio, como parecem comprovar os contextos de La Venta del Carmen, em Cádis (Bernal Casasola e Lorenzo Martínez 1998), o apogeu da sua comercialização pode ser colocado no período augusto-tiberiano. Por outro lado, e como veremos, a sua associação, no mesmo contexto, a outros materiais permite considerar um momento relativamente antigo. A peça restante é um fundo de forma e produção indeterminada.

Apesar de os quatro fragmentos de cerâmica de paredes finas itálica serem de difícil classificação, um deles (fig. 15, $\mathrm{n}^{\mathrm{o}} 1$ ) parece poder incluir-se na forma II de Mayet (1975: 34), cuja correspondência à forma III de Marabini (1973: pl. 3, n. ${ }^{\circ} 26$ e 29) tem sido assumida. Este tipo começou a ser produzido durante o século II a.n.e., mas é aceitável a sua perduração até à segunda metade da centúria seguinte (Marabini 1973: 58; Ricci 1985: 245), tendo-se mesmo proposto que alcance a época de Augusto (López Mullor 1990: 99). Outro fragmento desta mesma categoria cerâmica, correspondente a um fundo (fig. 15, $\mathrm{n}^{\mathrm{o}} 2$ ), foi integrado na forma
III, genericamente datada da segunda metade do século I a.n.e. (Mayet 1975: 29), mais concretamente do seu último terço (Passelac 1993: 513). Merecem particular destaque dois exemplares da forma Mayet VIII, equivalente à forma Ricci 1/193 e 1/194 (fig. 15, nº 3), para a qual se apontou uma datação balizada entre os meados do século I a.n.e. e o período augustano (Mayet 1975: 39). Os contextos de recolha destes exemplares em Monte Molião permitiram, porém, sugerir o início da sua produção em momentos ligeiramente mais recuados (Sousa e Arruda 2018).

A cerâmica comum é a categoria predominante, totalizando 32 fragmentos, dos quais 24 foram passíveis de classificação, distribuindo-se por várias formas que, embora em âmbito doméstico tenham tido distintas funcionalidades, estariam, neste caso, integradas num contexto evidentemente relacionado com a água. Também no que se refere à origem, é grande a diversidade, contando-se com 16 recipientes produzidos na área da Baía de Cádis, 14 do vale do Guadalquivir e apenas um de produção local/regional.

As tigelas são a forma mais bem documentada, representando um terço da totalidade de peças de cerâmica comum. Dos dez exemplares, cinco são originários da Bética costeira (fig. 15, $\mathrm{n}^{\circ} 4$ a 7) e os restantes do vale do Guadalquivir (fig. 15, $n^{\circ} 8$ a 11). São recipientes 
polivalentes, mas tem sido destacada a sua utilização, sobretudo, para beber (Girón Anguiozar 2017: 318), o que permite admitir o consumo de água no local. Apresentam uma considerável variedade morfológica, situação que, apesar de tudo, não é critério de diferenciação cronológica ou funcional. Os exemplares recolhidos nos estratos da Fase III possuem bordo aplanado ou reentrante, sem evidente tratamento das superfícies, que se apresentam meramente alisadas, e integram-se na forma 17 da tipologia elaborada para a Baía de Cádis (Girón Anguiozar 2017: 318-320), à qual é atribuída uma cronologia que abrange toda a época romana-republicana e alto-imperial. São todos da variante 1, maioritariamente da sub-variante a), reconhecendo-se alguns da e), tipo que foi já descrito e caracterizado para os contextos deste sítio algarvio (Sousa e Arruda 2014). Destacamos particularmente um dos exemplares, de perfil completo (fig. 15, $n^{\circ} 4$ ), que encontra paralelo numa peça publicada por Enrique García Vargas e Ester López Rosendo (2008: 305, Fig. 17, no 1 ) da figlina de Rabatún, em Jerez de la Frontera, atribuída à primeira fase de produção da oficina, datada genericamente entre 20 a.n.e. e 20 (García Vargas e López Rosendo 2008: 308).

Cinco outras tigelas têm origem no vale do Guadalquivir, sendo passíveis de inclusão no tipo 2.4 da tipologia de María Victoria Peinado (2010: 137-138), realizada a partir do conjunto cerâmico produzido nos fornos de Los Villares de Andújar.

Um fragmento com características de fabrico que permitem considerá-lo oriundo do vale do Guadalquivir foi reconhecido como taça, forma que distinguimos da anterior, já que o seu diâmetro de bordo é inferior ao diâmetro máximo. A presença desta forma nos sítios romanos do Algarve não é uma novidade, pois foi já reconhecida em outros sítios e em outros contextos (Pereira 2018: 102).

Embora menos frequentes na Fase III, os potes oferecem uma maior diversidade formal, mas não quanto à origem, pois apenas um é proveniente das figlinae litorais da Bética, enquanto os restantes cinco foram fabricados nas do vale do Guadalquivir.

Nos estratos da Fase III identificámos um exemplar produzido no vale do Guadalquivir (fig. 15, no 12), do tipo 3.1 de Peinado (2010: 148-150), que tem equivalência no 13.5 da tipologia elaborada para as cerâmicas comuns da Bética litoral (Girón Anguiozar 2017: 247253). Este tipo em concreto tem correspondência com a forma 1.2 de Mercedes Vegas (1973:11-12) e é frequente, sobretudo, nos sítios do litoral da Bética, como parece ser o caso de Jardín de Cano, em El Puerto de
Santa María (López Rosendo 2008), ou Los Prados, em Jerez de la Frontera (Girón Anguiozar 2017: 253). Segundo os contextos onde tem vindo a ser identificado, tem-lhe sido atribuído uma cronologia entre o século I a.n.e. e o final do II (Ibidem).

Apesar de algumas diferenças, incluímos na mesma forma outros dois exemplares (fig. 15, $n^{\circ} 13$ e 14; fig. $16, \mathrm{n}^{\mathrm{o}} 1$ ), que cabem, no entanto, em outra variante, concretamente a 13.14 da tipologia de Lourdes Girón (2017: 260-261). Ambos, contudo, exibem pastas que permitem considerá-los produções do vale do Guadalquivir. Este tipo de potes, de perfil globular, colo curto e cilíndrico ligeiramente exvertido, bordo engrossado no exterior de perfil triangular e fundo côncavo, é frequente nessa área também em contexto funerário (López de la Orden 2003: 112-113, fig. 1, no 4) e pode-se atribuir-lhe uma cronologia idêntica à da forma anteriormente abordada. Tanto nas produções das figlinae litorais como nas das que se localizariam mais para o interior, este tipo apresenta frequentemente, na superfície exterior, pintura em bandas horizontais, o que também foi reconhecido em três peças deste conjunto de Monte Molião, dois provenientes da Bética costeira (fig. 16, $\mathrm{n}^{\mathrm{o}} 2$ ) e o restante do vale do Guadalquivir.

Embora estas formas sejam genericamente denominadas "potes" e como tal consideradas quanto à sua funcionalidade, a verdade é que a sua diversidade morfológica é relativamente grande. Alguns recipientes incluíveis nesta categoria formal podem ser considerados urcei, vasos que, segundo fontes clássicas (Girón Anguiozar 2017: 41-42), se utilizavam, entre outras funções, para conter água. Deve chamar-se desde já aqui a atenção para o facto de não se tratar do recipiente que, há pouco anos, Rui Morais designou de "tipo urceus" (Morais 2007), mas sim de outra forma, que a autora da tipologia construída para a cerâmica comum da Bética costeira, que aqui seguimos, denominou de urceus.

Este tipo específico de potes possui duas asas em fita, corpo globular, bocal largo e bordo invertido, aplanado no exterior (Pinto e Morais 2007: 241-242). No lado interno, o bordo apresenta sempre uma depressão, mais ou menos acentuada, que se destinava ao encaixe de uma tampa. A base pode ser plana, por vezes com uma saliência lateral, mas são igualmente frequentes os fundos simples com pé indicado e base plana. A cronologia avançada para esta forma é confirmada pelas características e contextos associados a estes recipientes, frequentemente funerários (Pereira 2018: 115), os quais terão sido particularmente predominantes durante a segunda metade do século I e a primeira do II (Vegas 1973: 113-117). Todavia, a datação do início da 


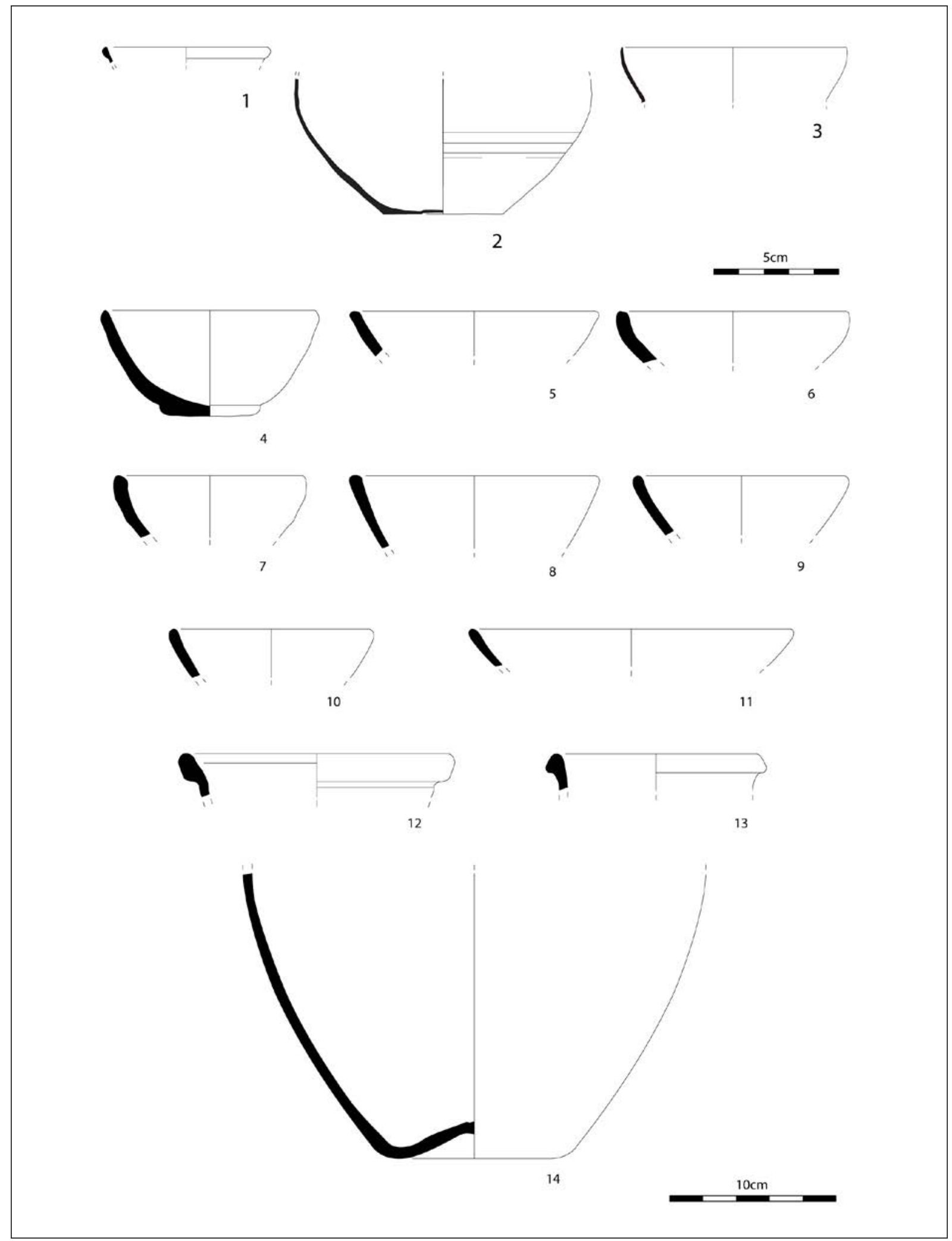

Figura 15. Materiais da Fase III da cisterna de Monte Molião. No 1 a 3 - cerâmica de Paredes Finas; № 4 a 14 - Cerâmica comum. 
sua produção pode ser mais antiga (Girón Anguiozar 2017: 332), como ficou provado na Calle Troilo de Cádis (Sáez Romero 2008: 519). O tipo integra a forma 18 da tipologia de Lourdes Girón (2017: 329-333), correspondendo a maioria dos exemplares de Monte Molião à variante 18.1 (fig. 16, no 3 e 4), forma que a autora considera plurifuncional, mas especialmente vocacionada para o transporte. Para tal hipótese muito contribuíram as considerações de Ponsich e Tarradel (1965: 65-68, fig. 40), que consideraram que em Cotta, em Marrocos, a forma estava relacionada com o transporte de garum. Em outros sítios, como é o caso de Ostia, a mesma foi associada à conservação de alimentos, a partir de início do século I (Pavolini 2000: 203). O contexto do seu aparecimento em Monte Molião deve, portanto, ser devidamente valorizado, apesar da sua presença em ambientes funerários algarvios também estar documentada (Pereira 2018: 102-103).

Os púcaros estão também presentes na fase mais antiga de enchimento da cisterna. Embora apenas tenha sido recolhido um exemplar neste contexto (fig. 17, $\mathrm{n}^{\mathrm{o}}$ 1), a forma associa-se igualmente à ingestão de líquidos, entre eles a água. Tal como foi já referido, as fontes clássicas fornecem esclarecedoras passagens acerca do uso destes recipientes (lagoenae), especificamente para o consumo do vinho (Séneca, Epistolae, CXVIII, 15) e da água (Columela, De Re Rustica, XII, 11). Este tipo, classificado por Lourdes Girón como forma 11 (Girón Aguiozar 2017: 195-200), apresenta, nessa tipologia, uma grande variedade de subtipos, situação que se relaciona com o facto de a autora reunir nesta forma recipientes que podem ter tido funções distintas. O exemplar lacobrigense apresenta perfil piriforme, carena bem marcada nas faces interna e externa na metade inferior do corpo, colo inexistente, bordo ligeiramente encurvado e base simples (Girón Anguiozar 2017: 209-211). Frequentemente, estes recipientes estão munidos de uma asa, que arranca do bordo ou imediatamente abaixo dele, nos das figlinae do litoral bético, e da parte inferior do bordo nos fabricados no Alto Guadalquivir (Peinado Espinosa 2010: 215, fig. 4.24). A forma, equivalente ao tipo 44.4 de Mercedes Vegas (1973: 102-103), apresenta uma cronologia bastante dilatada, desde o século II a.n.e. até ao III (Girón Anguiozar 2017: 211). Porém, parece evidente uma evolução formal dentro deste tipo em concreto, cujos exemplares mais antigos se inspiram nos modelos metálicos de tipo Piatra Neamt (Py 2016, tipo BB-1531), facto que pode justificar a ampla difusão destes púcaros por todo o Mediterrâneo (Vegas 1973: 103). É o caso do exemplar que agora se dá à estampa, que ostenta fortes semelhanças com aqueles recipientes metálicos, pelo que parece credível atribuir-lhe uma cronologia antiga, coeva da dos outros materiais antes abordados, que consideramos produções tardo-republicanas ou augustanas.

Também os jarros estão relacionados com a manipulação de líquidos, embora possamos admitir que algumas formas em concreto possam ter sido utilizadas para a ingestão destes. É o caso concreto da forma 11.18 (Girón Anguiozar 2017: 218-219), de que se reconheceu um exemplar (fig. 17, $\mathrm{n}^{\mathrm{o}} 2$ ) integrável na variante b), tipo de recipiente por vezes dotado de uma asa de apoio para o polegar. Estes recipientes ostentam paredes encurvadas, perfis piriformes ou elípticos, terminando em bases simples, umbilicadas. O bordo é exvertido, de forma quadrangular e, por vezes, moldurado. Este tipo de jarros assemelha-se ao tipo 43.1 de Mercedes Vegas (1973: 100-103), para o qual a autora propõe uma cronologia entre a viragem da Era e o século IV. Outros autores, porém, já sublinharam a maior presença desta forma em contextos alto-imperiais, admitindo o seu fabrico e utilização desde o último quartel do século I a.n.e. (Girón Anguiozar 2017: 219).

Outros dois exemplares (fig. 17, nº 3 e 4) são passíveis de integração na mesma forma, mas as características das suas pastas indicam uma área de produção localizada no vale do Guadalquivir. São recipientes globulares, de paredes curvas, colo indiferenciado do corpo, base simples, plana, por vezes convexa - como é o caso em apreço - e bordos aplanados. É frequente a presença de uma asa. Este tipo tem paralelo com a forma 348 de Santrot e Santrot (1979: 162), documentada sobretudo em contextos do século I.

Embora não possam ser relacionadas de forma clara com o consumo ou transporte de água, as tampas funcionaram como elementos que se podem associar aos restantes recipientes, até porque a coincidência entre os diâmetros é notória em, pelo menos, um dos casos (fig. 17, $\mathrm{n}^{\mathrm{o}}$ 5). Foram reconhecidos dois exemplares, um produzido no vale do Guadalquivir, sendo outro de produção local/regional.

Ainda integrável no grupo da cerâmica comum, identificou-se um fragmento inclassificável de cerâmica de engobe vermelho pompeiano, parecendo corresponder ao fundo plano, revestido, no interior, por um engobe espesso, que não parece corresponder a uma produção itálica. As questões acerca da imitação desta categoria de cerâmica itálica foram já abordadas por outros autores (Arruda e Viegas 2002: 222-223; Girón Anguiozar e Costa García 2009), pelo que nos dispensamos de aprofundar a temática. Ainda assim, 


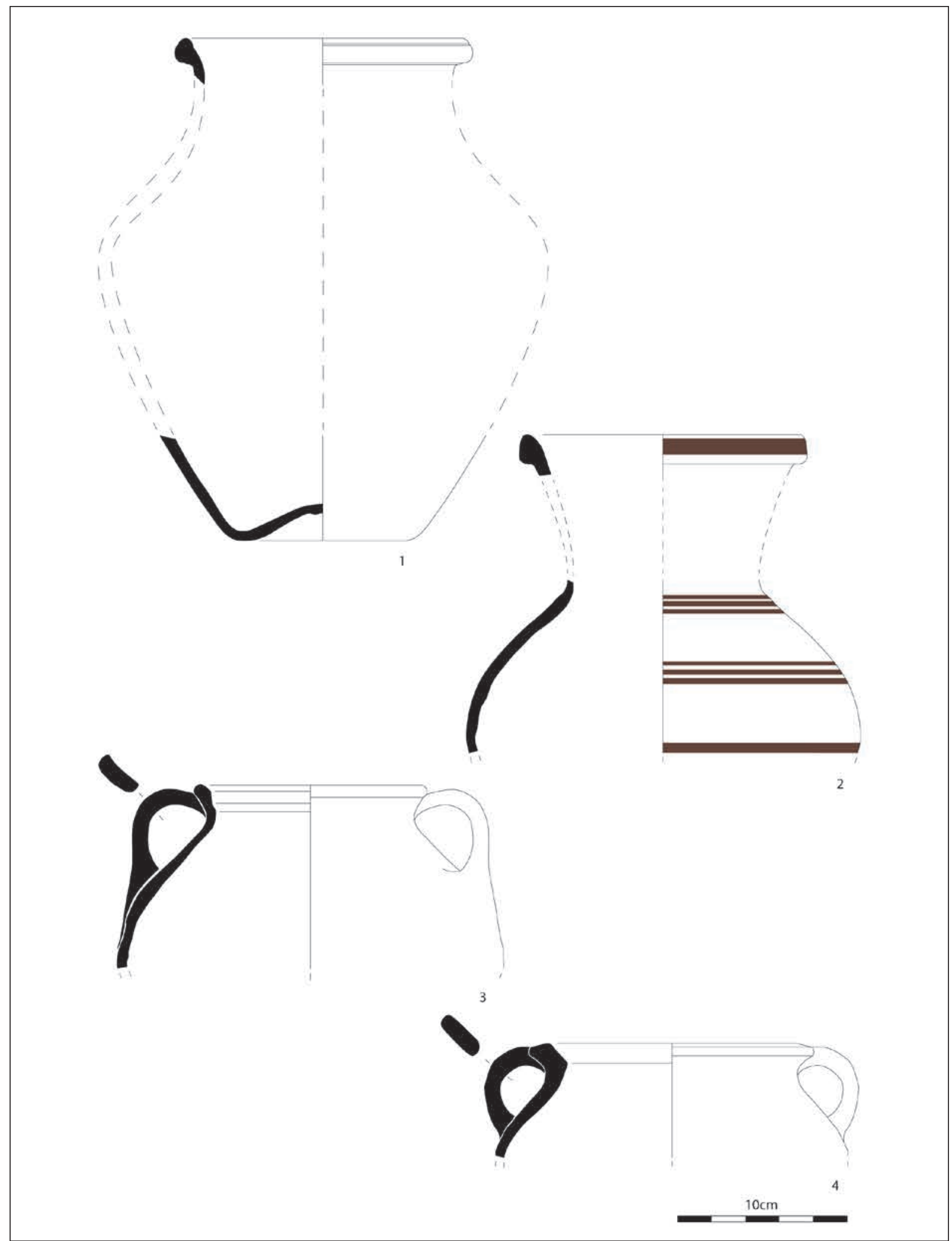

Figura 16. Materiais da Fase III da cisterna de Monte Molião. Cerâmica comum e pintada. 
é conveniente lembrar que estas "imitações" estão documentadas em outros sítios do território actualmente português, concretamente em Braga (Delgado 1994), em Coimbra (Carvalho 1998), em Conímbriga (Alarcão 1975) e na Cidade das Rosas, Serpa (Caeiro 1978). No Ocidente Peninsular, estas produções estão predominantemente atestadas durante o principado de Augusto (Aguarod Otal 1991: 58).

Merece ainda destaque a presença de outras peças, que, infelizmente, não permitem grandes considerações, por se apresentarem bastante fragmentadas ou por não facultarem datações precisas. É o caso de um fragmento de lucerna inclassificável e de nove artefactos metálicos. Destes últimos, a maioria integra a categoria de elementos utilitários (pregos), que podem ter sido utilizados em estrutura mecânica de extracção da água do interior da cisterna ou numa eventual cobertura.

O conjunto inclui ainda um fragmento de unguentário (fig. $17, \mathrm{n}^{\mathrm{o}} 6$ ), com revestimento interno de tonalidade negra, idêntico aos do Grupo B de Cuadrado (1977-1978; v. tb. Py 1993) ou do Grupo C de Muñóz Vicente (1987), particularmente dos datados dos dois últimos séculos antes da viragem da Era, sem que reconheçamos um inequívoco paralelismo com qualquer das variantes. Tal como foi considerado para outros exemplares algarvios (Pereira 2018: 115-116), pode tratar-se de uma produção avançada dentro desta série, eventualmente das últimas décadas do século I a.n.e., ou da primeira metade da centúria seguinte.

\subsection{Fase IV: utilização pontual como lixeira}

Os níveis desta fase, correspondente a um momento em que a cisterna terá sido utilizada como lixeira, permitiram a recolha de um total de 226 artefactos, distribuíveis por várias categorias. Destas, as mais numerosas são as ânforas (48) e as cerâmicas comuns (94). Destaque-se ainda uma considerável quantidade de cerâmicas de paredes finas (21), de cerâmicas campanienses (14) e de artefactos metálicos (31).

Das 48 ânforas, 10 não permitiram classificação. As restantes ostentam pastas que delatam produções béticas, itálicas, norte-africanas e lusitanas. As primeiras incluem produções do vale do Guadalquivir (25) e do litoral (oito) (Arruda e Viegas 2016). Da primeira região, registaram-se 17 ânforas de tipo Haltern 70 (fig. 18, $n^{\circ}$ 1-6) correspondentes, sobretudo, à "versão clássica" (Arruda e Viegas 2016: Fig. 5, no 5 e 7 e Fig. 6 no 1 e 9), datável desde Augusto a Calígula (Berni 2011: 80-107); uma da Classe 67, cuja produção está documentada, até ao momento, apenas em El Rinconcillo (García Vargas et al. 2011: 260-261), o que permitiu fixar o início da sua produção em momento central do segundo terço do século I a.n.e.; duas de tipo Oberaden 83 (fig. 19, $\mathrm{n}^{\mathrm{o}} 1$ e 2), cuja produção se prolonga até um momento indeterminado em torno à viragem da Era (García Vargas et al. 2011: 237-238); duas Dressel 7/11(fig. 18, nº 9) (Arruda e Viegas 2016: 449, fig. 6, $\mathrm{n}^{\circ} 11$ ), que se assemelham às Dressel 7, forma que García Vargas considerou o único tipo dentro daquele grupo a ser produzido no baixo Guadalquivir (2000, fig. 6, n. ${ }^{\circ} 10-13$ ).

As produções lusitanas são aqui muito escassas. Das sete contabilizadas, duas correspondem a fragmentos inclassificáveis. Das restantes, três pertencem à forma Haltern 70 (fig. 18, n 7 e 8 ) e ostentam pastas que foram atribuídas ao Algarve ocidental (Arruda e Viegas 2016: 458, fig. 10, $\mathrm{n}^{\circ} 1-2$ ).

Duas asas podem ter pertencido a ânfora(s) Dressel 14, não permitindo grandes considerações (Arruda e Viegas 2016: 460), devendo, ainda assim, recordar-se que estes são os recipientes mais tardios neste contexto, mesmo admitindo que possam corresponder a importações dos vales do Tejo ou Sado, onde os mais antigos indícios da sua produção podem recuar até ao início do segundo quartel do século I (Silva 1996).

Além destes contentores anfóricos, outros foram reconhecidos, mas tudo indica que correspondem a material residual, representando 19\% desta categoria (nove exemplares). Trata-se de ânforas de tipo D de Pellicer, da baía gaditana, Dressel 1 itálicas e Mañá C2 (T. 7.4.3.1 e 7.4.3.3.) norte-africanas e gaditanas. Estes contentores oferecem datações anteriores à que se atribui a este contexto concreto e, como tal, poderão resultar de sedimentos que teriam a finalidade de selar os lixos atirados para o interior da estrutura hidráulica.

A terra sigillata itálica está presente em quantidades reduzidas, tendo sido contabilizados seis fragmentos, dos quais apenas três permitiram classificação (Arruda e Dias 2018). Os pratos de paredes baixas, convexas e fundo plano da forma Consp. 4 registam-se na sua variante mais simples (fig. 19, $\mathrm{n}^{\mathbf{0}} 3$ ), que pode ser datada de um momento anterior à fundação de Oberaden (Ettlinger et al. 1990: 58). Foram também reconhecidos recipientes que integravam o serviço II de Haltern, as taças de tipo Consp. 22 (fig. 19, n 5), apresentando uma forma cónica com o bordo vertical, côncavo e com decoração externa em guilhoché (Ibidem). A forma Consp. 23.2 corresponde igualmente a uma taça que resulta da evolução da forma anterior. Esta variante foi datada de meados do século I (Ettlinger et al. 1990: 92). 


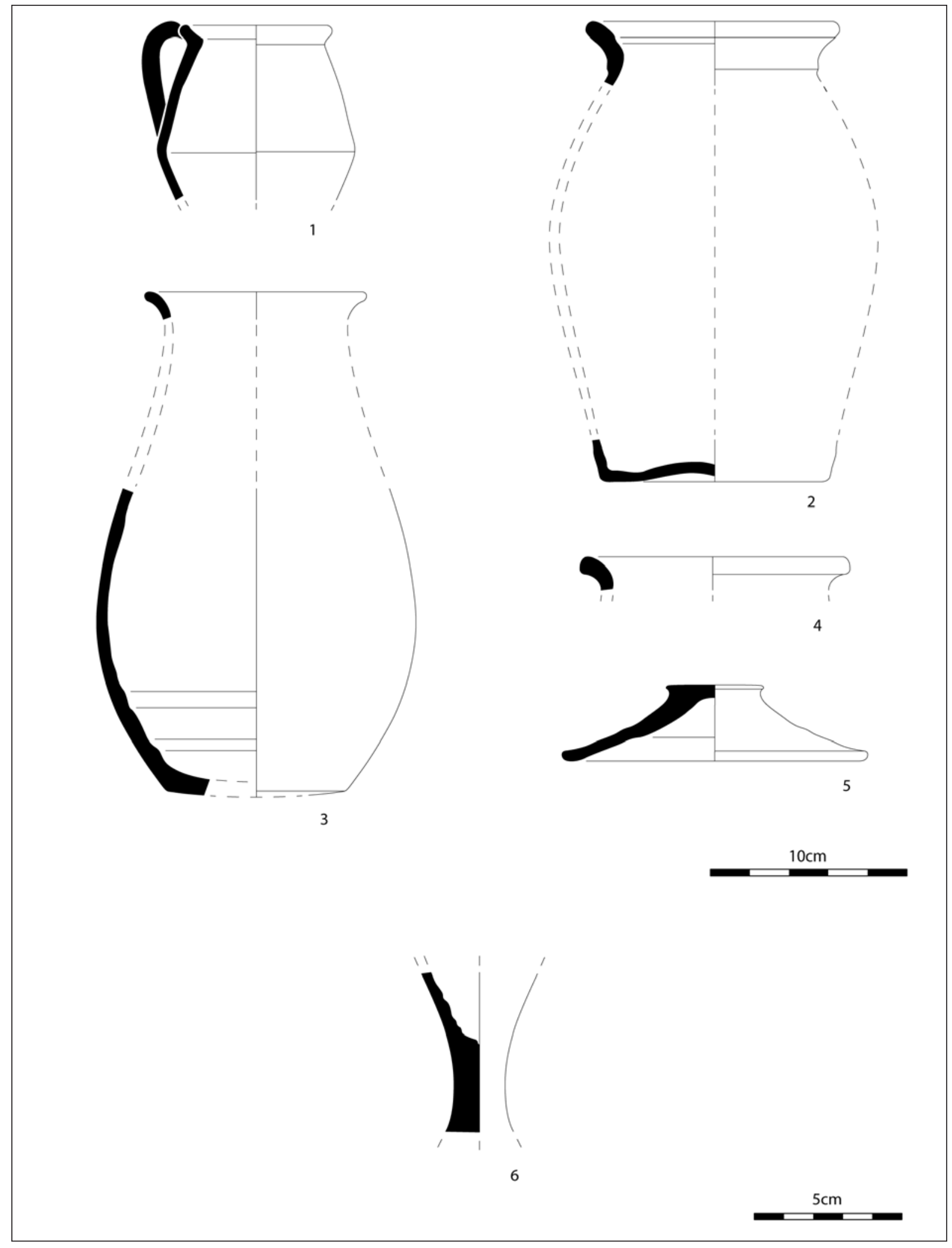

Figura 17. Materiais da Fase III da cisterna de Monte Molião. № 1 a 5 - Cerâmica comum; № 6 - Unguentário de cerâmica. 
A única peça de terra sigillata sudgálica destaca-se pelo estado de conservação e também pelo facto de corresponder a uma produção antiga, ainda de "tipo itálico" (fig. 19, $\mathrm{n}^{\circ}$ 4). Trata-se de uma forma Consp. 22 (Ettlinger et al. 1990: 90-91), sem se tornar possível distinguir a variante uma vez que não dispomos de lábio. No fundo interno, está impressa a marca L. PACONIUS, em cartela quadrangular. Quer a forma, quer a marca, quer o próprio fabrico indicam uma origem nas oficinas de Montans, correspondendo aos primeiros produtos aí fabricados, até porque o oleiro é, segundo Martin (2001: 231), um dos pioneiros na produção destes recipientes nesta área geográfica, muito concretamente na primeira década do século I.

A terra sigillata hispânica soma apenas dois fragmentos que, infelizmente, não permitiram classificação. Todavia, atendendo ao facto de ambos ostentarem características tecno-petrográficas que permitem a sua inclusão no grupo da terra sigillata hispânica precoce, não parece descabido supor que se trate de produções coetâneas à dos restantes materiais.

A cerâmica de paredes finas é relativamente abundante nos estratos da Fase IV da cisterna de Monte Molião, totalizando 21 fragmentos. Todavia, como é habitual nesta cerâmica, o elevado estado de fragmentação não permitiu a classificação da maioria deles.

A forma mais frequente é a VIII de Mayet (13 fragmentos), (fig. 19, $\mathrm{n}^{\circ} 6$ e 7) equivalente ao tipo Ricci $1 / 193$, com perfis arqueados, bordos altos e paredes muito finas, aproximando-se dos da variante VIII C daquela investigadora francesa (Mayet 1975: 39), 12 dos quais apresentam pastas muito semelhantes aos exemplares de produção itálica (Sousa e Arruda 2018: Grupo 2). O restante ostenta uma pasta de difícil adscrição geográfica, mas que pode integrar uma produção meridional. Destacam-se ainda dois bordos (fig. 19, $\mathrm{n}^{\circ}$ 8), exvertidos e engrossados, que podem corresponder à forma XXXI de Marabini, com equivalência no tipo Ricci 1/59, produzida entre o século II a.n.e. e o período augustano (Marabini 1973: 100-101; Ricci 1985: 257).

Os estratos desta fase incluem ainda 14 vasos de cerâmica campaniense, com características que acusam origens napolitanas (um) e calenas (dois). Porém, a maioria do conjunto insere-se nas chamadas imitações de campaniense itálica de pastas cinzentas. Os recipientes itálicos encontram paralelo em exemplares da forma Lamb. 27/F. 2831 (fig. 19, no 10), no caso do exemplar napolitano, Lamb. 8/F. 2311 (fig. 19, n $^{\circ} 11$ ) e Lamboglia 5/7/F. 2275b (fig. 19, $\mathrm{n}^{\circ} 12$ ), no caso das produções calenas. Porém, nenhuma destas produções deverá ter perdurado até aos primeiros decénios após a viragem da Era, o que nos obriga a considerá-los materiais residuais. Mais numerosa é a cerâmica campaniense de pasta cinzenta, representada por um total de 11 fragmentos, dos quais apenas seis são classificáveis, integrando-se na forma 5/7 de Lamboglia (fig. 19, no 13 e 14). Estes fabricos têm vindo a adquirir cada vez mais relevância nos conjuntos desta categoria, não sendo o de Monte Molião excepção (Dias 2010; 2015). De facto, e no caso dos conjuntos do Ocidente, foi proposta uma difusão entre meados do século I a.n.e. e princípio do principado de Augusto (Alves et al. 2014: 173), sendo anterior em outras áreas da Península Ibérica (Roca e Principal 2007; Revilla e Roca 2010). No entanto, outros autores alertaram já para o facto de ser difícil tentar estabelecer um momento rígido para o final destas produções do vale do Guadalquivir, propondo que a sua amortização possa, inclusive, prolongar-se após o principado de Augusto (Ruiz Montes e Peinado Espinosa 2012: 124), como alguns casos parecem comprovar (Adroher Auroux et al. 2001; Berrocal Rangel e Ruiz Triviño 2003: 127). Por outro lado, tudo indica que estas produções subsistem, efectivamente, após a viragem da Era, até porque vasos com pastas e acabamentos com estas mesmas características "imitam" formas de outras categorias cerâmicas, nomeadamente a terra sigillata itálica, como acontece no Patio de Banderas do Real Alcázar de Sevilha, onde estão documentadas na $1^{\text {a }}$ fase imperial, datada entre 15 a.n.e. e 35 (Ramos Suárez e García Vargas 2014: 144-146), tornando possível propor uma cronologia de meados do século I para o final da produção da "cerámica gris bruñida republicana", quando copiam formas de terra sigillata (Adroher Auroux 2014: 287).

A cerâmica comum, alguma pintada, é abundante nesta fase. No total, contabilizaram-se 97 fragmentos, dos quais 27 não permitiram classificação. As produções identificadas delatam origens itálicas (dois), béticas costeiras (71), béticas do Guadalquivir (18) e também, em alguns casos, locais/regionais (sete). $\mathrm{O}$ repertório formal é variado, notando-se agora a presença de formas abertas, como alguidares, almofarizes ou pratos.

Os alguidares estão representados neste contexto apenas por três bordos (fig. $20, \mathrm{n}^{\circ} 1$ a 3 ), todos produzidos no vale do Guadalquivir. São recipientes plurifuncionais, que podiam, segundo as fontes clássicas (Varrão, De Lingua Latina V: 119; Celso, De Medicina IV: 31 ), servir para lavar e preparar alimentos ou mesmo ser utilizados na higiene pessoal. Independentemente da função, este recipiente parece ter estado sempre relacionado com a água (Girón Anguiozar 2017: 39). Embora as características tecno-petrográficas 


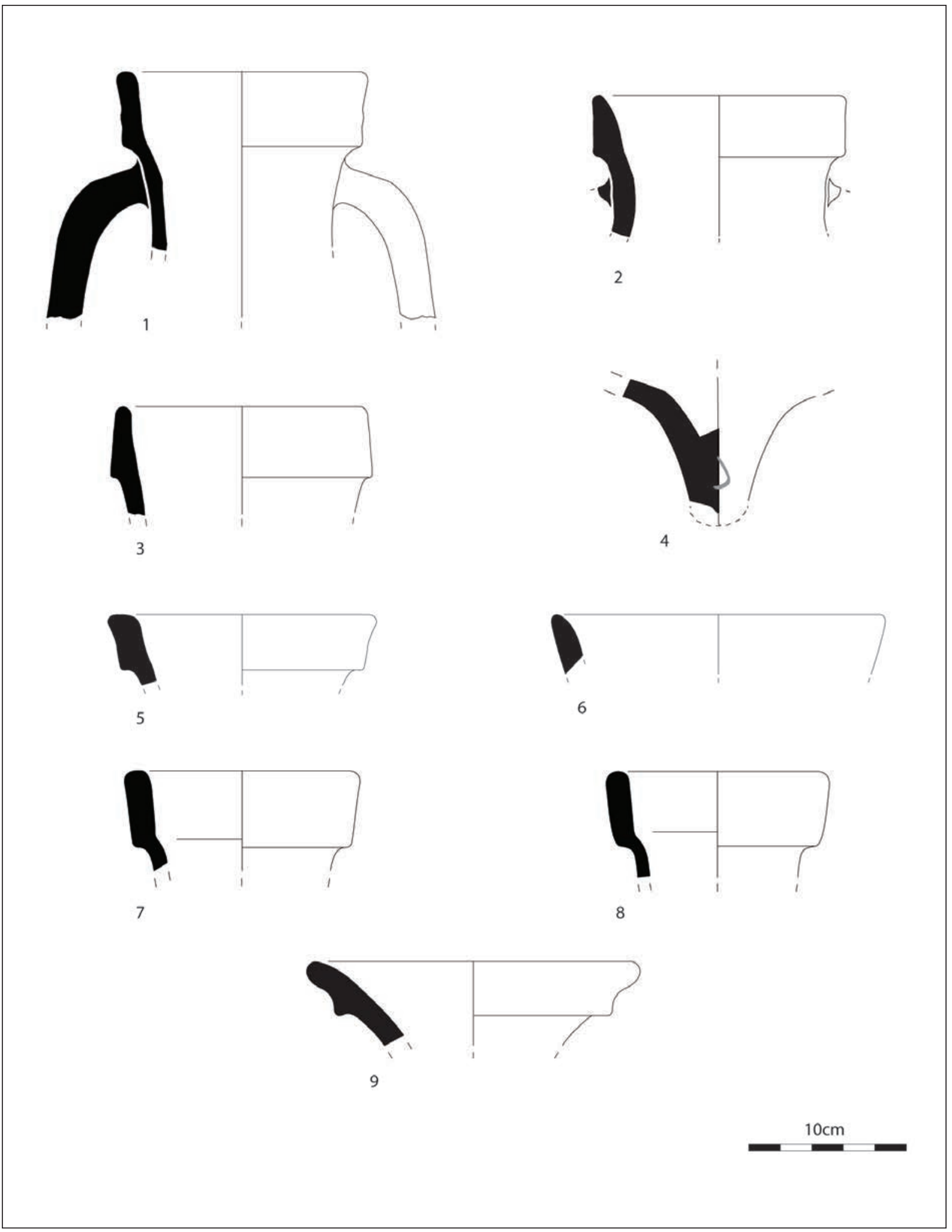

Figura 18. Materiais da Fase IV da cisterna de Monte Molião (desenhos de Catarina Viegas, adaptado). № 1 a 6 - Ânforas Haltern 70 do vale do Guadalquivir; 7 e 8 - Ânforas Haltern 70 de produção lusitana; 9 - Ânfora Dressel 7/11 do baixo Guadalquivir. 
remetam claramente para as figlinae do Guadalquivir, parece sensato supor que estas se localizariam na área mais próxima do litoral, sobretudo se tivermos em consideração que a morfologia dos exemplares lacobrigenses se aproxima dos aí fabricados, especificamente dos da forma 16 (Girón Anguiozar 2017: 316-317), e não encontra paralelos nos do Alto Guadalquivir (Peinado Espinosa 2010). Estes vasos, caracterizados por perfis semiesféricos, bordos verticais ou ligeiramente oblíquos, engrossados, moldurados e com bases simples, oferecem cronologias contextuais bastante amplas, estando já incluídos nas tipologias cerâmicas do final da Idade do Ferro e início da República (Sáez Romero 2005), sabendo-se que perduram até ao século I (Girón Anguiozar 2017: 316). Um dos exemplares (fig. 20, $n^{\circ} 3$ ), porém, ostenta uma morfologia atípica, situação que obriga a ponderar a eventualidade de corresponder a um recipiente distinto, porventura do tipo que María Victoria Peinado denominou de COC-RED 1.1 (Peinado Espinosa 2010: 151). Por outro lado, um alguidar idêntico, de bordo engrossado internamente, foi identificado nos contextos da Fase 4 do Patio de Banderas, em Sevilha, datada de 60-90 (Vázquez Paz et al. 2018: 139-142, fig. 7, no 1).

Claramente relacionados com a preparação de alimentos são os almofarizes. Nos níveis desta fase, foi identificado um total de oito fragmentos, dos quais três não permitiram considerações tipológicas. Dos restantes, dois foram produzidos na área da Bética costeira (fig. 20, no 4 e 5) e três no vale do Guadalquivir (fig. 20, $\mathrm{n}^{\mathrm{o}} 6$ a 8). Infelizmente, apenas podemos incluir estas peças, genericamente, na forma COM-RO-BET 2.1 estabelecida por María Victoria Peinado (2010: 135). Não obstante, um dos almofarizes, importado da Bética costeira (fig. 20, $\mathrm{n}^{\mathrm{o}} 4$ ), permitiu estabelecer paralelos tipológicos com a forma 12.3.b de Lourdes Girón (2017: 241-243). Trata-se de um tipo bastante comum, sobretudo na área meridional, com datações compreendidas entre a viragem da Era e final do século II, como exemplares de El Palomar (Montero et al. 2008: 85), de Pinar de Villanueva (Bejarano 2009: 178) ou da capital gaditana (Girón Anguiozar 2013: 1768) parecem comprovar. Embora em território nacional alguns destes recipientes tenham sido datados a partir do final do século I a.n.e. (Pinto e Morais 2007: 239), é interessante constatar que perduram em alguns contextos hídricos, em níveis de amortização, até ao século IV (Girón Anguiozar 2017: 242).

Outro almofariz bético (fig. 20, n $n^{\circ}$ ) apresenta um perfil consideravelmente distinto do anterior que, embora encontre paralelo na forma 12.8 de Lourdes Girón
(2017: 246) ou na 7.7 de Mercedes Vegas (1973: 3033), parece ajustar-se melhor ao que Alessandro Quercia identificou como alguidares, concretamente ao tipo 12b (Quercia 2004: 208-209). Porém, as ranhuras marcadas na superfície interna obrigaram à sua classificação como almofariz, seguindo, aliás, as propostas da investigadora espanhola. Ainda que os modelos itálicos tenham uma origem significativamente anterior, os seus congéneres béticos têm sido considerados produções vigentes a partir de um momento indeterminado da primeira metade do século I (Santrot e Santrot 1979: 110-111).

As taças e as tigelas somam um total de 15 fragmentos, distribuídos por produções do vale do Guadalquivir (três, fig. 21, $\mathrm{n}^{\mathrm{o}} 1 \mathrm{e}$ 2), da Bética costeira (10, fig. 21, $\mathrm{n}^{\circ} 3$ e 11) e locais/regionais (dois). Geralmente apresentam bordo engrossado internamente e estão perfeitamente documentadas por todo o Algarve em contextos habitacionais do século I e primeira metade do século II. São recipientes polivalentes, admitindo-se que a sua função principal seria a de beber e, como tal, de uso pessoal. A grande maioria integra-se na forma 17.1 de Lourdes Girón (2017: 318-320), o tipo 21.1 de Mercedes Vegas (1973: 58), as formas 113 e 114 de Marie-Helène e Jacques Santrot (1979: 87) ou o tipo III de Inês Vaz Pinto (2003: 226-229). A sua simplicidade morfológica confere-lhes uma considerável longevidade, desde a República até à Antiguidade Tardia.

Um outro recipiente de produção bética (fig. 21, $\left.n^{\circ} 12\right)$ merece destaque, pela sua morfologia particular, e também pela própria integração tipológica, que, neste caso, tem igualmente consequências directas em termos cronológicos. Alguns trabalhos incluem esta forma na grande categoria das tigelas (Girón Anguiozar 2017: 325-326, forma 17.8), mas outros autores consideram que corresponde a recipientes de tipo terrina (Pinto 2002; Pinto e Morais: 2005: 241). Porém, esta mesma forma foi reconhecida no próprio sítio de Monte Molião tanto em níveis da Idade do Ferro (Arruda et al. 2008: 173-174; Arruda et al. 2011: 14) como romano-republicanos (Sousa e Arruda 2014: 59-60), tendo vindo a ser nestes contextos mais antigos designada por "grande taça carenada".

Também confundível com as tigelas, sobretudo se manusearmos pequenos fragmentos, são alguns pratos (patinae). Nos contextos desta fase, identificámos três exemplares, um da Bética costeira e os restantes do vale do Guadalquivir (fig. 21, n 13 ), classificação que somente foi possível por apresentarem perfis ou características próprias. É uma forma utilizada quer nos serviços de mesa, quer nos de cozinha, apresentando perfis 


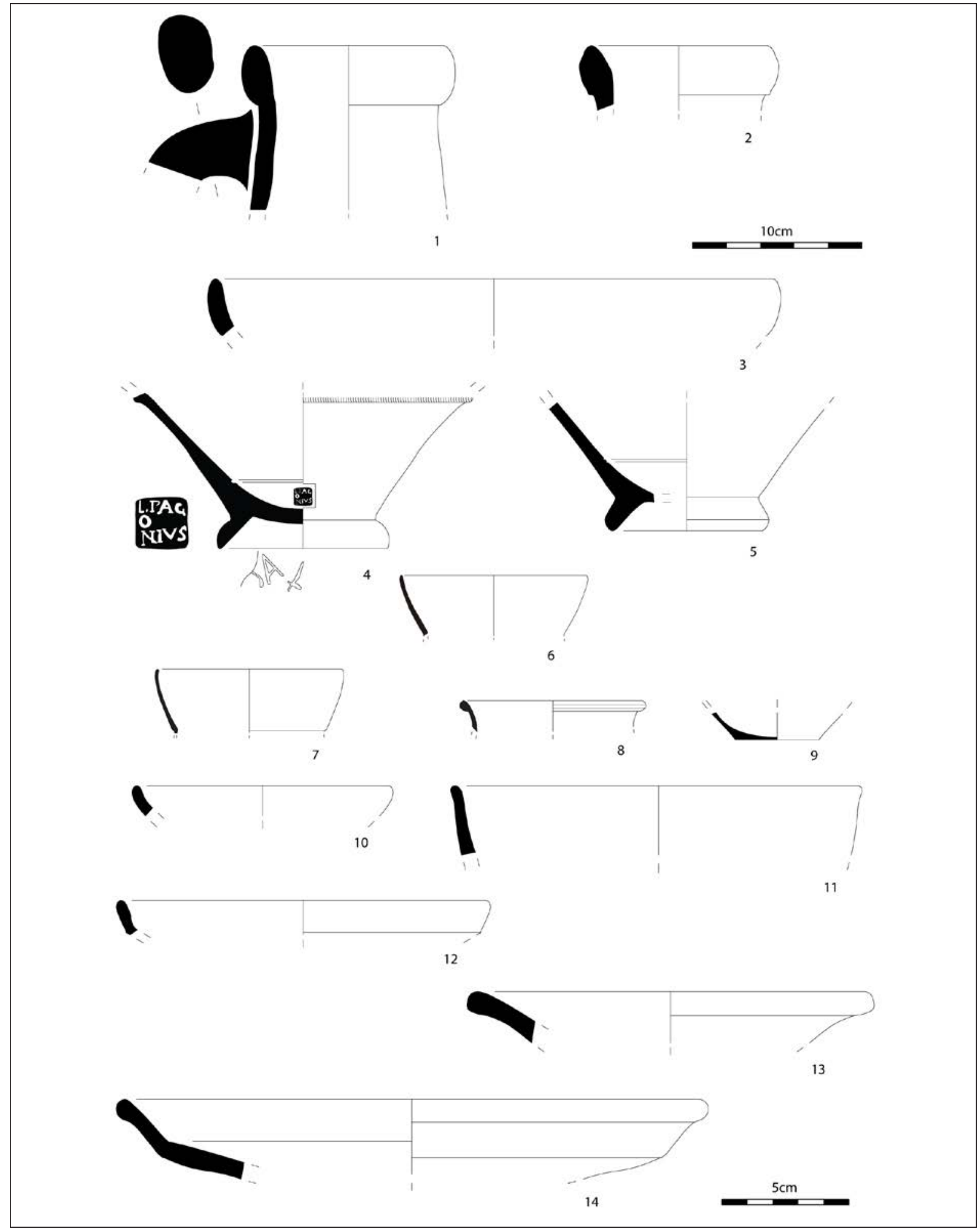

Figura 19. Materiais da Fase IV da cisterna de Monte Molião. № 1 e 2 - Ânforas; № 3 e 5 - Terra Sigillata itálica; No 4 - Terra Sigillata sudgálica de "tipo itálico"; No 6 a 9 - Cerâmica de Paredes Finas; № 10 - Cerâmica campaniense itálica napolitana; $\mathrm{N}^{\mathrm{o}} 11$ e 12 - Cerâmica campaniense itálica calena; $\mathrm{N}^{\mathrm{o}} 13$ e 14 - Cerâmica campaniense de pastas cinzentas. 
simples baixos, fundo plano e largo, e bordos aplanados frequentemente com amplos diâmetros. Alguns exemplares de produção local/regional ostentam indícios de exposição ao fogo, o que sugere que também foram utilizados como sertãs. Essa função foi indiscutivelmente desempenhada por um outro fragmento, correspondente a uma pega (fig. 20, no 14), e que caberá no tipo 15.1 de Lourdes Girón (2017: 294). Estes recipientes registam-se por todo o Mediterrâneo e foram já considerados herdeiros dos pratos de engobe vermelho pompeiano (Aguarod 1991: 259-260). Aliás, os de cerâmica comum produzidos no Lácio e na Campânia (Olcese 2003: 86; Quercia 2004: 204) parecem ter convivido com aqueles, sendo mais tardios os de importação bética.

Os potes foram maioritariamente importados da Bética costeira (11 exemplares), sendo de produção local/ regional três fragmentos, tendo apenas um sido importado do vale do Guadalquivir. Daqueles, cinco podem incluir-se na categoria de ollae da tipologia de Lourdes Girón (2017: 247 e ss.), e terão sido utilizados quer na confecção quer na contentorização de alimentos, e sete na de urcei. Embora um dos potes tenha permitido apenas a sua classificação no tipo genérico, por não permitir representação gráfica, outro tem correspondência com a forma 13.6 (Girón Anguiozar 2017: 253-254) (fig. 21, $\mathrm{n}^{\mathrm{o}} 15$ ), correspondendo, neste caso, a um recipiente pintado, seguramente utilizado como pote.

Outro ainda integra a forma 13.7 (fig. 21, no 16), tratando-se de um recipiente de tendência globular, com o bordo engrossado e exvertido, geralmente com um sulco no interior que serviria para apoiar uma tampa (idem: 254). Ambos têm equivalência nos tipos 1 de Mercedes Vegas (1973:14-16) e 235 de Marie-Helène e Jacques Santrot (1979: 130), com cronologias balizáveis entre meados do século I e IV.

Outro fragmento pôde ser considerado da variante 14 (Girón Anguiozar 2017: 260) (fig. 21, n 17), também importado da Bética costeira, forma que ostenta uma morfologia similar à das "tinajas" GDR 8.1.1 da tipologia de António Sáez (2005: 158-159), podendo aquela variante ser herdeira destas. A principal diferença entre elas consiste na presença, no caso dos recipientes alto-imperiais, de um colo alto e ligeiramente oblíquo (Girón Anguiozar 2017: 260). Embora ofereça semelhanças ao nível do bordo, a peça n ${ }^{\circ}$ 18, da Fig. 21 deverá ser integrada no tipo 13.15 (idem: 261).

Como já referimos, na categoria dos urcei cabem sete fragmentos, um deles exibindo características tecno-petrográficas de difícil adscrição geográfica (fig. 22, $\mathrm{n}^{\mathrm{o}}$ 1). Embora tenhamos atribuído a estes recipientes uma função relacionada com a água, deve sublinhar-se a sua polivalência, já justificada e evidenciada pela variedade de morfologias documentadas (Girón Anguiozar 2017: 41-42). Por outro lado, aquele conceito latino engloba, tal como acontece para as ollae, recipientes que se destinaram à confecção de alimentos, à contentorização ou mesmo a ambas. Assim, entende-se melhor que o fragmento de Monte Molião, incluído na forma 18.4 (idem: 334-335), apresente evidentes vestígios de exposição ao fogo, estando a morfologia do bordo apta a apoiar uma tampa, o que também é relevante neste contexto. Além deste, outro exemplar foi incluído na mesma variante (fig. 22, $\mathrm{n}^{\mathrm{o}} 2$ ).

Os restantes cinco fragmentos classificados como urcei (fig. 22, $\mathrm{n}^{\mathrm{o}} 3$ a 5), forma 18 de Lourdes Girón (2017), não permitem grandes considerações por corresponderem aos típicos fundos de pé simples e destacado.

Os cinco jarros cabem todos na grande categoria das lagoenae (forma 11) e correspondem integralmente a importações da Bética costeira. Destes, apenas três permitiram integração nas variantes desse tipo: um integra-se na forma 11.18 (Girón Anguiozar 2017: 218) (fig. 22, no 6); os outros têm equivalência aos tipos 11.34 de Lourdes Girón (fig. 22, n 7 ) e 348 de Marie-Helène e Jacques Santrot (1979: 162). São jarros de perfil piriforme, bordos exvertidos aplanados ou engrossados externamente, com cronologias compreendidas nos séculos I e II.

Entre o conjunto de cerâmica comum foram reconhecidos elementos de gutti, concretamente quatro bicos doseadores, correspondentes a bules importados do litoral gaditano. São recipientes globulares, de fundo simples, colo alto e estreito provido de filtro na base, bordos exvertidos, vincados e moldurados. Esta morfologia (Girón Anguiozar 2017: 191-194) encontra equivalência nas lagoenae e nos urcei, diferenciando-se deles apenas por ostentar o filtro no interior do colo e por possuir um bico doseador no corpo, no lado oposto à asa.

A interpretação funcional deste recipiente não está isenta de polémica, pois alguns autores consideram-nos bules destinados ao serviço do vinho, relação estabelecida através de referências de fontes clássicas (Varrão, De Lingua Latina 5: 124; Girón Anguiozar 2017: 30-31) e/ou da água (Ibidem: 191), enquanto outros admitem o seu uso para servir azeite (Hilgers 1969: 192). Por outro lado, foi sugerido que poderia corresponder a um "recipiente de sucção", atribuindo-se-lhe a denominação de biberão (Ibidem). Outros autores ainda afirmaram que a presença massiva deste tipo de vaso nas fábricas de salga da costa mauritana a partir do século I 


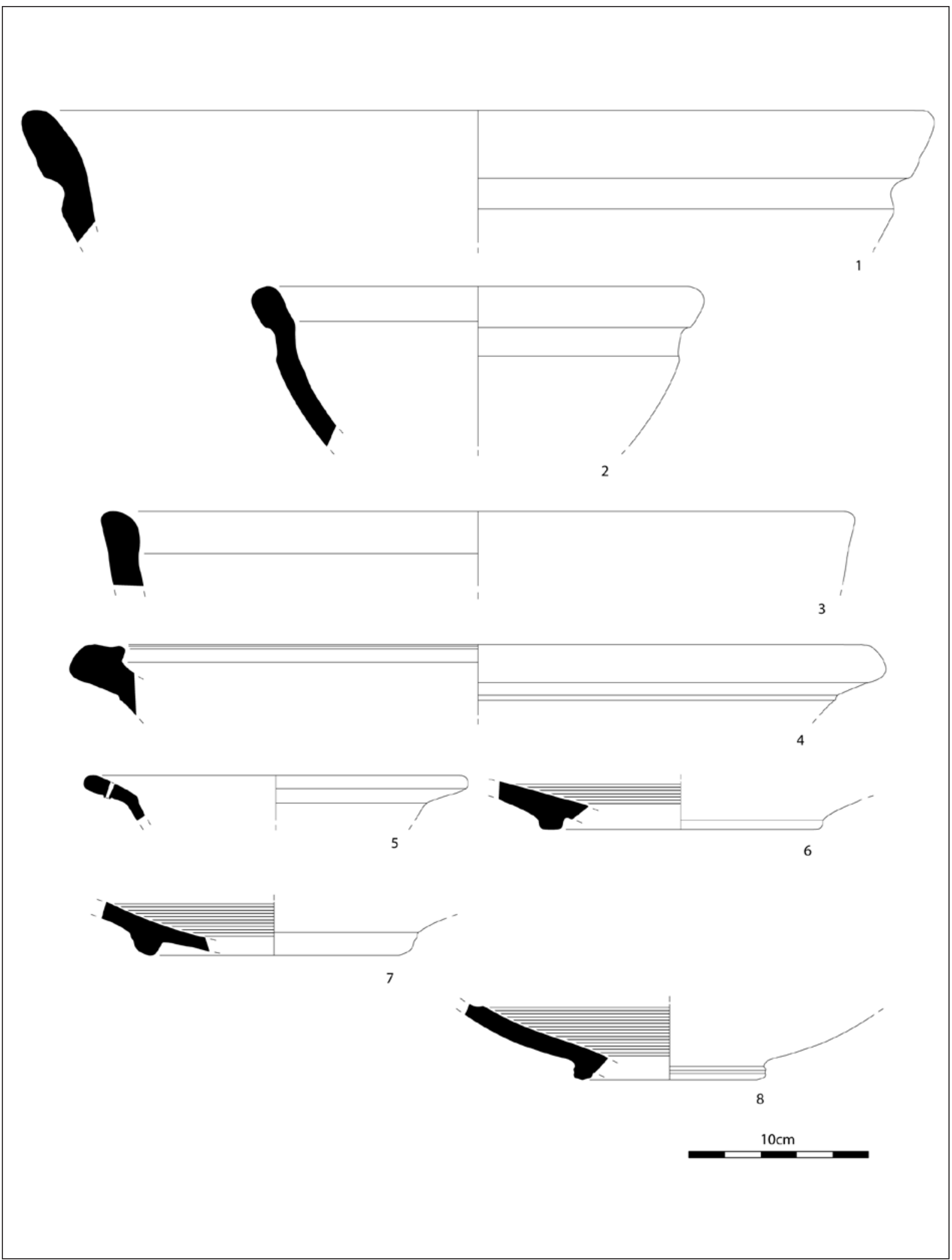

Figura 20. Materiais da Fase IV da cisterna de Monte Molião. Cerâmica Comum. 
a.n.e. indicaria que o mesmo se destinava a conter o liquamen (Ponsich e Tarradel 1965: 108-110), o que poderia explicar a presença de coador no colo.

Infelizmente, não é fácil estabelecer a origem para este tipo de peças, reconhecendo-se antecedentes de origem fenícia (Olcese 2012: 546, Tav. 2) e helenística (Morel 1965: 218). Por outro lado, e embora a cerâmica comum seja, geralmente, a categoria que reproduz as cerâmicas finas, parece sensato, neste caso, supor que a mesma forma produzida em terra sigillata Clara A (Hayes 1972: 177-178) ou em cerâmica de paredes finas (Mayet 1975: 112-113) se inspirasse nos protótipos de cerâmica comum (Sánchez 1992: 59).

As bilhas estão representadas somente por três exemplares importados, dois do litoral gaditano e um do Guadalquivir. Apesar desta classificação (Pinto e Morais 2005: 243), a maioria das tipologias incluem este tipo de recipientes na grande série de lagoenae (Girón Anguiozar 2017: 198 e ss.; Vázquez Paz et al. 2018: 139), motivo pelo qual as variantes com as quais estabelecemos paralelo correspondem ao tipo 11 da tipologia de Lourdes Girón (2017: 196 e ss.).

Apenas os fragmentos da Bética costeira permitiram classificação, concretamente nos tipos 11.6 (fig. 22, n 8) e 11.12 (fig. 22, n 9) daquela autora (idem: 204 e 211). Trata-se de variantes coevas que foram fabricadas nessa área geográfica, realidade comprovada através da descoberta de exemplares com defeitos de cozedura em Puente Melchor e em El Gallinero (Girón Anguiozar 2017: 205). Naquele sítio, estes recipientes foram datados entre a mudança da Era e o final do século IV (Lavado Florido 2004; Girón Anguiozar 2010), sendo aceitável que os exemplares recolhidos na cisterna do Monte Molião sejam dos mais antigos, sobretudo se tivermos em consideração a cronologia das restantes categorias cerâmicas recuperadas nos mesmo níveis.

Na grande categoria dos operculi cabe um total de 11 peças, correspondendo cinco a tampas comuns (duas de produção itálica e três béticas costeiras) e os restantes aos típicos opérculos de ânfora (cinco da Bética costeira e um do vale do Guadalquivir). Os opérculos distribuem-se pelos tipos 14.3 (fig. 22, $n^{\circ} 10$ a 12), 14.5 (fig. 22, $n^{\circ}$ 13) e 14.15.c (fig. 22, $\mathrm{n}^{\mathrm{o}}$ 14) da tipologia de Lourdes Girón (2017: 279 e ss.), com equivalência nos tipos 3 e 4 da tipologia de Darío Bernal e Antonio Sáez (2008).

As tampas comuns foram consideradas similares aos tipos 14.11 (fig. 22, no 15) e 14.12 (fig. 22, no 16 e 17) da tipologia mais recente (Girón Aguiozar 2017: 285-287). Estas podem, contudo, ter sido utilizadas com outras finalidades que não a de tampa, já que a sua morfologia é igualmente apta para servir como prato ou tigela.
Dois exemplares correspondem a importações itálicas (fig. 22, no 18 e 19) e ostentam no bordo claros indícios de exposição ao fogo, característica aliás também visível nos exemplares gaditanos. Embora pouco frequentes, os artefactos com aquela origem foram importados desde época romana-republicana para o Monte Molião, sendo depois substituídos pelos produzidos na Baía de Cádis (Sousa e Arruda 2014: 62, fig. 4). Estes fragmentos de importação itálica integram a forma 6 de Aguarod (1991: 118-119) e fariam conjunto com os urcei da forma Celsa 79.28 (ibidem: 101). A sua importação terá findado durante a primeira metade do século I, correspondendo estes exemplares a uma dessas últimas importações.

Os contextos desta fase do enchimento da cisterna contemplam ainda outros artefactos, que são pouco expressivos e deverão corresponder a materiais residuais, como é o caso de um exemplar de cerâmica de tipo Kuass, concretamente da forma IX de Niveau (2003).

Dos 31 artefactos metálicos recolhidos, a grande maioria (19) corresponde a pregos. Porém, foram ainda reconhecidos três rebites e uma placa metálica, que podem ter correspondido a algum tipo de aplique. Merece ainda destaque a presença de um espigão de fíbula. Trata-se de uma peça de tipo "Aucissa", para a qual vem sendo aceite uma datação balizada entre os reinados de Augusto e o de Cláudio (Erice Lacabe 1995: 127-128), cronologia corroborada pelos abundantes exemplares do território actualmente português, recolhidos no trabalho de Salete da Ponte (2006: 355-360).

\subsection{Fase V: derrube parcial da estrutura}

O número de artefactos recolhidos no que designámos Fase V é escasso (22), talvez porque à mesma se associou uma única unidade estratigráfica. Da mesma provêm três ânforas, dez fragmentos de cerâmica comum, dois de terra sigillata itálica e quatro metálicos, estando as cerâmicas de paredes finas, a terra sigillata hispânica e a campaniense representadas por um fragmento cada.

Atendendo à pouca expressividade do conjunto e ao facto de a maioria dos materiais ser inclassificável, destacamos somente aqueles que permitem tecer algumas considerações crono-estratigráficas sobre a estrutura hidráulica. Assim, para os dois exemplares de ânforas de tipo Haltern 70 (um bordo e uma asa) do Guadalquivir, não ilustráveis, são válidas as considerações tecidas para as da fase antecedente.

Os dois exemplares de terra sigillata itálica parecem estar em conformidade com os dados anfóricos. 


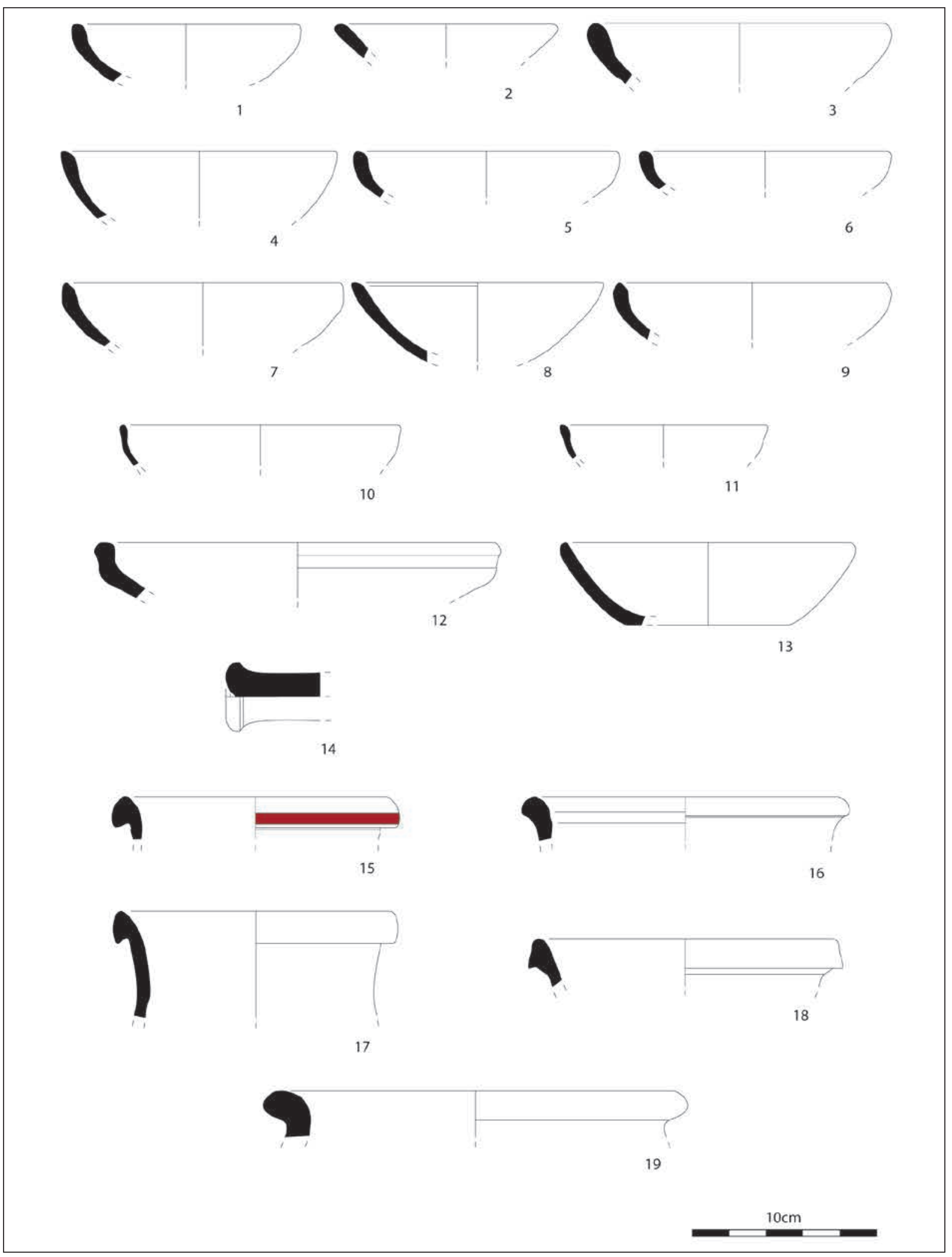

Figura 21. Materiais da Fase IV da cisterna de Monte Molião. Cerâmica comum e pintada. 
Um deles integra-se na forma Consp. 4.6.1 e data-se em meados do século I (Arruda e Dias 2018), sendo o restante inclassificável, tal como acontece com o de terra sigillata hispânica.

Para o fundo de cerâmica de paredes finas, já estudado (Sousa e Arruda 2018: fig. 5, n 48), propôs-se a sua integração na forma Mayet VIII, uma vez que partilha com os análogos dos contextos mais antigos do enchimento da cisterna as mesmas características morfo-petrográficas.

Merece ainda destaque o conjunto de cerâmicas comuns e pintadas (10 fragmentos), dos quais a maioria é proveniente da Bética costeira, com excepção de um único, com pasta que permite considerá-lo uma produção do vale do Guadalquivir. A primeira destas peças parece corresponder a uma bilha, de bordo triangular e colo estreito, conservando ainda o arranque da asa (fig. 23, $\mathrm{n}^{\circ}$ 1). Apesar de se tratar de uma produção da Bética litoral e de ter sido já identificada por outros autores (Pinto e Morais 2005: 243, fig. 16, $\mathrm{n}^{\mathrm{o}}$ 146), a forma não está contemplada na tipologia de Lourdes Girón, parecendo estar incluída na grande categoria das lagoenae. Este recipiente em concreto também não aparece no repertório da cerâmica comum dos contextos do Patio de Banderas em Sevilha, apresentando, contudo, algumas semelhanças com as bilhas da fácies II Imperial (Vázquez Paz et al. 2018: 139, fig. 6).

Um outro fragmento integra esta última categoria, concretamente a forma 11.14.a (fig. $23, \mathrm{n}^{\circ} 2$ ), representando uma variante que ainda não tinha sido identificada nos contextos mais antigos do enchimento da estrutura hidráulica. Trata-se de uma forma globular, de colo estreito e bordo exvertido e engrossado. O fragmento conserva ainda o arranque da asa. Lourdes Girón propõe para a forma uma cronologia alto-imperial (Girón Aguiozar 2017: 214).

Os urcei continuam a aparecer nestes contextos (fig. 23, $\mathrm{n}^{\mathrm{o}} 3$ ), concretamente os da forma 18.1 (Girón Aguiozar 2017: 331), o que, tendo igualmente em consideração os restantes materiais, pode significar que esta fase não é temporalmente distante da precedente.

O único fragmento de cerâmica campaniense de pasta cinzenta identificado, que não permitiu classificação, corresponderá a material residual.

\subsection{Fase VI: amortização e entulhamento da cisterna}

Os contextos atribuídos à Fase VI englobam potentes estratos com abundantes restos arquitectónicos, argamassas de revestimento e de pavimentos e frequentes pedras de dimensões consideráveis. Estas realidades comprovam que se trata de um entulhamento premeditado, que selou definitivamente a estrutura. A quantidade de materiais recolhida é apreciável (248 artefactos), sendo os mesmos diversificados, quer cronologicamente quer do ponto de vista das categorias identificadas.

A variabilidade cronológica resultará do facto de a cisterna ter sido entulhada com sedimentos e restos arquitectónicos anteriores ao momento desta amortização, mas também contemporâneos da mesma, como é o caso de fragmentos de opus tessellatum.

Uma vez que a maioria do conjunto de materiais se encontra em contexto secundário, não sendo relevante para a discussão da datação desta fase, algumas categorias e formas concretas são apenas mencionadas, dando-se em contrapartida especial destaque àquelas que seriam coevas da referida amortização.

Entre as ânforas, conta-se a presença de exemplares itálicos do tipo Dressel 1, do tipo Mañá $\mathrm{C} 2$, gaditanos e africanos, do tipo Castro Marim 1, do Baixo Guadalquivir, bem como de um fragmento de um contentor de tipo Carmona de produção gaditana, todos republicanos, e um de tipo Haltern 70, produzido no vale do Guadalquivir.

Um fragmento de lucerna pode dar um relevante contributo para a datação do momento em que se selou a cisterna. Integra-se no tipo Andújar (Pereira e Arruda 2016: 168, fig. $17, \mathrm{n}^{\circ} 1$ ), preponderante durante a primeira metade do século I, ainda que o final da sua produção possa alcançar a época flávia (Sotomayor et al. 1976: 135).

Os três fragmentos de terra sigillata itálica (Arruda e Dias 2018) parecem estar em conformidade com as considerações efectuadas para a lucerna. Um deles não permitiu classificação, mas os restantes integram a forma Consp. 4, para a qual foi sugerida uma datação tiberiana (Viegas 2011: 132), embora em Monte Molião possa alcançar a segunda metade do século I (Arruda e Dias 2018).

A terra sigillata hispânica precoce está representada por três fragmentos (fig. $23, n^{0} 4$ ), dos quais somente dois permitiram classificação, nos tipos I e III de Martínez (1989). Ainda que esta categoria tenha começado a importar-se durante a primeira metade do século I para os sítios algarvios, foi já sublinhado que subsiste durante a segunda metade desse mesmo século (Viegas 2011: 320).

Os dois fragmentos de terra sigillata sudgálica são inclassificáveis, não permitindo, portanto, 


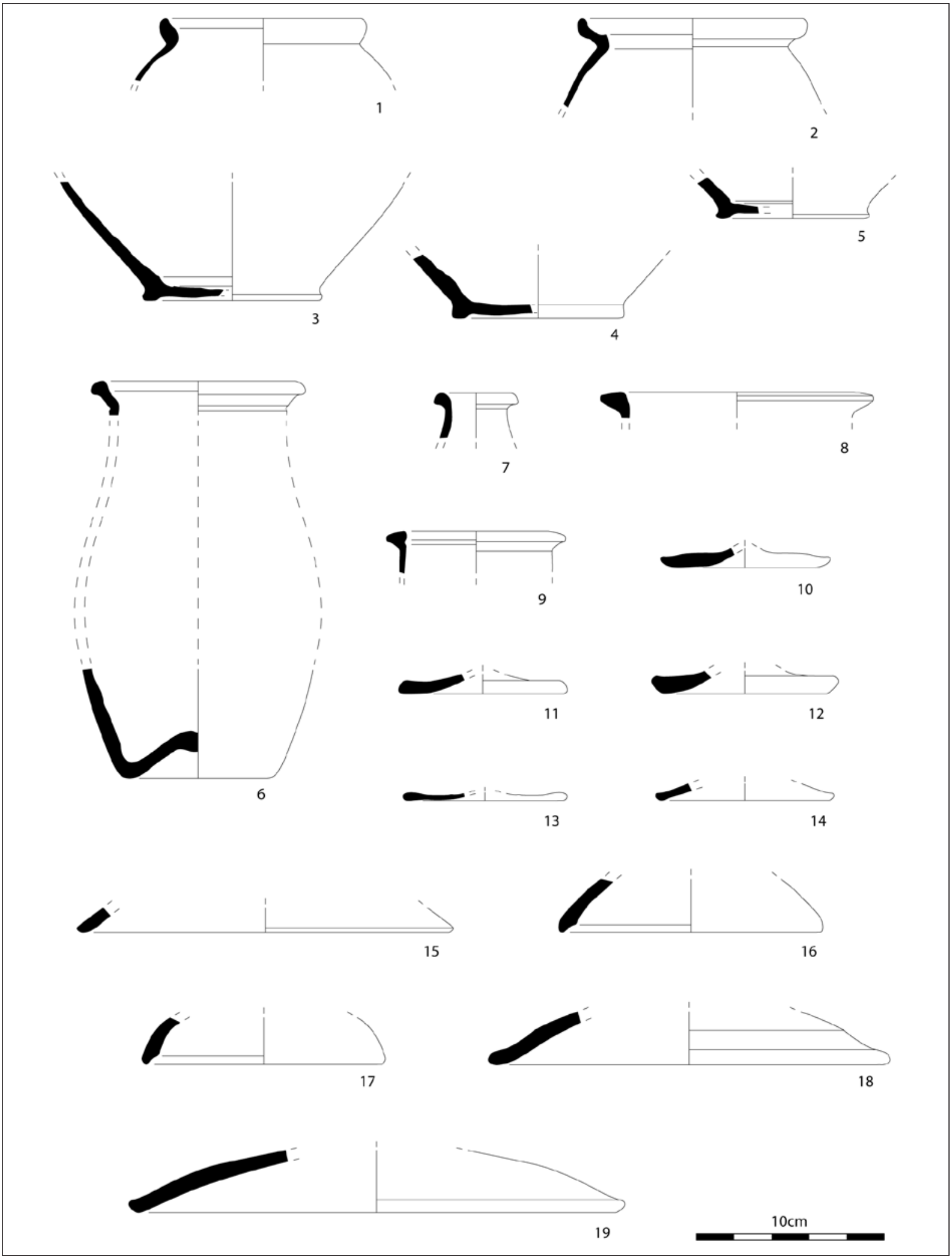

Figura 22. Materiais da Fase IV da cisterna de Monte Molião. Cerâmica Comum. 
considerações de ordem cronológica, mas a sua abundância em contextos do Monte Molião durante a segunda metade do século I deve ser tida em consideração.

As restantes cerâmicas finas oferecem cronologias consideravelmente mais antigas quando comparadas com as que considerámos contextualmente seguras. É o caso da cerâmica campaniense (sete fragmentos), distribuída pelas produções napolitanas, calenas e de imitações de pasta cinzenta (fig. 23, n 5 a 7), da de tipo Kuass (oito fragmentos), ou da de paredes finas (três fragmentos), da qual se identificou um bordo do tipo Mayet II e um fragmento do tipo VIII, que conserva ainda o colo da peça e ostentando uma máscara aplicada (fig. 24). Além destes, identificou-se ainda um fragmento de cerâmica ática de verniz negro.

Algumas formas de cerâmica comum são antigas, como é o caso dos pratos de bordo em aba pendente ou das "tinajas", mas outras podem entender-se enquanto continuidade das importações ou imitações das produções béticas. Este parece ser o caso dos urcei (fig. 23, $\mathrm{n}^{\mathrm{o}}$ 8 e 9) e de alguns jarros (fig. $23, n^{\circ} 10$ a 12).

Os dados obtidos através da análise do conjunto cerâmico contemporâneo da formação destes estratos permitem propor que o entulhamento definitivo da cisterna terá ocorrido em momento indeterminado da segunda metade do século I.

\subsection{Fase VII: uma fossa de despejos do Baixo Império}

Englobamos na Fase VII um contexto muito particular documentado junto à cabeceira Norte da estrutura e já anteriormente estudado (Arruda e Gomes 2013). Os estratos correspondentes à colmatação intencional da cisterna (Fase VI) foram cortados nessa zona pela abertura de uma fossa destinada ao despejo de entulhos.

No interior desta interface negativa identificaram-se dois níveis de enchimento, muito similares entre si, formados por areias soltas, cinzas e/ou cal, que incorporavam uma grande quantidade de material de construção, nomeadamente tegulae, imbrices, tijolos de quadrante e restos de reboco com pintura vermelha escura (idem: 154).

O conjunto artefactual que acompanhava estes elementos construtivos era relativamente reduzido e díspar, compondo-se fundamentalmente de espólios que podem considerar-se residuais. Os materiais que podem, em contrapartida, associar-se de forma directa a este episódio de uso oportunista da cisterna como entulheira são escassos, mas ainda assim significativos.
O conjunto de materiais primários desta fase inclui um prato de terra sigillata Clara C, da forma Hayes 50B, três páteras de terra sigillata Clara $\mathrm{D}$, da forma Hayes 58B, uma ânfora lusitana de tipo Almagro 51C, produzida nos ateliers do Tejo/Sado, e restos de bojo de uma ânfora Africana Grande da Tripolitânia (idem: 151-154).

Considerado globalmente, este conjunto de materiais cerâmicos permitiu datar este episódio de reutilização da antiga cisterna de um momento impreciso da segunda metade do século IV (idem: 155), cronologia que podemos agora afinar graças ao estudo do conjunto numismático (v. infra), situando este contexto no final daquela centúria, ou mesmo mais provavelmente no início do século V. Este horizonte corresponde, portanto, a um período em que o povoado se encontrava já abandonado. A dinâmica que resultou na formação deste contexto é por isso difícil de restituir e de enquadrar, parecendo de momento um epifenómeno isolado na história da ocupação do Monte Molião.

\subsection{Os numismas da cisterna do Monte Molião}

A escavação dos sedimentos de enchimento da cisterna de Monte Molião permitiu também a recolha de um conjunto de numismas que totaliza 11 exemplares. Infelizmente, a maioria é proveniente dos estratos revolvidos resultantes da "escavação" da estrutura no final do século XIX. Assim, apenas seis foram recolhidos claramente em contexto, três nos estratos da Fase IV e três nos da Fase VII.

Deve sublinhar-se que todos correspondem a perdas individuais, distribuindo-se por quatro ases, dois semis, um antoniano, dois quadrantes, um meio centenional e outro correspondente a uma fracção de centenional.

Deste conjunto, cinco oferecem cronologias anteriores à viragem da Era, concretamente um as, dois semis e dois quadrantes. Destes, merece destaque o correspondente a um as partido de OSSET (fig. 25), datado do século I a.n.e., recolhido em estratos da Fase IV, e que ostenta uma figura segurando um cacho de uvas (RIC I 58; Villaronga 1994: 396), iconografia típica nas cunhagens desta ceca. Esta moeda foi claramente partida de forma intencional para se poder converter em dois semis, situação que foi frequente entre os séculos II e I a.n.e., devido à escassez de numerário circulante.

Os restantes numismas que ofereceram datações romano-republicanas correspondem a cunhagens algarvias, duas de Cilpes e duas, eventualmente, de Ossonoba. Os primeiros foram produzidos em bronze, ostentando o típico atum virado para a direita, possuindo um peso que varia entre 3 e $6 g$. Os 


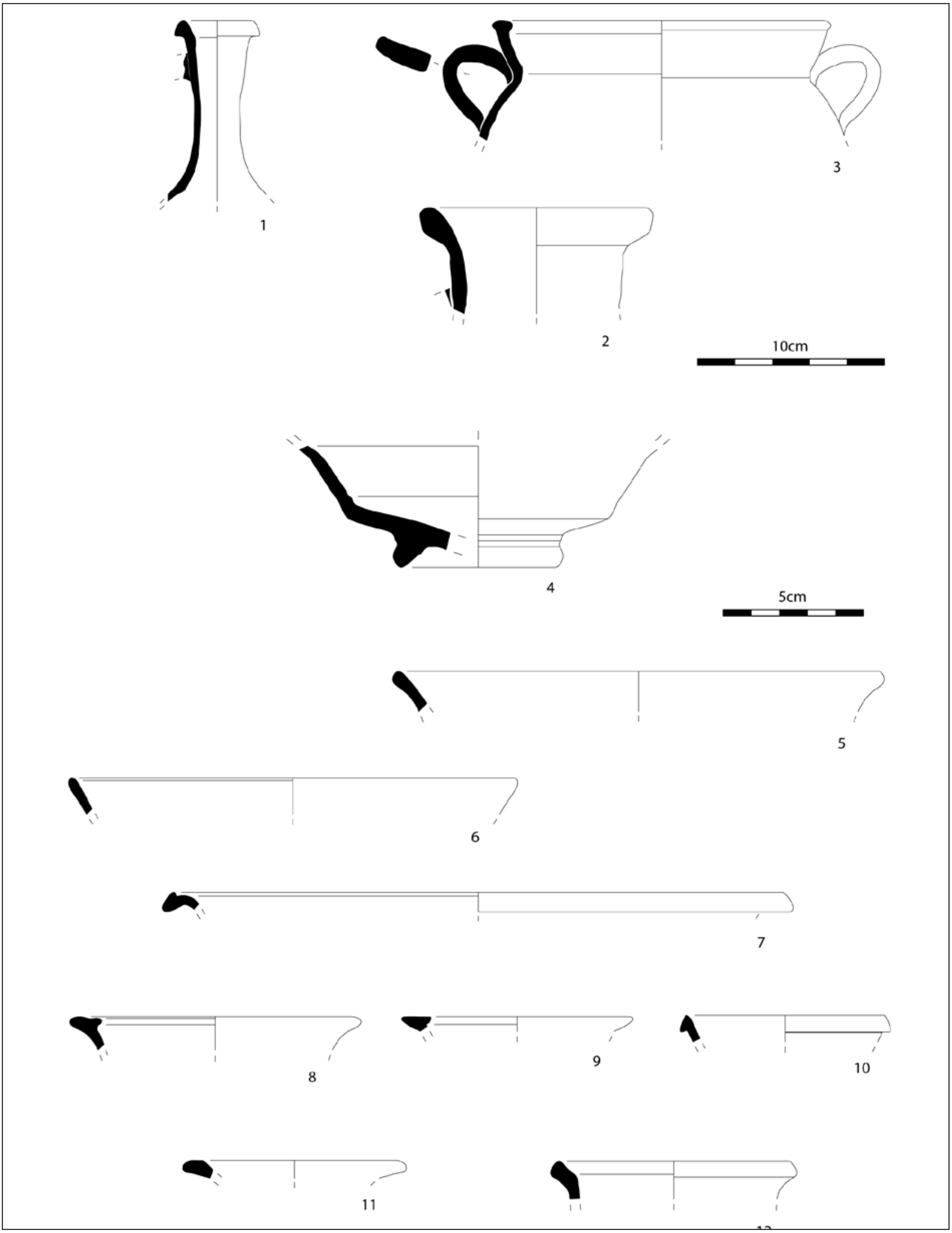

Figura 23. Materiais da Fase V da cisterna de Monte Molião. $N^{\circ} 1$ a 3 - Cerâmica comum. Materiais da Fase VI. No 4 - Terra Sigillata hispânica; $\mathrm{N}^{\mathrm{o}} 5$ a 7 - Cerâmica campaniense; $\mathrm{N}^{\mathrm{o}} 8$ a 12 - Cerâmica comum. 


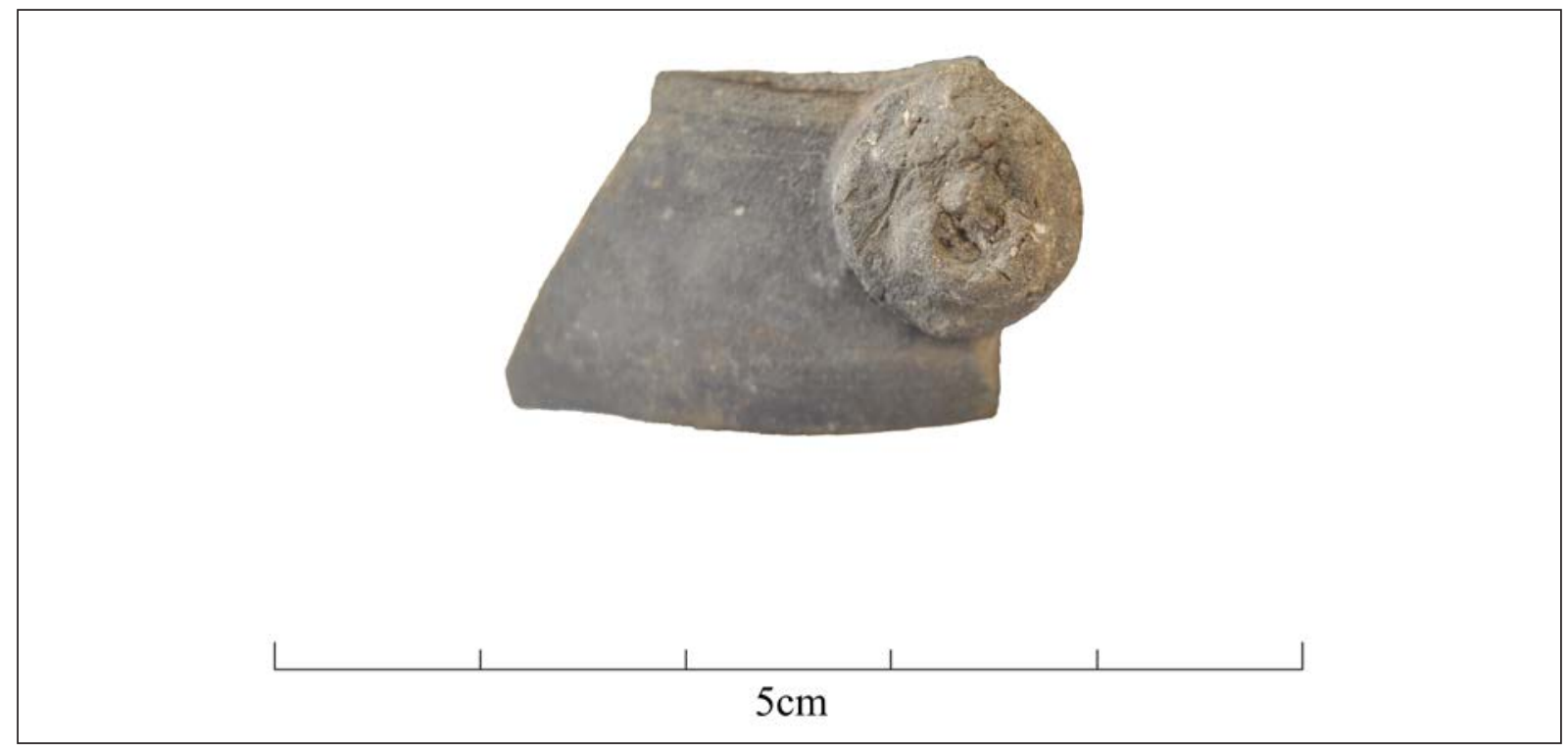

Figura 24. Fragmento de Paredes Finas do tipo Mayet VIII, que conserva uma máscara aplicada.

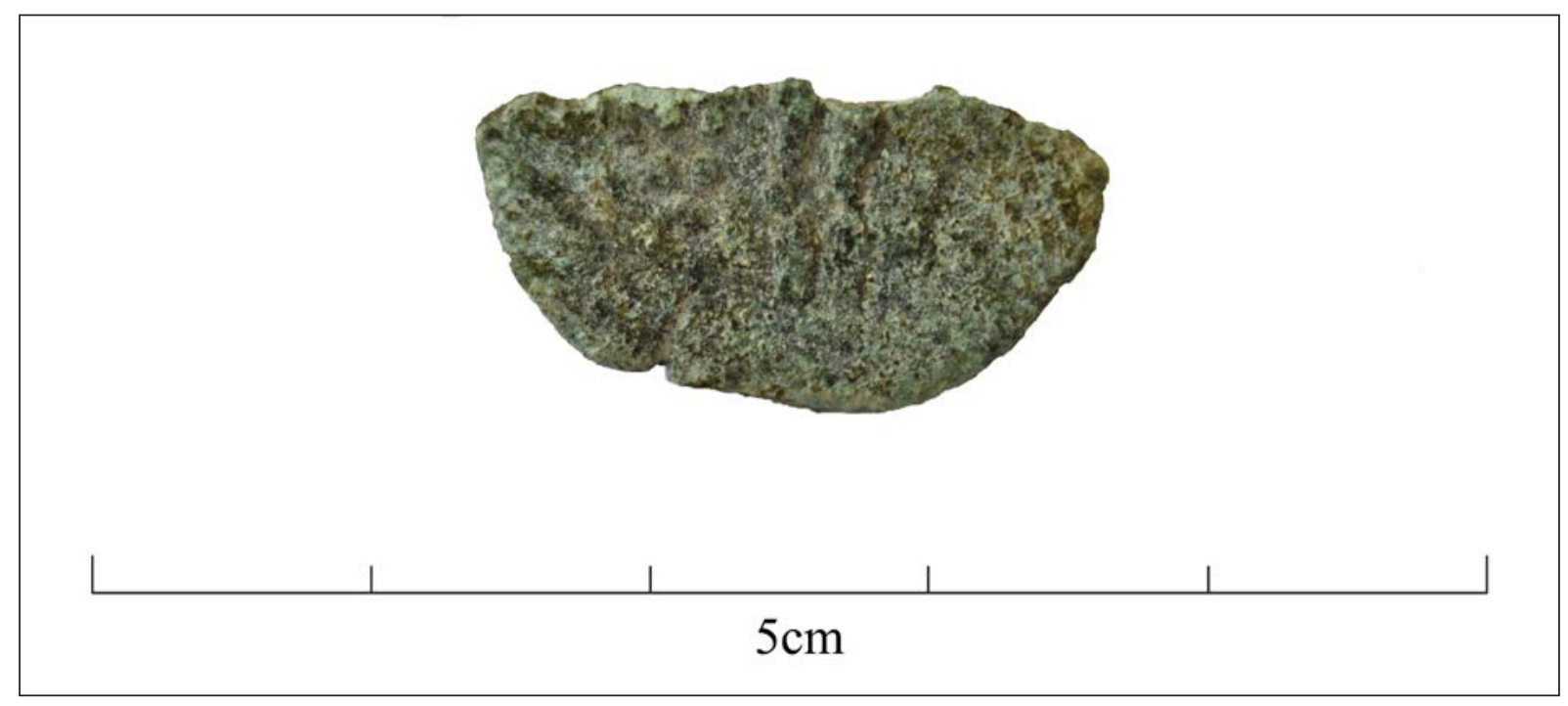

Figura 25. As partido de OSSET, datado do século I a.C. (RIC I 58).

de Ossonoba são de chumbo, exibindo também a presença de um atum, mas virado para a esquerda, com um peso que varia entre 2,3 e 2,9g. Destes numismas, apenas dois foram recuperados em estratos da Fase IV da cisterna, sendo os restantes provenientes de unidades revolvidas.

Ainda que igualmente descontextualizado, outro numisma oferece uma datação coetânea com os níveis de enchimento (fig. 26). Trata-se de um as augustano, cunhado em 7 em Roma por P. Lurius Agrippa (RIC I 427; Sutherland, 1984), apresentando o busto de
Augusto no anverso, voltado para a direita, contendo, no reverso, a inscrição de Agripa.

Nos estratos da fase mais tardia, a VII, foram recolhidos três numismas de bronze, concretamente dois ases e um antoniniano. Os ases foram ambos cunhados em Roma, sob os reinados de Calígula (RIC I 58), entre 37 e 41, e de Cláudio (RIC I 113), entre 41 e 42 . O antoniniano corresponde a uma cunhagem de Roma, do reinado de Galieno (RIC V-I 355) e, portanto, mais tardia (260-268), mas ainda assim residual posto que o contexto em questão foi já datado do século IV (Arruda e Gomes 2013: 155). 


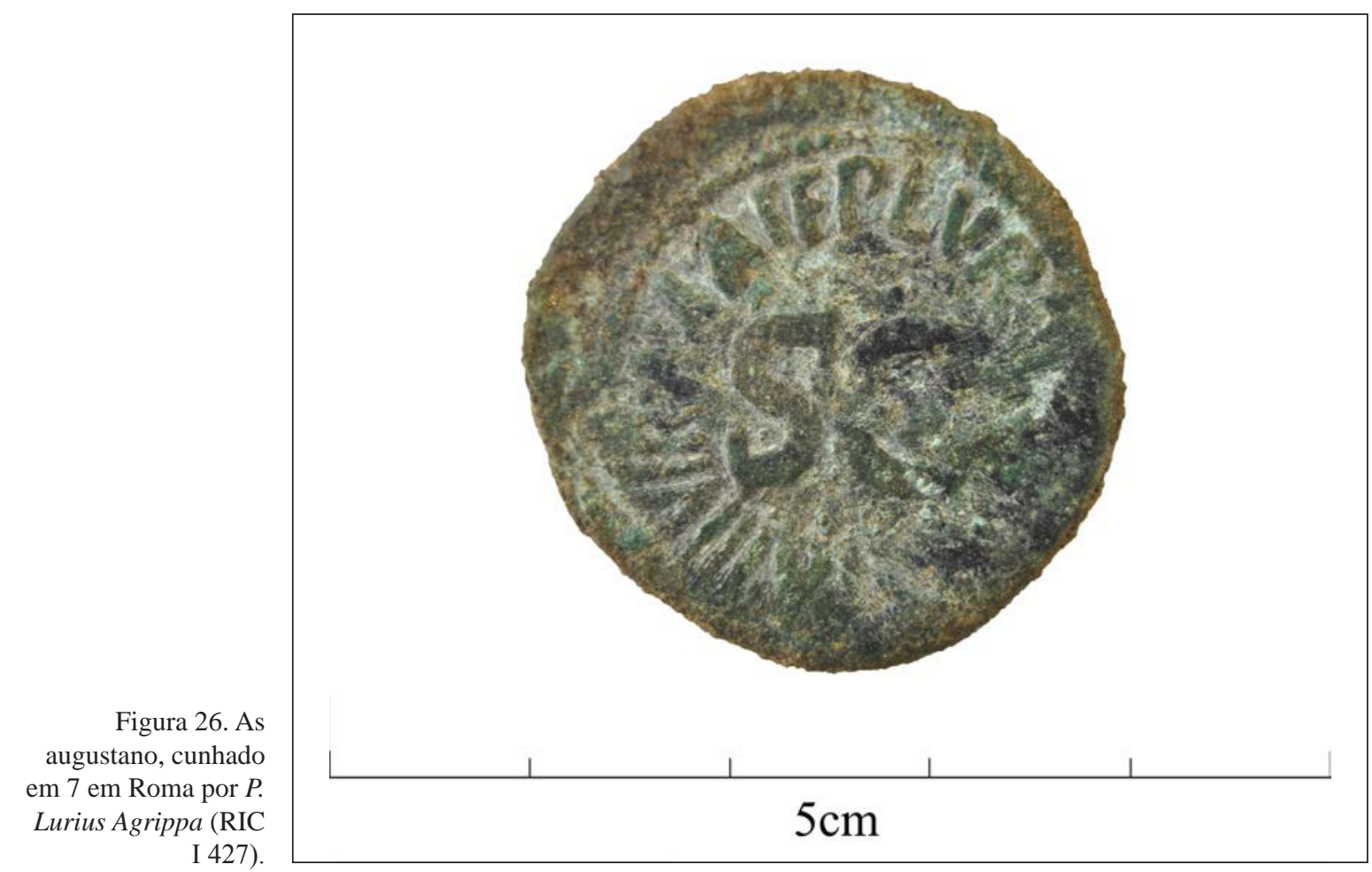

A existência de dois outros numismas, correspondentes a centenionais, obrigam igualmente a considerar uma cronologia mais tardia para a ocupação baixo-imperial da envolvente da cisterna. Um deles é um meio centenional de Honório (RIC X 149; Mattingly et al. 1923), datável de 393-395, com um peso de $1.0 \mathrm{~g}$, apresentando o busto do imperador virado para a direita, no anverso e, no reverso, Honório a cavalo, caminhando para a direita. O outro, de peso idêntico, pode considerar-se uma imitação hispânica correspondente a uma fracção de centenional de Constâncio II, cópia que terá sido realizada na segunda metade do século IV.

Embora estes numismas sejam provenientes de estratos revolvidos, correspondentes a violações recentes, remetem para um momento que pode ser considerado de finais do século IV/inícios do V, e devem, portanto, ser relacionados com a ocupação tardia no contexto da qual se geraram os níveis da Fase VII da cisterna.

\subsection{A cronologia da construção, utilização e abandono da cisterna de Monte Molião}

Alguns contextos coetâneos à estrutura hidráulica de Monte Molião foram já datados entre os principados de Augusto e de Calígula, cronologia que foi suportada pelo estudo da terra sigillata itálica recolhida no interior da cisterna (Arruda e Dias 2018). O trabalho que concretizámos sobre a totalidade do espólio recuperado permitiu ir mais além na definição desta proposta, que tem também em consideração a sequência estratigráfica e a respectiva leitura relativa, e alguns detalhes construtivos.

Como já atrás referimos, a construção de estruturas negativas é sempre difícil de datar, a não ser através de extrapolações elaboradas a partir de dados referentes à sua utilização. Neste caso concreto, o facto de termos comprovado a existência de uma reparação do fundo da cisterna em época republicana, reparação que designámos como Fase II, permite admitir que esta estrutura foi edificada ou durante a Idade do Ferro, que em Monte Molião está datada entre o século IV e o final do século III a.n.e., ou então já em época romana republicana, no século II a.n.e. Tendo em consideração os paralelos aduzidos no ponto 2, parece que a segunda cronologia será mais adequada para a construção desta estrutura, que foi reparada, muito possivelmente, ainda antes da viragem da Era.

Os materiais da Fase III, acima estudados detalhadamente, evidenciam a utilização intensiva da cisterna durante o final do século I a.n.e., uso que pode ter-se prolongado nas primeiras décadas do seguinte. 
Quadro 1. Distribuição das fases atribuídas à cisterna de Monte Molião, cronologias.

\begin{tabular}{|c|c|c|c|c|}
\hline & Interpretação & Cronologia & $\begin{array}{c}\mathrm{N}^{0} \text { total de } \\
\text { artefactos } \\
(\mathrm{nmi})\end{array}$ & Categorias e formas representativas \\
\hline Fase I & Construção do reservatório & - & - & - \\
\hline Fase II & Repavimentação da base & Época romana-republicana & $\begin{array}{c}\text { Inertes } \\
\text { com pastas } \\
\text { itálicas }\end{array}$ & - \\
\hline Fase III & $\begin{array}{l}\text { Última utilização da cis- } \\
\text { terna }\end{array}$ & $\begin{array}{l}\text { Final do séc. I e } 1^{\circ} \text { decénios } \\
\text { do seguinte }\end{array}$ & 56 & $\begin{array}{l}\text { - Ânforas (Haltern 70); } \\
\text { - Paredes Finas (Mayet II, III e VIII); } \\
\text { - Cerâmica comum; } \\
\text { - Lucerna; } \\
\text { - Unguentário; }\end{array}$ \\
\hline Fase IV & $\begin{array}{l}\text { Utilização pontual como li- } \\
\text { xeira }\end{array}$ & $\begin{array}{l}\text { Segundo quartel do séc. I } \\
\text { d.C. }\end{array}$ & 226 & $\begin{array}{l}\text { - Ânforas (Haltern 70; Classe 67; } \\
\text { Ovóide 6; Dressel 7/11); } \\
\text { - Terra sigillata (itálica consp. } 4 \text { e } \\
\text { 23.2; sudgálica de”tipo itálico" } \\
\text { consp. 22; hispânica precoce); } \\
\text { - Paredes Finas (Mayet VIII, Mara- } \\
\text { bini XXXI); } \\
\text { - Campaniense de pasta cinzenta; } \\
\text { - Cerâmica comum; }\end{array}$ \\
\hline Fase V & Derrube parcial da estrutura & Meados do séc. I d.C. & 22 & $\begin{array}{l}\text { - Ânforas (Haltern 70); } \\
\text { - Terra sigillata (itálica consp. } \\
\quad \text { 4.6.1); } \\
\text { - Paredes Finas (Mayet VIII); } \\
\text { - Cerâmica comum; }\end{array}$ \\
\hline Fase VI & Entulhamento da cisterna & Época flávia & 248 & $\begin{array}{l}\text { - Ânforas (Haltern } 70 \text { flávia); } \\
\text { - Lucerna de "tipo Andújar"; } \\
\text { - Terra sigillata (itálica consp. 4; } \\
\text { hispânica precoce Martínez I e III; } \\
\text { sudgálica inclas.); } \\
\text { - Cerâmica comum; }\end{array}$ \\
\hline Fase VII & Fossa do Baixo Império & $\begin{array}{l}\text { Final do séc. IV/início do } \\
\text { séc. V }\end{array}$ & 138 & $\begin{array}{l}\text { - Ânforas (Almagro 51C); } \\
\text { - Terra sigillata (norte africana } \\
\text { Clara D). }\end{array}$ \\
\hline
\end{tabular}

O abandono desta estrutura terá tido lugar ainda durante a primeira metade do século I, como os espólios recolhidos nos estratos da Fase IV, fase em que serviu como lixeira, claramente documentam. O seu derrube parcial terá acontecido em meados deste mesmo século (Fase V), e o seu entulhamento e amortização definitiva na segunda metade daquela centúria, possivelmente em época flávia (Fase VI). O “episódio" da Fase VII está bem datado do final do século IV/início do $\mathrm{V}$.

Temos consciência que esta sequência cronológica (quadro 1) é porventura excessivamente comprimida. Mas a verdade é que os diversos estratos comprovam uma sucessão de realidades distintas, que se seguem no tempo, mas que nunca ultrapassam o século I, com excepção, naturalmente da Fase VII.

\section{A CISTERNA DO MONTE MOLIÃO NO CONTEXTO DA OCUPAÇÃO DO SÍTIO.}

O estudo que concretizámos permite ainda uma série de observações finais que parecem relevantes e importa discutir.

Em primeiro lugar, deve destacar-se o facto de a cisterna de Monte Molião corresponder ao mais ocidental exemplo de uma estrutura hídrica a bagnarola, 
realidade que pode e deve relacionar-se com as influências púnico-gaditanas que o sítio sofreu desde a sua fundação, no século IV a.n.e. (Arruda et al. 2011), e que se mantiveram ao longo de toda a sua ocupação, muito especialmente na época republicana, tendo já por diversas vezes sido valorizadas. Por outro lado, esta situação remete para a antiguidade da construção da cisterna, cuja datação pode situar-se entre os séculos IV e II a.n.e. de acordo com as sequências estratigráficas observadas e com os detalhes da construção e cronologia da primeira reparação. Certo é que esteve em utilização entre a época republicana e a $1^{\mathrm{a}}$ metade do século I.

O tipo de estrutura, as suas dimensões e capacidade remetem para o seu carácter público. Mesmo que se admita que esta cisterna não foi o único recurso do grupo no que se refere ao abastecimento de água potável, tudo indica que representou um importante papel nesse domínio, podendo defender-se que o "bairro" republicano identificado no Sector C se serviu dela, não sendo também improvável que a água que nela se ia depositando fosse transportada para o mais distante Sector A do povoado em recipientes apropriados para o efeito. As outras estruturas de armazenamento de água de época republicana que certamente existiram são de momento desconhecidas, bem como aliás as que estiveram em funcionamento a partir da $2^{\mathrm{a}}$ metade do século I e durante todo o século II. Estes reservatórios teriam de ser de consideráveis dimensões, dada a intensa ocupação do sítio nessa mesma época e sobretudo uma actividade oleira (Arruda et al. 2010) que, evidentemente, carecia de água em quantidades apreciáveis.

\section{Agradecimentos}

A escavação da cisterna de Monte Molião e a elaboração do presente estudo foram desenvolvidos no âmbito do projecto MOLA - O Monte Molião na Antiguidade III, integralmente financiado pela Câmara Municipal de Lagos através de um protocolo estabelecido com a Faculdade de Letras da Universidade de Lisboa e com a UNIARQ - Centro de Arqueologia da Universidade de Lisboa.

\section{BIBLIOGRAFIA}

Adroher Auroux, A. (2014): “Cerámica Gris Bruñida Republicana (GBR): el problema de las imitaciones en ceramología arqueológica", em R. Morais, A. Fernández e M. Sousa (eds.), As produções cerâmicas de imitação na Hispania. Monografias Ex Officina Hispana II: 281-290. Porto, Universidade do Porto.

Adroher Auroux, A.; Caballeros Cobos, A e López Marcos, A. (2001): "Excavación arqueológica de urgencia en la calle Palacio s/n (Guadix, Granada)". Anuario Arqueológico de Andalucía 1997 III: 285292.

Adroher Auroux, A.; Carreras Monfort, C.; Almeida, R. de; Fernández Fernández, A.; Molina Vidal, J. \& Viegas, C. (2016): "Registro para la cuantificación de cerámica arqueológica: estado de la cuestión y una nueva propuesta. Protocolo de Sevilla (PRCS/14)". Zephyrus LXXVIII: 87-110. https:// doi.org/10.14201/zephyrus20167887110

Aguarod Otal, C. (1991): Cerámica romana importada de cocina en la Tarraconense. Zaragoza, Institución Fernando el Católico.

Alarcão, A. (1975): “Céramiques à engobe rouge non grésé", em J. de Alarcão e R. Étienne (eds.), Fouilles de Conímbriga, VI. Céramiques diverses et verres: 51-58. Paris, Éditions De Boccard.

Alves, C.; Mataloto, R. e Soria, V. (2014): “As produções de imitação da campaniense itálica em pasta cinzenta no Sul do território actualmente português", em R. Morais, A. Fernández e M. Sousa (eds.), As produções cerâmicas de imitação na Hispânia. Monografias Ex Officina Hispana II: 165176. Porto, Universidade do Porto.

Arruda, A. e Dias, I. (2018): “A Terra Sigillata Itálica de Monte Molião, Lagos, Portugal". Portugália, Nova Série 39: 159-178. http://dx.doi. org/10.21747/09714290/port39a4

Arruda, A. e Gomes, F. B. (2013): "O monte Molião (Lagos) no Baixo Império: um epifenómeno". Conimbriga 52: 147-163. http://dx.doi. org/10.14195/1647-8657_52_5

Arruda, A.; Sousa, E.; Pereira, C. e Lourenço, P. (2011): "Monte Molião: um sítio púnico-gaditano no Algarve (Portugal)". Conimbriga 50: 5-32. http:// dx.doi.org/10.14195/1647-8657_50_1

Arruda, A. e Viegas, C. (2002): “As cerâmicas de "engobe vermelho pompeiano" da Alcáçova de Santarém". Revista Portuguesa de Arqueologia Vol. 5.1: 221-238.

Arruda, A. e Viegas, C. (2016): "As ânforas alto-imperiais de Monte Molião", em R. Járrega e P. Berni (eds.), Amphorae ex Hispania: paisajes de producción y consumo. Monografias Ex Officina Hispana III: 446-463. Tarragona, Institut Català d'Arqueologia Clàssica. 
Arruda, A.; Viegas, C. e Bargão, P. (2010): “A cerâmica comum de produção local do Monte Molião". Xelb 10: 285-304.

Baklouti, H. (2010): "Hydraulique préromaine en Tunisie antique. Diffusion des techniques de construction des citernes puniques en pays numide: à Dougga (Thugga) et à Kalaat Bezzaz", em M. Milanese, P. Ruggeri e C. Vismara (eds.), L’Africa Romana XVIII. I luoghi e le forme dei mestieri e della produzione nelle province africane: 183214. Olbia (2008) Sassari, Università degli Studi di Sassari.

Barreca, F. e Fantar, M. (1983): Prospezione archeologica al Capo Bon II. Roma, Consiglio Nazionale delle Ricerche.

Blázquez, J. Mª .; Contreras, R. e Urruela, J. J. (1984): Castulo IV. Madrid, Ministerio de Cultura.

Bejarano (2009): "Intervención arqueológica de urgencia en la Finca de Villanueva, Puerto Real (Cádiz)". Anuario Arqueológico de Andalucía 2004.I: 172-179.

Bernal Casasola, D. e Lorenzo Martínez, L. (1998): "Las excavaciones arqueológicas en el taller alfarero de La Venta del Carmen. Campañas de 1996 e 1997", em D. Bernal Casasola (ed.), Excavaciones arqueológicas en el alfar romano de la Venta del Carmen (Los Barrios, Cádiz): una aproximación a la producción anfórica en la Bahía de Algeciras en época altoimperial: 43-62. Los Barrios, Ayuntamiento de Los Barrios.

Bernal Casasola, D. e Sáez Romero, A. (2008): “Opérculos y ánforas romanas en el círculo del estrecho. Precisiones tipológicas, cronológicas y funcionales", em Rei Cretariae Romanae Favtorvm Acta 40, XXV Congress: 1-18. Durres (2006), Bonn, Rei Cretariae Romanae Fautores.

Berni, P. (2011): “Tipología de la Haltern 70 bética", em C. Carreras, R. Morais e E. González Fernández (coords.), Ánforas Romanas de Lugo: comercio romano en el Finis Terrae: 80-107. Lugo, Concello de Lugo.

Berrocal Rangel, L. e Ruiz Triviño, C. (2003): El depósito alto-imperial del Castrejón de Capote (Higuera la Real, Badajoz). Mérida, Editora Regional de Extremadura.

Bonetto, J.; Cespa, S. e Erdas, R. V. (2012): “Approvviogionamento idrico a Nora: nuovi dati sulle cisterne", em M. Cocco, A. Gavini e A. Ibba (eds.), L'Africa Romana XIX. Trasformazione dei paesaggi del potere nell'Africa settentrionale fino alla fine del mondo antico, 2591-2624. Sassari (2010), Sassari, Università degli Studi di Sassari.
Brancoli, I.; Ciasca, A.; Garbini, G.; Pugliese, B.; Tusa, V. e Cutroni, A. (1967): Mozia III. Rapporto preliminare della missione archeologica della Soprintendenza alle Antichitè della Sicilia Occidentale e dell’Universita di Roma. Roma, Istituto di Studi del Vicino Oriente.

Bultruni, G.; Mezzolani, A. e Morigi, A. (1996): “Approvvigionamento idrico a Tharros: le cisterne". Rivista di Studi Fenici 24: 123-127.

Burés Vilaseca, L. (1998): Les estructures hidràuliques a la ciutat antiga: l'exemple d'Empúries. Barcelona, Museu d'Arqueologia de Catalunya.

Caeiro, J. (1978): “Observações sobre a cerâmica comum romana do séc. III proveniente da "Cidade das Rosas", Serpa", em Actas das III Jornadas Arqueológicas da Associação dos Arqueólogos Portugueses Vol. 1: 249-271. Lisboa (1977), Lisboa, Associação dos Arqueólogos Portugueses.

Carvalho, P. (1998): O forum de Aeminium. Lisboa, Instituto Português de Museus.

Castellani, V. e Mantellini, S. (2001): "Le cisterne come elemento di indagine per la storia del territorio: il caso di Pantelleria”. Opera Ipogea III, 1: 5-14.

Castro García, M. ${ }^{a}$ del M. (2016): La gestión del agua en época romana: casuística en las ciudades de la provincia Hispania Ulterior-Baetica. Tese de Doutoramento em História, Université Laval/Universidad de Cádiz. Inédita.

Castro García, M. ${ }^{\text {a }}$ del M. (2017): "Modelos de abastecimiento urbano de aguas en la Bética romana: las cisternas". Espacio, Tiempo y Forma. Serie II - Historia Antigua 30: 97-124. http://dx.doi.org/10.5944/ etfii.30.2017.17585

Cespa, S. (2013-2014): Sistemi di approvvigionamento idrico negli insediamenti punico-romani della Sardegna: il caso di Nora. Tese de Doutoramento, Università degli Studi di Milano. Inédita.

Civera i Gómez, M. (2007): "Les cisternes del Castell de Sagunt". Arse 41: 149-186.

Cobos Rodríguez, L. e Iglesias García, L. (2011): “Captación y almacenamiento del agua en el oppidum iberorromano de Zahara de la Sierra (Cádiz)", em L. Lagóstena Barrios; J. Cañizar Palacios e L. Pons Pujol (eds.), Aquam Perducendam Curavit. Captación, uso y administración del agua en las ciudades de la Bética y el Occidente Romano, 347-364. Cádiz, Universidad de Cádiz.

Conlin Hayes, E. (2001): "El abastecimiento de agua en la Carmona Romana”, em A. Caballos Rufino (ed.), Carmona Romana, 213-217. Carmona, Ayuntamiento de Carmona. 
Costa Ribas, B. (2007): "Punic Ibiza under the Roman Republic", em P. van Dommelen e N. Terrenato (eds.), Articulating local cultures. Power and identity under the expanding Roman Republic, 85-102. Portsmouth, Journal of Roman Archaeology.

Cuadrado, E. (1977-1978): “Ungüentarios cerámicos en el mundo Ibérico. Aportación cronológica". Archivo Español de Arqueología 50-51: 389-400.

Delgado, M. (1994): "Notícia sobre cerâmicas de engobe vermelho não vitrificável encontradas em Braga". Cadernos de Arqueologia, Série II, 10-11: 113-149.

Dias, V. (2010): A cerâmica campaniense do Monte Molião, Lagos. Tese de Mestrado, Faculdade de Letras da Universidade de Lisboa. Inédita.

Dias, V. (2015): “A cerâmica campaniense do Monte Molião, Lagos. Os hábitos de consumo no litoral algarvio durante os séculos II a.C. e I a.C.”. Spal 24: 99-128. http://dx.doi.org/10.12795/spal.2015i24.05

Egea Vivancos, A. (2003): “Ingeniería hidráulica en Carthago Nova: las cisternas". Mastia 2: 109-127.

Egea Vivancos, A. (2010): "La cultura del água en Época Ibérica: una visión de conjunto". Lucentum XXIX: 119-138.

Ettlinger, E.; Hedinger, B.; Hoffmann, B.; Kenrick, P.; Pucci, G.; Rothrubi, K.; Schneider, G.; Schnurbein, S.; Wells, C. e Zabehlicky-Scheffeneger, S. (1990): Conspectus Formarum Terrae Sigillatae Italico Modo Confectae. Bonn, Dr. Rudolf Habelt Gmbh.

Erice Lacabe, R. (1995): Las Fíbulas del Nordeste de la Península Ibérica: siglos I a.E. al IV d.E. Zaragoza, Institución "Fernando el Católico".

Fantar, M. (1975): "Le problème de l'eau potable dans le monde phénicien et punique: les citernes". Les Cahiers de Tunisie XXIII, 89-90: 9-18.

Fortes Santos, M..; Carrasco Gómez, I.; Jiménez Hernández, A. e Romero Paredes, C. (2011): “Aproximación arqueológica al yacimiento de Ategua (Córdoba)". Romula 10: 135-198.

García Vargas, E. (2000): “Ánforas romanas producidas en Hispalis. Primeras evidencias arqueológicas". Habis 31: 235-260.

García Vargas, E.; Almeida, R. e González Cesteros, H. (2011): "Los tipos anfóricos del Guadalquivir en el marco de los envases hispanos del siglo I a.C. Un universo heterogéneo entre la imitación y la estandardización”. Spal 20: 185-283. http://dx.doi. org/10.12795/spal.2011.i20.12

García Vargas, E. e López Rosendo, E. (2008): “El alfar de Rabatún (Jerez de la Frontera, Cádiz) y la producción de ánforas y cerámica común en la campiña del Guadalete en época altoimperial romana”. Spal 17: 281-313. http://dx.doi.org/10.12795/spal.2008. i17.12

Girón Anguiozar, L. (2010): “Las cerámicas comunes del alfar romano de Puente Melchor (Puerto Real, Cádiz). Un ensayo de clasificación de las formas abiertas". Herakleion 3: 105-162.

Girón Anguiozar, L. (2017): La cerámica común romana en la Bahía Gaditana en época romana. Alfarería y centros de producción. Oxford, Archaeopress.

Girón Anguiozar, L. e Costa García, J. M. (2009): “La cerámica de imitación de engobe rojo pompeyano en los yacimientos militares romanos peninsulares. Un estado de la cuestión", em Á. Morillo; N. Hanel e E. Martín Hernández (eds.), Limes XX. Estudios sobre la frontera romana (Roman frontier studies): 497512. León, CSIC/ Instituto Histórico Hoffmeyer.

Guerrero Misa, L. (2009): “Construcciones hidráulicas en la ciudad romana de Ocuri (Salto de la Mora, Ubrique)", em L. Lagóstena Barrios e F. Zuleta Alejandro (eds.), La captación, los usos y la administración del agua en Baetica: estudios sobre el abastecimiento hídrico en comunidades cívicas del Conventus Gaditanus: 257-308. Cádiz, Universidad de Cádiz.

Hayes, J. (1972): Late Roman pottery. London, The British School at Rome.

Hilgers, W. (1969): Latenische Gefässnamen. Bezeichnungen Funktion und Form römischer Gefässe nach den antiken Schriftquellen. Dusseldorf, Rheinland-Verlag.

Humphrey, C.; Shutherland, V. e Carson, R. (1994): The Roman Imperial Coinage. X, The Divided Empire and the Fall of the Western Parts. Londres, Spink.

Jiménez Higueras, Mª (2005): "Estudio de un ajuar funerario iberorromano excepcional procedente del Cerro de la Cabeza del Obispo (Alcaudete, Jaén)". Antiquitas 17: 13-31.

Lara Medina, M. (2018): "Sobre el abastecimiento, la distribución y la evacuación hídrica en Gades". Zephyrus LXXXI: 141-163. http://dx.doi. org/10.14201/zephyrus201881141163

Lavado Florido, M. (2004): "El complejo industrial de Puente Melchor: el centro productor, la organización del espacio y su área de influencia”, em D. Bernal Casasola e L. Lagóstena Barrios (eds.), Figlinae Baeticae. Talleres alfareros y producciones cerámicas en la bética romana (ss. II a.C.-VII d.C.): 473487. Cádiz (2003), Oxford, Archaeopress. 
Lézine, A. (1968): Carthage. Utique. Études d'Architecture et d'Urbanisme. Paris, Centre National pour la Recherche Scientifique.

López Castro, J. (2005): “Astarté en Baria. Templo y producción entre los Fenicios Occidentales". Archivo Español de Arqueología 78: 5-21. https://doi. org/10.3989/aespa.2005.v78.71

López de la Orden, M. ${ }^{\text {a }}$ (2003): "Urnas cinerarias de la necrópolis romana de Cádiz”. Anuario Arqueológico de Andalucía 2000 II: 111-116.

López Mullor, A. (1990): Las cerámicas romanas de paredes finas en Cataluña. Zaragoza, Pórtico.

López Rosendo, E. (2008): "El alfar romano altoimperial del Jardín de Cano (El Puerto de Santa María, Cádiz. España), en el contexto económico de Gades". Revista de Historia de El Puerto 41: 39-74.

Lozano Rodríguez, J. A.; Gámez-Layva Hernández,

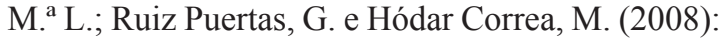
"Denominación, edad y funcionalidad del depósito de agua hallado entre las Calles Álamo del Marqués y San José (Albaicín, Granada)", em A. Adroher Auroux e J. Blánquez Pérez (eds.), Ier Congreso Internacional de Arqueología Ibérica Bastetana: 117130. Baza (2008), Madrid/Granada, Universidad Autónoma de Madrid/ Universidad de Granada.

Marabini, M. ${ }^{\mathrm{a}}$ (1973): The Roman thin walled pottery from Cosa (1948-1954). Roma, American Academy in Rome.

Martínez Rodríguez, F. (1989): "Las cerámicas béticas de imitación tipo Peñaflor: bases para el estudio de un nuevo grupo cerámico de época altoimperial". Boletín de la Asociación de Amigos de la Arqueología 26: 60-65.

Mata Almonte, E. (2009): "Precedentes de los aprovechamientos hídricos en la antigüedad gaditana. El mundo Turdetano", em L. Lagóstena Barrios e F. Zuleta Alejandro (eds.), La captación, los usos y la administración del agua en Baetica: estudios sobre el abastecimiento hídrico en comunidades cívicas del Conventus Gaditanus: 115-170. Cádiz, Universidad de Cádiz.

Mattingly, H.; Sydenham, E.; Sutherland, C. e Carson, R. (1923): The Roman imperial coinage. Vol. I. Londres, Spink.

Mayet, F. (1975): Les Céramiques a Parois Fines dans la Péninsule Ibérique. Paris, Éditions De Boccard.

Mezzolani, A. (2010): "Studi di raccolta idrica a Olbia: dati tipologici, strutturali e topografici sulle cisterne di età púnica”, em M. Milanese; P. Ruggeri e C. Vismara (eds.), L’Africa Romana XVIII. I luoghi e le forme dei mestieri e della produzione nelle province africane: 1761-1776. Olbia (2008), Sassari, Università degli Studi di Sassari.

Montero, R.; Sáez, A.; Montero, A. e Mata, E. (2008): "El alfar romano de El Palomar (El Puerto de Santa María, Cádiz). Estudio preliminar”, em J. P. Bernardes (ed.), Hispania Romana: Actas do IV Congresso de Arqueologia Peninsular: 89-102. Faro, Universidade do Algarve.

Morel, J. P. (1965): Céramique à vernis noir du Forum romain et du Palatin. Paris, Éditions De Boccard.

Morena López, J. A. (2016): “Torreparedones. La campaña de excavación de 2015-2016." Baena Arqueológica 16: 2-15.

Muñóz Vicente, Á. (1987): "Avance sobre el estudio de los ungüentarios helenísticos de Cádiz”. Anuario Arqueológico de Andalucía 1986 II: 520-525.

Niveau de Villedary y Mariñas, A. M. (2003): Las cerámicas gaditanas "tipo Kuass": bases para el análisis de la Bahía de Cádiz en época púnica. Madrid, Real Academia de la Historia.

Olcese, G. (2003): Ceramiche comuni a Roma $e$ in área romana: produzione, circolazione e tecnologia (tarda età repubblicana-prima età imperiale). Mântua, Società archeologica padana.

Olcese, G. (2012): Atlante dei siti di produzione cerámica (Toscana, Lazio, Campania e Sicilia). Roma, Quasar.

Olcina Doménech, M.; Guilabert Mas, A. e Tendero Porras, E. (2010): "Lectura púnica del Tossal de Manises (Alicante)". Mainake XXXII (I): 229-249.

Passelac, M. (1993): "Céramique à parois fines", en Dictionnaire des céramiques antiques (VIIe s. av.n.e.-VII s. d.n.e.) en Méditerranée nord-occidentale, Lattara 6: 511-521.

Pavolini, C. (2000): Scavi di Ostia. La ceramica comune. Le forme in argilla depurata dell'Antiquarium. Roma, Istituto Poligrafico e Zecca dello Stato.

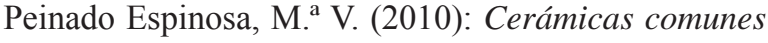
romanas en el Alto Guadalquivir: El alfar de Los Villares de Andújar. Tese de Doutoramento, Universidad de Granada. Inédita.

Pereira, C. (2018): As Necrópoles Romanas Do Algarve. Acerca dos Espaços da Morte no Extremo Sul da Lusitânia. O Arqueólogo Português, Suplemento 9. Lisboa, Museu Nacional de Arqueologia / Imprensa Nacional.

Pereira, C. e Arruda, A. (2016): “As lucernas romanas do Monte Molião (Lagos, Portugal)”. Spal 25: 149181. http://dx.doi.org/10.12795/spal.2016i25.06

Pérez Macías, J. A. (2018): Fortificaciones romanas en el área minera de Huelva. Huelva, Universidad de Huelva. 
Pinto, I. V. (2003): A cerâmica comum das Villae romanas de São Cucufate (Beja). Lisboa, Universidade Lusíada.

Pinto, I. V. e Morais, R. (2007): “Complemento de comércio das ânforas: cerâmica comum bética no território Português", em L. Lágostena, D. Bernal e A. Arévalo (eds.), Actas del Congreso Internacional CETARIAE. Salsas y Salazones de pescado en Occidente durante la Antigüedad: 235-254. Cádiz (2005), Oxford, Archaeopress.

Ponsich, M. e Tarradell, M. (1965): Garum et industries antiques de salaison dans le Méditerranée Occidentale. Paris, Presses Universitaires de France.

Ponte, S. (2006): Corpus signorum das fíbulas protohistóricas e romanas de Portugal. Lisboa, Caleidoscópio.

Prado, G. de (2008): “La gestió de l'aigua a l'oppidum del Puig de Sant Andreu (Ullastret)". Cypsela 17: 185-200.

Protocole Beauvray (1998): "Protocole de quantification des céramiques", em P. Arcelin e M. TufreauLibre (dirs.), La quantification des céramiques. Conditions et protocole: I-XVII. Glux-en-Glenne, Centre Archéologique Européen du Mont Beuvray.

Puertas Tricas, R. (1982): Excavaciones arqueológicas en Lacipo (Casares, Málaga). Campañas de 1975 y 1976. Madrid, Ministerio de Cultura.

Py, M. (1993): "Unguentariums", em Dictionnaire des céramiques antiques (VIIe s. av.n.e.-VII s. de.n.e.) en Méditerranée nord-occidentale, Lattara 6: 581584.

Py, M. (2016): Dictionnaire des objets protohistoriques de Gaule méditerranéenne (IXe - Ier siècles avant notre ère), Lattara 23. Lattes, Association pour le Développement de l'Archéologie en LanguedocRoussillon.

Quercia, A. (2008): "Le ceramiche comuni di età romana", em F. Filippi (coord..), Horti et Sordes. Uno scavo alle falde del Gianicolo: 141-176. Roma, Quasar.

Quesada, F.; Kavanagh, K. e Moralejo, J. (2010): "El asentamiento de época ibérica en el Cerro de la Cruz". Oikos 2: 75-96.

Ramallo Asensio, S. e Martín Camino, M. (2015): "Qart-Hadasht en el marco de la II Guerra Púnica", em J. Bellón, A. Ruiz, M. Molinos, C. Rueda e F. Gómez (eds.), La Segunda Guerra Púnica en la Península Ibérica. Baecula, Arqueología de una Batalla: 129-162. Jaén, Universidad de Jaén.

Ramos Suárez, M. e e García Vargas, E. (2014): “Imitaciones de cerámicas de barniz negro en Hispalis: los materiales del Patio de Banderas del Real Alcázar de Sevilla", em R. Morais, A. Fernández e M. Sousa (eds.), As produções cerâmicas de imitação na Hispânia. Monografias Ex Officina Hispana II: 139-149. Porto, Universidade do Porto.

Revilla, V. e Roca, M. (eds.) (2010): Contextos ceràmics i cultura material d'època augustal a l'occident romà. Barcelona (2007), Barcelona, Universitat de Barcelona.

Ricci, A. (1985): "Ceramica a pareti sottili”, em Atlante delle forme ceramiche II. Ceramica fina romana nel bacino Mediterraneo (tardo Ellenismo e primo Impero): 231-357. Roma, Istituto della Enciclopedia Italiana.

Roca, M. e Principal, J. (2007): Les imitacions de vaixella fina importada a la Hispania Citerior (segles I $a C-I d C$ ). Sèrie Documenta 6. Tarragona, Institut Català d'Arqueologia Clàssica

Roldán, L. (1992): Técnicas constructivas romanas en Carteia (San Roque, Cádiz). Madrid, Universidad Autónoma de Madrid.

Ruiz Acevedo, J. e Delgado Béjar, F. (1991): El agua en las ciudades de la Bética. Écija, Gráficas Sol.

Ruiz, A., Nocete, F. e Zafra, N. (1990): “La excavación arqueológica de urgencia en el Cerro de la Horca, La Guardia, Jaén". Anuario Arqueológico de Andalucía 1987, III: 344-353.

Ruiz Montes, P. e Peinado Espinosa, M. ${ }^{a}$ V. (2012): "Las cerámicas grises bruñidas republicanas en el Alto Guadalquivir o un fenómeno de imitatio hacia fines del Mundo Ibérico. A cuento de un conjunto en el asentamiento iberorromano de Isturgi'. Saguntum 44: 111-126. http://dx.doi.org/10.7203/ SAGVNTVM.44.1798

Sáez Romero, A. (2005): “Aproximación a la tipología de la cerámica común púnico-gadirita de los ss. IIIII". Spal 14: 145-177. http://dx.doi.org/10.12795/ spal.2005.i14.06

Sáez Romero, A. (2008): La producción cerámica en Gadir en época tardopúnica (siglos III/I). Torre Alta: Balance de la investigación y novedades histórico-arqueológicas. Oxford, Archaeopress.

Sánchez, M. ${ }^{a}$ (1992): Cerámica común romana de Mérida (Estudio preliminar). Cáceres, Universidad de Extremadura.

Santrot, M.-H. e Santrot, J. (1979): Céramiques Communes Gallo-Romaines d'Aquitanie. Paris, Centre National de la Recherche Scientifique.

Serrano Ramos, E.. (2000): Cerámica Común Romana: siglos II a.C. al VII d.C. Materiales importados y de producción local en el territorio malacitano. Málaga, Universidad de Málaga. 
Silva, C. T da (1996): "Produção de ânforas na área urbana de Setúbal: a oficina romana do Largo da Misericórdia", em G. Filipe e J. Raposo (eds.), Ocupação romana dos estuários do Tejo e do Sado. Actas das Primeiras Jornadas sobre Romanização dos Estuários do Tejo e do Sado: 43-54. Seixal (1995), Lisboa/Seixal, Dom Quixote/Câmara Municipal do Seixal.

Sotomayor Muro, M.; Pérez Casas, A. e Roca Roumens, M. (1976): "Los alfares romanos de Andújar (Jaén): Dos nuevas campañas". Noticiario Arqueológico Hispánico 4: 111-147.

Sousa, E. e Arruda, A. (2014): “A cerâmica comum romano-republicana de Monte Molião (Lagos)". Onoba 2: 55-90.

Sousa, E. e Arruda, A. (2018): “A Cerâmica de Paredes Finas de Monte Molião (Lagos, Portugal)". CuPAUAM 44: 201-226. http://doi.org/10.15366/cupauam2018.44.011

Sutherland, H. e Carson, R. (1984): The Roman Imperial Coinage. I. Augustus-Vitellius (31 BC-69 AD). Londres, Spink.

Vaquerizo Gil, D. (1990): "Excavación arqueológica sistemática "Cerro de la Cruz" (Almedinilla,
Córdoba). Campaña de 1987. Memória provisional". Anuario Arqueológico de Andalucía 1987, II: 281-290.

Vázquez Paz, J.; García Vargas, E.; Maestre Borge, C. e Arnold, E. (2018): “Contextos cerámicos de Hispalis c. 50 a.C. al 225 d.C. Excavaciones arqueológicas en el Patio de Banderas del Real Alcázar de Sevilla (2012-2014)", em P. Ruiz Montes, M. ${ }^{\mathrm{a}}$ V. Peinado Espinosa e M. ${ }^{\mathrm{a}}$ Fernández García (eds.), Estudios para la configuración de las facies cerámicas altoimperiales en el Sur de la Península Ibérica: 129-155. Oxford: Archaeopress.

Viegas, C. (2011): A ocupação romana do Algarve. Estudo do povoamento e economia do Algarve central e oriental no período romano. Lisboa, UNIARQ.

Villaronga, L. (1994): Corpus nummum Hispaniae ante augusti aetatem. Madrid, José A. Herrero.

Webb, P. (1968): The Roman Imperial Coinage. V/1. Valerian to Florian. Londres, Spink.

Wilson, A. (2001): "Water supply in ancient Carthage", em Carthage papers: The early colony's economy, water supply, a private bath, and the mobilization of state olive oil: 65-102. Portsmouth, Journal of Roman Archaeology. 